\title{
Trans-Himalayan transport of organochlorine compounds: three- year observations and model-based flux estimation
}

\author{
Ping Gong ${ }^{1,2}$, Xiaoping Wang ${ }^{1,2,6^{*}}$, Balram Pokhrel ${ }^{1,4}$, Hailong Wang ${ }^{5}$, Xiande Liu ${ }^{7}$, \\ Xiaobo Liu ${ }^{1,3}$, Frank Wania ${ }^{8}$
}

${ }^{1}$ Key Laboratory of Tibetan Environmental Changes and Land Surface Process, Institute of Tibetan Plateau Research, Chinese Academy of Sciences, Beijing 100101, China

${ }^{2}$ CAS Center for Excellence in Tibetan Plateau Earth Sciences, Beijing 100101, China

${ }^{3}$ Kathmandu Center for Research and Education, CAS-TU, Kathmandu 44618, Nepal

${ }^{4}$ School of Science, Kathmandu University, Dhulikhel 45200, Nepal

${ }^{5}$ Atmospheric Sciences and Global Change Division, Pacific Northwest National Laboratory (PNNL), Richland, WA 99352, USA

${ }^{6}$ University of Chinese Academy of Sciences, Beijing 100049, China

${ }^{7}$ Chinese Research Academy of Environmental Sciences, Beijing 100012, China

8 University of Toronto Scarborough, Department of Physical and Environmental Sciences, 1265 Military Trail, Toronto, ON, Canada, M1C 1A4

*Corresponding Author

Tel: +86-10-84097102

Fax: +86-10-84097079

E-mail: wangxp@itpcas.ac.cn 


\section{Catalog}

$\begin{array}{lll}\text { Table S1 Detailed information about the sampling sites } & \text { S4 }\end{array}$

Table S2 Climatological conditions of the sampling sites during monsoon/non- S5 monsoon seasons and the sampling rates of XAD-PAS for each site

Text S1 Procedures for analyzing OCPs and PCBs S6

Table S3 The concentrations of target compounds in field blanks and limits of S7 detection

Table S4 Relative percent difference of duplicate PASs

Table S5 Concentrations of the target compounds in XAD columns

Table S6 Calculated volumetric concentrations of target compounds in air

S11-S12

Text S2 Air-mass trajectories from/to the sampling sites during seasons $\quad$ S13

Figure S1 Forward trajectories of air masses from sampling sties to downwind regions during the monsoon season

Figure S2 Forward trajectories of air masses from sampling sties to downwind regions during the non-monsoon season

Figure S3 Backward trajectories of the receptor sites on the northern slope of the Himalayas

Figure S4 Transects and sampling sites simulated with the MCMPOP model

Figure S5 Relative deviations of the atmospheric POP concentrations between years to the average concentrations

Text S3 Description of the Multi-Compartment Mountain POP (MCMPOP) model

Text S3-2 Main modules of model

Text S3-3 Calculation of concentrations, pool, and fluxes $\quad$ S23

Table S7 Values and equations of physicochemical properties for compounds

Table S8 Equation of Z-values and related parameters

Table S9 Equation of D-values and related parameters

Table S10 Lists of parameters in the mass balance equations

Figure S6 Average absolute concentrations of five seasonal samples and relative composition of target pollutants in the atmosphere along the transect from low-land to high-altitude regions in the Himalayas.

Figure S7 Seasonal variations of atmospheric POP concentrations and changes in the Indian monsoon index during the sampling periods

Figure S8 The ratios of concentrations during the monsoon seasons to those during the non-monsoon seasons 
Figure S9 Observed and simulated concentrations of atmospheric POPs along the

Himalayan slope transect from Syabru Besi to the Xixiabangma during the monsoon season

Figure S10 Observed and simulated concentrations of atmospheric POPs along the Himalayan slope transect from Syabru Besi to the Xixiabangma during the nonmonsoon season

Figure S11 Comparison between simulated and observed concentrations of organochlorine compounds in air, soil, and foliage along the southern slope of the Himalayas

Figure S12 Comparison between simulated and observed atmospheric concentrations on the northern slope of the Himalayas

Text S4. Model evaluation

Text S4-1 Comparisons between the observed and the simulated values

Text S4-2 Uncertainties of the model

Table S11 Sensitivity analysis of selected parameters in the model

Figure S13 Exchange fluxes of target pollutants for the atmospheric processes simulated by the MCMPOP model (non-monsoon season, on the slopes)

Figure S14 Changes in the fluxes of HCB along the slopes of the Himalayas

Figure S15 Average stored amount of POPs and percentages in different matrices

Figure S16 The simulated atmospheric transport fluxes from one cell to the next upslope

Figure S17 Simulated atmospheric concentrations of organochlorine compounds along the Gillon valley during the monsoon season

Figure S18 Simulated atmospheric concentrations of organochlorine compounds along the Gillon valley during the non-monsoon season

Figure S19 Exchange fluxes of target pollutants for the atmospheric processes simulated by the MCMPOP model (monsoon season, along the Gillon valley)

Figure S20 Exchange fluxes of target pollutants for the atmospheric processes simulated by the MCMPOP model (non-monsoon season, along the Gillon valley)

Figure S21 Changes in the fluxes of HCB along the Gillon valley

Figure S22 The mountain ridge and the main river valleys in the Himalayas

Table S12 Details of the river valleys across the Himalayas

Text S5 Estimation and uncertainties of the annual total transport of atmospheric POPs across the Himalayas

Table S13 The contributors for the field and data analysis work in this study 
Table S1. Detailed information about the sampling sites

\begin{tabular}{|c|c|c|c|c|c|c|c|c|c|c|}
\hline Location & Longitude & Latitude & $\begin{array}{l}\text { Altitud } \\
\text { /m }\end{array}$ & \multicolumn{2}{|l|}{ Type of land use } & \multicolumn{5}{|c|}{ Date of setting up PAS or changing XAD-filled cylinders } \\
\hline \multicolumn{11}{|c|}{ Southern slope of the Himalayas } \\
\hline Simara & $\mathrm{E} 84^{\circ} 58^{\prime} 48.13^{\prime \prime}$ & $\mathrm{N} 27^{\circ} 9^{\prime} 51.42^{\prime \prime}$ & 135 & Farmland/forest & 2012.05.21 & 2012.10.24 & 2013.04.29 & 2013.11.20 & 2014.05.19 & 2014.11.13 \\
\hline Hetauda & $\mathrm{E} 85^{\circ} 01^{\prime} 57.22^{\prime \prime}$ & $\mathrm{N} 27^{\circ} 25^{\prime} 49.19^{\prime \prime}$ & 470 & Downtown & & & & & 2014.05 .20 & 2014.11.13 \\
\hline Kathmandu & $\mathrm{E} 85^{\circ} 17^{\prime} 15.90^{\prime \prime}$ & $\mathrm{N} 27^{\circ} 40^{\prime} 57.66^{\prime \prime}$ & 1330 & Urban & 2012.05.24 & 2012.11.07 & 2013.04.28 & 2013.11.19 & 2014.05.15 & 2014.11.23 \\
\hline Syapru Besi & $\mathrm{E} 85^{\circ} 20^{\prime} 11.40^{\prime \prime}$ & $\mathrm{N} 28^{\circ} 9^{\prime} 46.92^{\prime \prime}$ & 1475 & Forest & 2012.05.06 & 2012.10.26 & 2013.05.02 & 2013.11.08 & 2014.05 .23 & 2014.11.14 \\
\hline Daman & $\mathrm{E} 85^{\circ} 5^{\prime} 34.07^{\prime \prime}$ & $\mathrm{N} 27^{\circ} 36^{\prime} 16.04^{\prime \prime}$ & 2280 & $\begin{array}{l}\text { Remote } \\
\text { regions/forest }\end{array}$ & 2012.05.23 & 2012.10.25 & 2013.04.29 & 2013.11.20 & 2014.05 .20 & 2014.11.13 \\
\hline Richhe & $\mathrm{E} 85^{\circ} 25^{\prime} 16.02^{\prime \prime}$ & $\mathrm{N} 28^{\circ} 10^{\prime} 31.74^{\prime \prime}$ & 2780 & Forest & 2012.05.07 & 2012.10.27 & 2013.05.03 & 2013.11.09 & 2014.05.24 & 2014.11.15 \\
\hline Kyanjin Gumba & $\mathrm{E} 85^{\circ} 34^{\prime} 55.56^{\prime \prime}$ & $\mathrm{N} 28^{\circ} 12^{\prime} 42.44^{\prime \prime}$ & 3850 & Brushwood/grass & 2012.05.09 & 2012.10.29 & 2013.05.05 & 2013.11.11 & 2014.05.26 & 2014.11.17 \\
\hline Yala Peak & $\mathrm{E} 85^{\circ} 36^{\prime} 35.14^{\prime \prime}$ & $\mathrm{N} 28^{\circ} 13^{\prime} 56.89^{\prime \prime}$ & 5100 & $\begin{array}{l}\text { End of glacier } \\
\text { /bare land }\end{array}$ & 2012.05.10 & 2012.11.01 & 2013.05.07 & 2013.11.13 & 2014.05 .27 & 2014.11.18 \\
\hline \multicolumn{11}{|c|}{ Northern slope of the Himalayas } \\
\hline Xixiabangma & $\mathrm{E} 85^{\circ} 48^{\prime} 17.24^{\prime \prime}$ & $\mathrm{N} 28^{\circ} 23^{\prime} 19.06^{\prime \prime}$ & 5806 & End of glacier & 2012.09.29 & & 2013.08.15 & & & \\
\hline Gillon* & $\mathrm{E} 85^{\circ} 23^{\prime} 41.94^{\prime \prime}$ & $\mathrm{N} 28^{\circ} 33^{\prime} 27.50^{\prime \prime}$ & 4500 & Rural site & & & 2012 & 2014 & & \\
\hline
\end{tabular}

*these data were derived from Wang et al. ${ }^{1}$ 
Table S2. Climatological conditions of the sampling sites during monsoon/non-monsoon seasons and the sampling rates (PSR) of XAD-PAS for each site

\begin{tabular}{|c|c|c|c|c|c|c|c|}
\hline & $\begin{array}{l}\text { Altitude } \\
\text { (m) }\end{array}$ & $\begin{array}{c}\text { Temperature } \\
\left(T,{ }^{\circ} \mathrm{C}\right)\end{array}$ & $\begin{array}{l}\text { Wind speed } \\
(v, \mathrm{~m} / \mathrm{s})\end{array}$ & $\begin{array}{l}\text { Air pressure } \\
\quad(P, \mathrm{hPa})\end{array}$ & $\begin{array}{l}\text { Precipitation } \\
\quad(P r, \mathrm{~mm})\end{array}$ & $T^{1.75} / P$ & $\begin{array}{c}P S R^{\mathrm{i}} \\
\text { (m²/day) }\end{array}$ \\
\hline \multicolumn{8}{|c|}{ Monsoon season } \\
\hline Simara ${ }^{\text {a }}$ & 135 & 29.2 & 1.6 & 1153 & 1500 & 19.0 & 0.5 \\
\hline Hetauda $^{\text {b }}$ & 470 & 26.8 & 2.0 & 1111 & 1550 & 19.5 & 0.8 \\
\hline Kathmandu $^{\text {a }}$ & 1330 & 22.9 & 3.1 & 1003 & 1000 & 21.1 & 2.7 \\
\hline Syapru Besi ${ }^{c}$ & 1475 & 17.6 & 2.1 & 1009 & 894 & 20.3 & 0.9 \\
\hline Daman $^{d}$ & 2280 & 17.9 & 3.3 & 995 & & 20.4 & 3.0 \\
\hline Richhe $^{\mathrm{e}}$ & 2780 & 13.1 & 1.2 & 905 & 735 & 22.0 & 0.5 \\
\hline Kyanjin Gumba ${ }^{\mathrm{f}}$ & 3850 & 7.7 & 3.0 & 640 & 557 & 30.1 & 5.2 \\
\hline Yala Peak ${ }^{g}$ & 5100 & 1.1 & 2.2 & 550 & 1198 & 33.6 & 2.9 \\
\hline \multicolumn{8}{|c|}{ Non-monsoon season } \\
\hline Simara $^{\mathrm{a}}$ & 135 & 20.4 & 1.0 & 1114 & & 18.7 & 0.3 \\
\hline Kathmandu ${ }^{\text {a }}$ & 1330 & 14.3 & 2.0 & 1000 & 150 & 20.1 & 0.9 \\
\hline Syapru Besi ${ }^{\mathrm{c}}$ & 1475 & 11.0 & 1.7 & 1003 & 175 & 19.6 & 0.6 \\
\hline Daman $^{\mathrm{d}}$ & 2280 & 9.4 & 2.0 & 989 & & 19.7 & 0.8 \\
\hline Richhe $^{\mathrm{e}}$ & 2780 & 5.6 & 1.0 & 896 & 200 & 21.2 & 0.4 \\
\hline Kyanjin Gumba ${ }^{\mathrm{f}}$ & 3850 & 0.1 & 3.0 & 637 & 205 & 28.8 & 5.0 \\
\hline Yala Peak ${ }^{g}$ & 5100 & -8.0 & 3.0 & 546 & 183 & 31.9 & 5.7 \\
\hline \multicolumn{8}{|c|}{ Whole year } \\
\hline Mt. Xixiabangma ${ }^{\text {h }}$ & 5806 & -14.6 & 8.7 & 495 & 660 & 33.7 & 39.6 \\
\hline \multicolumn{8}{|c|}{ b: derived from Pokhrel et al. (2018) ${ }^{2}$} \\
\hline \multicolumn{8}{|c|}{ c: estimated based on the data derived from Dong et al.(2017) ${ }^{3}$} \\
\hline \multicolumn{8}{|c|}{ d: linear interpolation according to elevation } \\
\hline \multicolumn{8}{|c|}{ e: calculated based on the data of Shrestha (2013) } \\
\hline \multicolumn{8}{|c|}{ f: Data of automatic weather station (download from Third Pole Environment Database, tpedatabase.cn) } \\
\hline \multicolumn{8}{|c|}{ g: Download from Regional Database System of International Centre for Integrated Mountain Development (ICIMOD, rds.icimod.org) } \\
\hline \multicolumn{8}{|c|}{ h: derived from Li et al. $(2011)^{5}$} \\
\hline i: calculated by equat & & & & & & & \\
\hline
\end{tabular}




\section{Text S1. Procedures for analyzing OCPs and PCBs.}

The XAD samples were transferred into a Soxhlet apparatus and spiked with a mixture of surrogate standards (PCB-30 and Mirex). Samples were Soxhlet extracted using DCM for 24 hours. The extracts were first concentrated by a rotary evaporator and then solventexchanged into hexane. Then, the samples were loaded on the top of a chromatography column (consisting of, from the top to the bottom: $1 \mathrm{~g}$ of anhydrous sodium sulfate, $2 \mathrm{~g}$ of $3 \%$ deactivated alumina, and $3 \mathrm{~g}$ of $6 \%$ deactivated silica gel), and eluted with a $30 \mathrm{~mL}$ mixture of DCM and hexane (1:1). The analyte was further cleaned by gel permeation chromatography (GPC, containing $6 \mathrm{~g}$ of Biobeads SX3) to remove any remaining lipids and then to yield the OCP and PCB fractions. Finally, the fraction was solvent-exchanged and concentrated to $20 \mu \mathrm{L}$ in dodecane containing a known quantity of pentachloronitrobenzene (PCNB) and PCB-209 as the internal standards.

All samples and blanks were analyzed on a gas chromatograph (GC) with an ion-trap mass spectrometer (MS) (Finnigan Trace GC/PolarisQ), using a CP-Sil 8CB capillary column (50 m, $0.25 \mathrm{~mm}, 0.25 \mu \mathrm{m}$ ), operating in MS-MS mode. Helium was used as the carrier gas at $1 \mathrm{~mL} \mathrm{~min}{ }^{-1}$ under constant-flow mode. The oven temperature was first held at $100{ }^{\circ} \mathrm{C}$ for $2 \mathrm{~min}$, and was then ramped at a rate of $20^{\circ} \mathrm{C} \mathrm{min}^{-1}$ to $140^{\circ} \mathrm{C}$, at $4^{\circ} \mathrm{C} \mathrm{min}^{-1}$ to $200^{\circ} \mathrm{C}$ with a $10 \mathrm{~min}$ hold time, and then at $4^{\circ} \mathrm{C} \mathrm{min}^{-1}$ to $300^{\circ} \mathrm{C}$ ( 2 min hold time). 
Table S3. The concentrations of target compounds in field blanks (ng/sample) and limits of detection

\begin{tabular}{|c|c|c|c|c|c|c|c|c|c|c|c|c|c|c|c|c|}
\hline & \multicolumn{3}{|c|}{$\begin{array}{l}2012 \text { monsoon season } \\
\text { (M12) }\end{array}$} & \multicolumn{3}{|c|}{$\begin{array}{c}2012-2013 \\
\text { non-monsoon season } \\
(\mathrm{N} 13) \\
\end{array}$} & \multicolumn{3}{|c|}{$\begin{array}{l}2013 \text { monsoon season } \\
\text { (M13) }\end{array}$} & \multicolumn{3}{|c|}{$\begin{array}{c}2013-2014 \\
\text { non-monsoon season } \\
\text { (N14) }\end{array}$} & \multicolumn{3}{|c|}{$\begin{array}{l}2014 \text { monsoon season } \\
\text { (M14) }\end{array}$} & \multirow{2}{*}{$\begin{array}{c}\begin{array}{c}\text { Southern } \\
\text { slope }\end{array} \\
\text { LOD }\end{array}$} \\
\hline & Mean $^{\mathrm{a}}$ & $\mathrm{STD}^{\mathrm{b}}$ & $\mathrm{LOD}^{c}$ & Mean & STD & LOD & Mean & STD & LOD & Mean & STD & LOD & Mean & STD & LOD & \\
\hline$\alpha-\mathrm{HCH}$ & 0.04 & 0.01 & 0.08 & 0.10 & 0.03 & 0.19 & 0.25 & 0.06 & 0.42 & 0.02 & 0.02 & 0.10 & 0.12 & 0.12 & 0.12 & 0.08 \\
\hline$\beta-\mathrm{HCH}$ & 0.03 & 0.00 & 0.03 & 0.01 & 0.00 & 0.01 & 0.005 & 0.002 & 0.01 & 0.00 & 0.00 & 0.00 & 0.05 & 0.00 & 0.05 & 0.05 \\
\hline$\gamma-\mathrm{HCH}$ & 0.04 & 0.00 & 0.04 & 0.04 & 0.01 & 0.06 & 0.03 & 0.01 & 0.06 & 0.03 & 0.01 & 0.06 & 0.02 & 0.01 & 0.05 & 0.02 \\
\hline HCB & 0.68 & 0.07 & 0.90 & 0.83 & 0.04 & 0.97 & 0.82 & 0.17 & 1.32 & 0.00 & 0.00 & 0.00 & 1.62 & 0.00 & 1.62 & 0.44 \\
\hline$o, p^{\prime}-\mathrm{DDE}$ & 0.001 & 0.001 & 0.004 & 0.004 & 0.001 & 0.007 & 0.006 & 0.004 & 0.017 & 0.07 & 0.00 & 0.07 & 0.07 & 0.00 & 0.07 & 0.04 \\
\hline$p, p^{\prime}-\mathrm{DDE}$ & 0.08 & 0.04 & 0.14 & 0.005 & 0.001 & 0.008 & 0.07 & 0.05 & 0.20 & 0.10 & 0.00 & 0.10 & 0.21 & 0.04 & 0.32 & 0.09 \\
\hline$o, p^{\prime}-\mathrm{DDD}$ & 0.03 & 0.05 & 0.18 & 0.01 & 0.00 & 0.02 & 0.03 & 0.02 & 0.09 & 0.02 & 0.00 & 0.02 & 0.06 & 0.00 & 0.06 & 0.02 \\
\hline$p, p^{\prime}-\mathrm{DDD}$ & 0.07 & 0.03 & 0.15 & 0.07 & 0.01 & 0.10 & 0.08 & 0.06 & 0.27 & 0.04 & 0.00 & 0.04 & 0.01 & 0.002 & 0.015 & 0.02 \\
\hline$o, p^{\prime}-\mathrm{DDT}$ & 0.41 & 0.21 & 1.03 & 0.15 & 0.01 & 0.18 & 0.06 & 0.06 & 0.25 & 0.23 & 0.00 & 0.23 & 0.08 & 0.01 & 0.11 & 0.10 \\
\hline$p, p^{\prime}-\mathrm{DDT}$ & 0.03 & 0.04 & 0.15 & 0.03 & 0.003 & 0.021 & 0.08 & 0.04 & 0.20 & 0.07 & 0.00 & 0.07 & 0.10 & 0.02 & 0.16 & 0.08 \\
\hline PCB-28 & 0.04 & 0.003 & 0.026 & 0.02 & 0.01 & 0.04 & 0.01 & 0.00 & 0.01 & 0.00 & 0.00 & 0.00 & 0.11 & 0.00 & 0.11 & 0.03 \\
\hline PCB-52 & 0.003 & 0.001 & 0.006 & 0.006 & 0.001 & 0.01 & 0.02 & 0.00 & 0.02 & 0.00 & 0.00 & 0.00 & 0.01 & 0.00 & 0.01 & 0.02 \\
\hline PCB-101 & 0.004 & 0.002 & 0.011 & 0.01 & 0.005 & 0.02 & 0.02 & 0.00 & 0.02 & 0.00 & 0.00 & 0.00 & 0.04 & 0.01 & 0.06 & 0.03 \\
\hline PCB-118 & 0.03 & 0.00 & 0.04 & 0.01 & 0.00 & 0.01 & 0.01 & 0.00 & 0.01 & 0.08 & 0.08 & 0.33 & 0.01 & 0.00 & 0.01 & 0.01 \\
\hline PCB-153 & 0.00 & 0.00 & 0.01 & 0.01 & 0.00 & 0.01 & 0.00 & 0.00 & 0.01 & 0.001 & 0.000 & 0.01 & 0.00 & 0.00 & 0.00 & 0.005 \\
\hline PCB-138 & 0.01 & 0.001 & 0.01 & 0.02 & 0.01 & 0.04 & 0.01 & 0.00 & 0.01 & 0.01 & 0.00 & 0.01 & 0.01 & 0.00 & 0.01 & 0.00 \\
\hline PCB-180 & 0.00 & 0.00 & 0.01 & 0.00 & 0.00 & 0.01 & 0.01 & 0.00 & 0.01 & 0.0 & 0.00 & 0.02 & 0.00 & 0.00 & 0.00 & 0.00 \\
\hline
\end{tabular}

${ }^{a}$ : Mean, the average concentration of the field blanks

b: STD, standard deviations of the field blanks

c: LOD, limits of detection. LOD $=$ Mean $+3 *$ STD 
Table S4. Relative percent difference of duplicate PASs

\begin{tabular}{cccc}
\hline & Simara & Kathmandu & Yala Peak \\
\hline$\alpha$-HCH & $24 \%$ & $16 \%$ & $21 \%$ \\
$\beta$-HCH & $31 \%$ & $25 \%$ & \\
$\gamma$-HCH & $3 \%$ & $23 \%$ & $22 \%$ \\
HCB & $7 \%$ & $2 \%$ & $17 \%$ \\
$o, p^{\prime}-\mathrm{DDE}$ & $44 \%$ & $32 \%$ & $33 \%$ \\
$p, p^{\prime}-\mathrm{DDE}$ & $33 \%$ & $22 \%$ & $24 \%$ \\
$o, p^{\prime}-\mathrm{DDD}$ & & $21 \%$ & $22 \%$ \\
p,p'-DDD & $28 \%$ & $38 \%$ & $8 \%$ \\
$o, p^{\prime}-\mathrm{DDT}$ & $44 \%$ & $2 \%$ & $26 \%$ \\
$p, p^{\prime}-\mathrm{DDT}$ & & $15 \%$ & $21 \%$ \\
PCB-28 & $17 \%$ & $27 \%$ & \\
PCB-52 & $0 \%$ & $10 \%$ & \\
PCB-101 & $41 \%$ & $34 \%$ & \\
\hline
\end{tabular}


Table S5. Concentrations of the target compounds in XAD columns (ng/sample)

\begin{tabular}{|c|c|c|c|c|c|c|c|c|c|c|c|c|c|c|c|c|c|c|c|}
\hline Seasons & Sampling sites & Days & $\alpha-\mathrm{HCH}$ & $\beta-\mathrm{HCH}$ & $\gamma-\mathrm{HCH}$ & НСВ & $o, p^{\prime}-\mathrm{DDE}$ & $p, p^{\prime}-\mathrm{DDE}$ & $o, p^{\prime}-\mathrm{DDD}$ & $p, p^{\prime}-\mathrm{DDD}$ & $o, p$ '-DDT & $p, p^{\prime}$-DDT & PCB-28 & PCB-52 & PCB-101 & PCB-118 & PCB-153 & PCB-138 & PCB-180 \\
\hline \multirow[t]{7}{*}{ M12 } & Simara & 156 & 3.8 & 0.20 & 1.2 & 6.4 & 0.70 & 8.3 & 2.3 & 3.2 & 8.2 & 11 & BDL* & 0.090 & 0.10 & 0.12 & 0.042 & 0.039 & BDL \\
\hline & Kathmandu & 167 & 2.9 & 0.16 & 1.7 & 4.1 & 0.23 & 1.5 & 0.43 & 0.52 & 2.2 & 3.2 & 0.63 & 0.29 & 0.23 & 0.087 & 0.071 & 0.062 & 0.036 \\
\hline & Syapru Besi & 173 & 2.9 & 0.14 & 1.4 & 4.1 & 0.060 & 0.86 & 0.085 & 0.15 & 1.0 & 1.8 & 0.20 & 0.083 & 0.12 & 0.15 & 0.040 & 0.033 & 0.025 \\
\hline & Daman & 155 & 3.2 & 0.14 & 0.42 & 4.3 & 0.51 & 2.0 & 0.54 & 0.87 & 3.5 & 4.5 & BDL & 0.071 & 0.073 & 0.097 & 0.042 & 0.023 & BDL \\
\hline & Richhe & 173 & 1.6 & 0.040 & 0.37 & 3.5 & BDL & 0.16 & 0.16 & 0.18 & 0.91 & 1.8 & 0.080 & 0.038 & 0.076 & 0.053 & 0.019 & 0.011 & 0.011 \\
\hline & Kyanjin Gumba & 173 & 3.2 & 0.087 & 0.55 & 8.1 & 0.0057 & BDL & 0.31 & 0.18 & 2.0 & 1.3 & 0.084 & 0.052 & 0.050 & 0.031 & 0.019 & BDL & BDL \\
\hline & Yala Peak & 175 & 1.4 & BDL & 0.29 & 5.0 & BDL & BDL & 0.16 & BDL & 0.62 & 0.66 & BDL & 0.016 & 0.020 & 0.037 & BDL & BDL & BDL \\
\hline \multirow[t]{7}{*}{ N13 } & Simara & 187 & 1.2 & 0.10 & 1.2 & 6.0 & 0.18 & 1.2 & 0.28 & 0.87 & 1.9 & 2.8 & 0.13 & BDL & 0.020 & 0.030 & 0.010 & BDL & BDL \\
\hline & Kathmandu & 172 & 1.3 & 0.11 & 1.4 & 6.3 & 0.16 & 0.86 & 0.21 & 0.28 & 0.57 & 0.81 & 0.63 & 0.21 & 0.14 & 0.11 & 0.021 & 0.019 & BDL \\
\hline & Syapru Besi & 188 & 1.8 & 0.13 & 1.1 & 8.2 & 0.17 & 0.86 & 0.20 & 0.29 & 1.4 & 0.74 & 0.14 & 0.027 & 0.023 & 0.014 & BDL & BDL & BDL \\
\hline & Daman & 186 & 0.88 & 0.058 & 0.31 & 6.3 & 0.16 & 0.54 & 0.27 & 0.43 & 1.4 & 1.1 & 0.042 & BDL & BDL & BDL & 0.17 & BDL & BDL \\
\hline & Richhe & 188 & 1.5 & 0.12 & 0.51 & 11 & 0.015 & 0.0091 & BDL & BDL & 0.19 & 0.10 & 0.27 & 0.028 & BDL & BDL & BDL & BDL & BDL \\
\hline & Kyanjin Gumba & 188 & 0.23 & 0.018 & 0.12 & 5.7 & 0.046 & 0.21 & 0.029 & BDL & 0.44 & 0.18 & 0.063 & BDL & BDL & 0.015 & BDL & BDL & BDL \\
\hline & Yala Peak & 187 & 0.20 & 0.020 & 0.15 & 7.9 & BDL & BDL & 0.023 & BDL & 0.23 & 0.066 & BDL & BDL & 0.020 & BDL & BDL & BDL & BDL \\
\hline \multirow[t]{7}{*}{ M13 } & Simara & 205 & 3.4 & 0.26 & 1.2 & 11 & 0.33 & 3.1 & 0.85 & 2.0 & 5.3 & 5.3 & 0.38 & 0.15 & 0.044 & BDL & 0.019 & 0.020 & BDL \\
\hline & Kathmandu & 205 & 2.4 & 0.13 & 1.6 & 7.7 & 0.32 & 1.3 & 0.57 & 0.74 & 2.9 & 1.8 & 0.75 & 0.32 & 0.14 & 0.018 & 0.037 & 0.037 & BDL \\
\hline & Syapru Besi & 190 & 2.8 & 0.028 & 1.4 & 8.8 & 0.25 & 1.3 & 0.30 & 0.42 & 3.3 & 2.4 & 0.14 & 0.078 & 0.092 & 0.011 & 0.023 & 0.032 & BDL \\
\hline & Daman & 205 & 2.9 & 0.92 & 0.33 & 4.7 & 0.16 & 0.58 & 0.099 & 0.33 & 1.5 & 1.8 & 0.18 & 0.050 & 0.070 & BDL & BDL & 0.021 & BDL \\
\hline & Richhe & 190 & 0.67 & BDL & 0.20 & 3.6 & 0.034 & 0.30 & 0.32 & 0.23 & 0.81 & 0.21 & 0.016 & 0.035 & 0.026 & BDL & BDL & BDL & BDL \\
\hline & Kyanjin Gumba & 192 & 0.45 & BDL & 0.16 & 6.3 & 0.049 & 0.48 & 0.29 & 0.17 & 1.2 & 0.29 & 0.025 & 0.043 & 0.047 & BDL & BDL & 0.012 & BDL \\
\hline & Yala Peak & 190 & 0.55 & BDL & 0.070 & 7.2 & 0.053 & 0.20 & 0.36 & 0.15 & 0.81 & 0.21 & BDL & 0.022 & 0.028 & BDL & BDL & BDL & BDL \\
\hline \multirow[t]{4}{*}{ N14 } & Simara & 180 & 2.2 & 0.076 & 1.8 & 20 & 0.54 & 3.3 & 0.61 & 1.5 & 3.8 & 2.5 & 0.46 & 0.18 & 0.14 & BDL & BDL & 0.013 & BDL \\
\hline & Kathmandu & 177 & 1.7 & 0.26 & 1.9 & 11 & 0.19 & 0.84 & 0.088 & 0.075 & 0.54 & 0.11 & 0.78 & 0.34 & 0.24 & BDL & BDL & 0.041 & BDL \\
\hline & Syapru Besi & 196 & 1.6 & 0.28 & 1.2 & 11 & 0.10 & 0.64 & 0.056 & 0.058 & 0.40 & BDL & 0.29 & 0.14 & 0.15 & BDL & BDL & BDL & BDL \\
\hline & Daman & 181 & 1.7 & 0.39 & 0.28 & 4.8 & 0.14 & 0.87 & BDL & 0.16 & 0.85 & 0.61 & 0.12 & 0.056 & 0.11 & BDL & BDL & 0.023 & BDL \\
\hline
\end{tabular}




\begin{tabular}{|c|c|c|c|c|c|c|c|c|c|c|c|c|c|c|c|c|c|c|c|}
\hline & Richhe & 196 & 0.61 & 0.059 & 0.10 & 6.18 & 0.055 & 0.31 & BDL & BDL & 0.24 & BDL & 0.29 & 0.062 & 0.055 & BDL & BDL & BDL & BDL \\
\hline & Kyanjin Gumba & 196 & 0.34 & BDL & 0.090 & 3.5 & 0.061 & 0.15 & 0.024 & 0.30 & 0.33 & 0.16 & BDL & BDL & BDL & BDL & 0.0023 & BDL & BDL \\
\hline & Yala Peak & 196 & 0.16 & BDL & 0.099 & 4.1 & 0.069 & 0.11 & 0.043 & 0.25 & 0.36 & 0.072 & BDL & BDL & BDL & BDL & 0.0041 & BDL & BDL \\
\hline \multirow[t]{8}{*}{ M14 } & Simara & 188 & 2.5 & 0.30 & 0.86 & 6.4 & 2.0 & 12 & 2.5 & 4.5 & 9.5 & 8.9 & 1.4 & BDL & 0.37 & 0.47 & 0.063 & BDL & 0.030 \\
\hline & Hetauda & 178 & 4.2 & 0.48 & 3.5 & 7.2 & 5.1 & 73 & 2.6 & 9.3 & 13 & 24 & 0.78 & 0.42 & 0.32 & 0.089 & 0.076 & BDL & 0.013 \\
\hline & Kathmandu & 192 & 2.0 & 0.080 & 2.2 & 6.3 & 0.63 & 1.9 & 1.0 & 0.31 & 1.2 & 1.8 & 0.86 & 0.13 & 0.48 & 0.11 & 0.046 & 0.043 & 0.013 \\
\hline & Syapru Besi & 175 & 2.4 & 0.43 & 1.5 & 7.2 & 0.25 & 1.3 & 0.50 & 0.32 & 1.4 & 0.77 & 0.56 & 0.13 & 0.23 & 0.080 & 0.037 & BDL & BDL \\
\hline & Daman & 187 & 1.9 & 0.12 & 0.34 & 2.6 & 0.46 & 2.0 & BDL & 0.67 & 1.8 & 9.9 & 0.14 & 0.021 & 0.22 & BDL & BDL & 0.025 & BDL \\
\hline & Richhe & 175 & 1.1 & 0.20 & 0.54 & 3.1 & 0.21 & 0.44 & 0.10 & 0.033 & 0.50 & 0.36 & 0.19 & BDL & 0.26 & 0.10 & 0.010 & BDL & BDL \\
\hline & Kyanjin Gumba & 175 & 0.89 & BDL & 0.15 & 5.2 & 0.09 & 0.46 & 0.31 & BDL & 1.2 & 0.35 & BDL & BDL & BDL & BDL & 0.0050 & BDL & 0.00073 \\
\hline & Yala Peak & 175 & 0.85 & BDL & 0.15 & 5.0 & 0.099 & 0.33 & 0.36 & 0.00 & 1.36 & 0.55 & BDL & BDL & BDL & 0.033 & 0.0089 & BDL & 0.00071 \\
\hline $\begin{array}{l}\text { 2012- } \\
\text { 2013 }\end{array}$ & Xixiabangma & 320 & 1.28 & 0.058 & 0.30 & 13 & 0.15 & 0.61 & 0.20 & 0.39 & 1.2 & 1.1 & 0.19 & 0.055 & 0.056 & 0.018 & BDL & 0.019 & 0.018 \\
\hline
\end{tabular}


Table S6. Calculated volumetric concentrations $\left(\mathrm{pg} / \mathrm{m}^{3}\right)$ of target compounds in air

\begin{tabular}{|c|c|c|c|c|c|c|c|c|c|c|c|c|c|c|c|c|c|c|}
\hline Seasons & Sampling sites & $\alpha-\mathrm{HCH}$ & $\beta-\mathrm{HCH}$ & $\gamma-\mathrm{HCH}$ & НСВ & $o, p^{\prime}-\mathrm{DDE}$ & $p, p^{\prime}-\mathrm{DDE}$ & $o, p^{\prime}-\mathrm{DDD}$ & $p, p^{\prime}-\mathrm{DDD}$ & $o, p^{\prime}$-DDT & $p, p^{\prime}-\mathrm{DDT}$ & РCB-28 & PCB-52 & PCB-101 & PCB-118 & РСB-153 & PCB-138 & PCB-180 \\
\hline \multirow[t]{7}{*}{ M12 } & Simara & 48.9 & 2.6 & 15.8 & 83.4 & 9.1 & 107.9 & 29.7 & 41.4 & 106.6 & 140.5 & BDL & 1.2 & 1.3 & 1.6 & 0.5 & 0.5 & BDL \\
\hline & Kathmandu & 6.3 & 0.3 & 3.7 & 8.9 & 0.5 & 3.2 & 0.9 & 1.1 & 4.7 & 7.1 & 1.4 & 0.6 & 0.5 & 0.2 & 0.2 & 0.1 & 0.1 \\
\hline & Syapru Besi & 17.6 & 0.8 & 8.7 & 24.8 & 0.4 & 5.3 & 0.5 & 0.9 & 6.4 & 10.8 & 1.2 & 0.5 & 0.7 & 0.9 & 0.2 & 0.2 & 0.2 \\
\hline & Daman & 6.9 & 0.3 & 0.9 & 9.3 & 1.1 & 4.2 & 1.2 & 1.9 & 7.5 & 9.7 & BDL & 0.2 & 0.2 & 0.2 & 0.1 & 0.1 & BDL \\
\hline & Richhe & 16.8 & 0.4 & 3.9 & 37.1 & BDL & 1.7 & 1.7 & 1.9 & 9.7 & 18.9 & 0.8 & 0.4 & 0.8 & 0.6 & 0.2 & 0.1 & 0.1 \\
\hline & Kyanjin Gumba & 3.6 & 0.1 & 0.6 & 9.1 & 0.01 & BDL & 0.3 & 0.2 & 2.2 & 1.5 & 0.1 & 0.1 & 0.1 & 0.04 & 0.02 & BDL & BDL \\
\hline & Yala Peak & 2.8 & BDL & 0.6 & 9.9 & BDL & BDL & 0.3 & BDL & 1.2 & 1.3 & BDL & 0.03 & 0.04 & 0.1 & 0.004 & BDL & BDL \\
\hline \multirow[t]{7}{*}{ N13 } & Simara & 22.5 & 1.9 & 22.1 & 114.4 & 3.5 & 23.4 & 5.4 & 16.7 & 35.6 & 53.2 & 2.5 & BDL & 0.4 & 0.6 & 0.2 & BDL & BDL \\
\hline & Kathmandu & 8.9 & 0.7 & 9.8 & 42.4 & 1.1 & 5.8 & 1.4 & 1.9 & 3.9 & 5.5 & 4.3 & 1.4 & 0.9 & 0.8 & 0.1 & 0.1 & BDL \\
\hline & Syapru Besi & 15.6 & 1.1 & 9.3 & 71.3 & 1.5 & 7.5 & 1.7 & 2.5 & 12.4 & 6.5 & 1.2 & 0.2 & 0.2 & 0.1 & BDL & BDL & BDL \\
\hline & Daman & 5.8 & 0.4 & 2.0 & 41.1 & 1.0 & 3.6 & 1.8 & 2.9 & 9.2 & 7.3 & 0.3 & BDL & BDL & BDL & 1.1 & BDL & BDL \\
\hline & Richhe & 20.2 & 1.5 & 6.7 & 148.9 & 0.2 & 0.1 & BDL & BDL & 2.5 & 1.4 & 3.6 & 0.4 & BDL & BDL & BDL & BDL & BDL \\
\hline & Kyanjin Gumba & 0.2 & 0.0 & 0.1 & 6.1 & 0.05 & 0.2 & 0.03 & BDL & 0.5 & 0.2 & 0.1 & BDL & BDL & 0.02 & BDL & BDL & BDL \\
\hline & Yala Peak & 0.2 & 0.02 & 0.1 & 7.4 & BDL & BDL & 0.02 & BDL & 0.2 & 0.1 & BDL & BDL & 0.02 & BDL & BDL & BDL & BDL \\
\hline \multirow[t]{7}{*}{ M13 } & Simara & 33.6 & 2.6 & 11.9 & 113.2 & 3.3 & 30.1 & 8.4 & 19.6 & 52.5 & 52.1 & 3.8 & 1.5 & 0.4 & BDL & 0.2 & 0.2 & BDL \\
\hline & Kathmandu & 4.3 & 0.2 & 2.8 & 13.8 & 0.6 & 2.3 & 1.0 & 1.3 & 5.1 & 3.2 & 1.3 & 0.6 & 0.2 & 0.03 & 0.1 & 0.1 & BDL \\
\hline & Syapru Besi & 4.8 & 1.5 & 0.5 & 7.7 & 0.3 & 0.9 & 0.2 & 0.5 & 2.4 & 2.9 & 0.3 & 0.1 & 0.1 & 0.06 & 0.1 & 0.2 & BDL \\
\hline & Daman & 15.6 & 0.2 & 7.8 & 48.6 & 1.4 & 7.3 & 1.7 & 2.4 & 18.3 & 13.5 & 0.8 & 0.4 & 0.5 & BDL & BDL & 0.2 & BDL \\
\hline & Richhe & 6.5 & BDL & 1.9 & 34.9 & 0.3 & 2.8 & 3.1 & 2.2 & 7.8 & 2.0 & 0.2 & 0.3 & 0.2 & BDL & BDL & BDL & BDL \\
\hline & Kyanjin Gumba & 0.5 & BDL & 0.2 & 6.4 & 0.0 & 0.5 & 0.3 & 0.2 & 1.2 & 0.3 & 0.03 & 0.04 & 0.05 & BDL & BDL & 0.01 & BDL \\
\hline & Yala Peak & 1.0 & BDL & 0.1 & 13.2 & 0.1 & 0.4 & 0.7 & 0.3 & 1.5 & 0.4 & BDL & 0.04 & 0.1 & BDL & BDL & BDL & BDL \\
\hline \multirow[t]{4}{*}{ N14 } & Simara & 43.1 & 1.5 & 36.1 & 405.5 & 10.8 & 64.7 & 12.1 & 29.1 & 75.8 & 49.9 & 9.2 & 3.5 & 2.8 & BDL & BDL & 0.3 & BDL \\
\hline & Kathmandu & 11.4 & 1.7 & 12.3 & 75.4 & 1.2 & 5.6 & 0.6 & 0.5 & 3.6 & 0.7 & 5.1 & 2.2 & 1.6 & BDL & BDL & 0.3 & BDL \\
\hline & Syapru Besi & 13.2 & 2.4 & 10.0 & 88.1 & 0.9 & 5.4 & 0.5 & 0.5 & 3.4 & BDL & 2.4 & 1.1 & 1.3 & BDL & BDL & BDL & BDL \\
\hline & Daman & 11.2 & 2.6 & 1.9 & 32.1 & 0.9 & 5.9 & BDL & 1.1 & 5.7 & 4.1 & 0.8 & 0.4 & 0.7 & BDL & BDL & 0.2 & BDL \\
\hline
\end{tabular}




\begin{tabular}{|c|c|c|c|c|c|c|c|c|c|c|c|c|c|c|c|c|c|c|}
\hline & Richhe & 7.7 & 0.7 & 1.3 & 77.9 & 0.7 & 3.8 & BDL & BDL & 3.1 & BDL & 3.7 & 0.8 & 0.7 & BDL & BDL & BDL & BDL \\
\hline & Kyanjin Gumba & 0.3 & BDL & 0.1 & 3.6 & 0.1 & 0.2 & 0.02 & 0.3 & 0.3 & 0.2 & BDL & BDL & BDL & BDL & 0.002 & BDL & BDL \\
\hline & Yala Peak & 0.1 & BDL & 0.1 & 3.7 & 0.1 & 0.1 & 0.0 & 0.2 & 0.3 & 0.1 & BDL & BDL & BDL & BDL & 0.004 & BDL & BDL \\
\hline \multirow[t]{8}{*}{ M14 } & Simara & 27.2 & 3.2 & 9.3 & 69.5 & 21.0 & 124.1 & 27.0 & 48.1 & 102.1 & 95.7 & 14.9 & BDL & 4.0 & 5.1 & 0.7 & BDL & 0.3 \\
\hline & Hetauda & 48.1 & 5.5 & 39.3 & 82.2 & 57.5 & 825.6 & 29.3 & 105.9 & 151.0 & 268.7 & 8.8 & 4.7 & 3.6 & 1.0 & 0.9 & BDL & 0.1 \\
\hline & Kathmandu & 3.8 & 0.2 & 4.2 & 12.0 & 1.2 & 3.7 & 2.0 & 0.6 & 2.2 & 3.3 & 1.6 & 0.2 & 0.9 & 0.2 & 0.1 & 0.1 & BDL \\
\hline & Syapru Besi & 14.4 & 2.6 & 8.7 & 43.5 & 1.5 & 7.5 & 3.0 & 1.9 & 8.4 & 4.6 & 3.4 & 0.8 & 1.4 & 0.5 & 0.2 & BDL & BDL \\
\hline & Daman & 3.4 & 0.2 & 0.6 & 4.7 & 0.8 & 3.5 & BDL & 1.2 & 3.3 & 17.7 & 0.2 & 0.0 & 0.4 & BDL & BDL & 0.04 & BDL \\
\hline & Richhe & 11.7 & 2.1 & 5.7 & 32.6 & 2.1 & 4.6 & 1.0 & 0.3 & 5.2 & 3.7 & 2.0 & BDL & 2.7 & 1.1 & 0.1 & BDL & BDL \\
\hline & Kyanjin Gumba & 1.0 & BDL & 0.2 & 5.8 & 0.1 & 0.5 & 0.3 & BDL & 1.3 & 0.4 & BDL & BDL & BDL & BDL & 0.006 & BDL & BDL \\
\hline & Yala Peak & 1.7 & BDL & 0.3 & 9.9 & 0.2 & 0.7 & 0.7 & BDL & 2.7 & 1.1 & BDL & BDL & BDL & 0.1 & 0.02 & BDL & BDL \\
\hline $\begin{array}{l}2012- \\
2013\end{array}$ & Xixiabangma & 0.9 & 0.04 & 0.2 & 9.5 & 0.1 & 0.4 & 0.1 & 0.3 & 0.8 & 0.8 & 0.1 & 0.04 & 0.04 & 0.01 & BDL & 0.01 & 0.01 \\
\hline
\end{tabular}




\section{Text S2. Air-mass trajectories from/to the sampling sites during seasons}

The forward and backward air-mass trajectories are calculated using the HYSPLIT (Hybrid Single-Particle Lagrangian Integrated Trajectory, Version 4.8) model ${ }^{6}$, developed by the Air Resource Laboratory (ARL) of the US National Oceanic and Atmospheric Administration (NOAA). The meteorological reanalysis data are obtained from the National Centers for Environmental Prediction's Global Data Assimilation System. For testing the source-receptor relationship between sites on the southern and northern slopes of the Himalayas, 36-hour trajectories both starting from the sampling sites on the southern slope and ending at the reference sites on the northern slope are calculated at heights of 100, 500, and $1000 \mathrm{~m}$ above ground level. The patterns obtained for different heights are similar, so we only discuss the patterns for $500 \mathrm{~m}$ in this manuscript. All trajectories are averaged for the entire period of passive air sampling.

The atmospheric circulation in South Asia shifts between seasons. In the monsoon season, wind blows from the Indian subcontinent to the Tibetan Plateau. About $40 \%$ airmasses move to the northeast and other air-masses hover near the sampling sites (Figure S2). Especially in the mid- and high-altitude regions, moving along the mountain slope (to the northeast) is one of the important paths of air masses (Figure S2c-f). In addition, 10\% air-masses move along the Trishuli/Gillon river valley from Syabru Besi (Figure S2c). In the non-monsoon season, westerly wind controls the Himalayas region, and fewer trajectories move from the sampling sites to the North $(<30 \%$ of the total trajectories, Figure S3), meaning that transport to the Himalayas may be weakened. To quantify the possibility of air-mass transport, we calculated the ratios $\left(r_{n}\right)$ of the number of air masses moving along our sampling transect to the total number of trajectories using the Equation 3 in the main text. This parameter is used in our model.

The backward trajectories ending at the sites on the northern slope of the Himalayas (Figure S4) match the situations of transport displayed by the forward trajectories in Figure S2-S3. Clearly, the transport paths need to be considered when simulating the atmospheric transport of pollutants over the Himalayas. 
(a) Simara

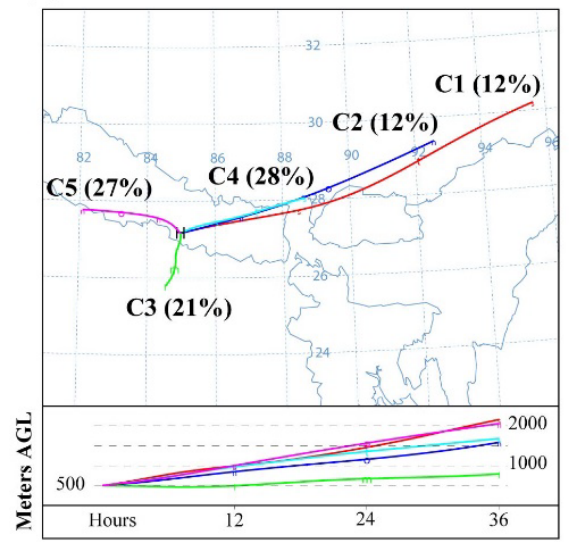

(c) Syabru Besi

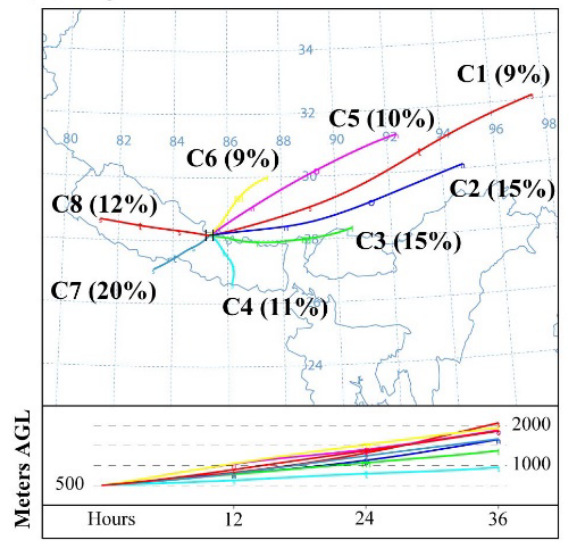

(e) Kyanjin Gumba

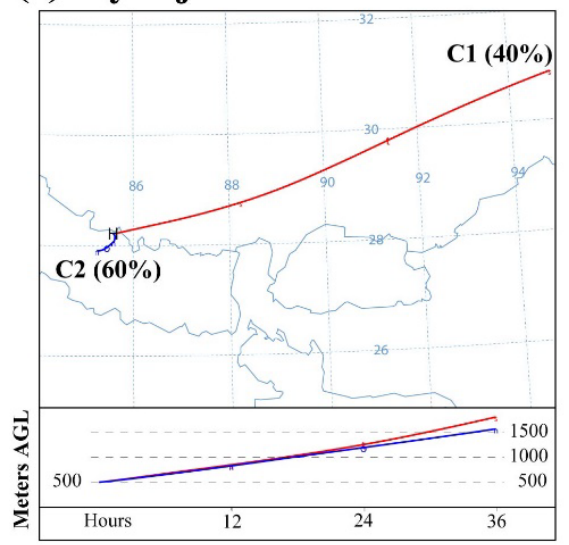

(b) Kathmandu

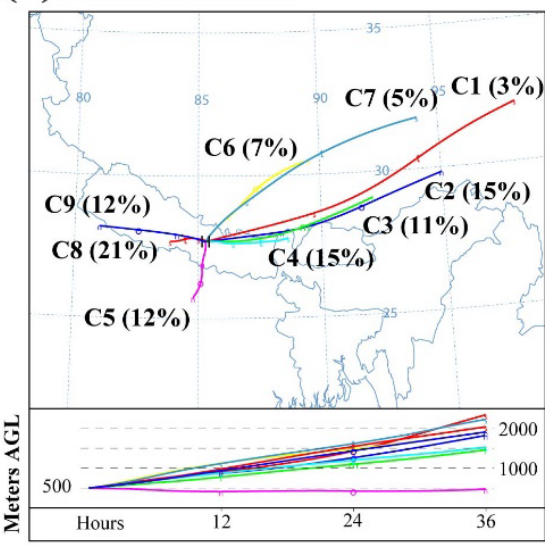

(d) Richhe

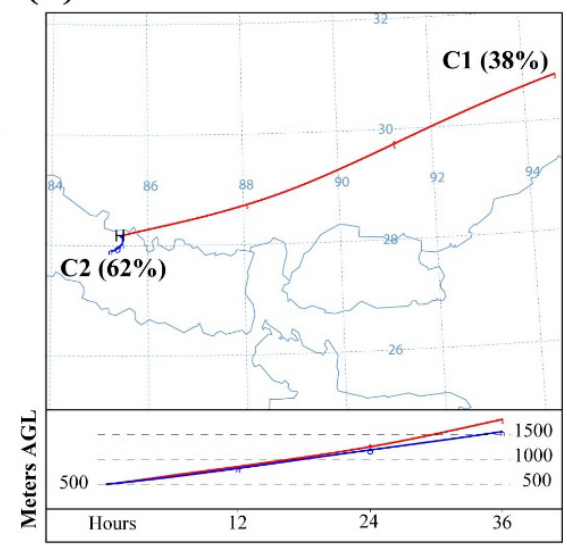

(f) Yala Peak

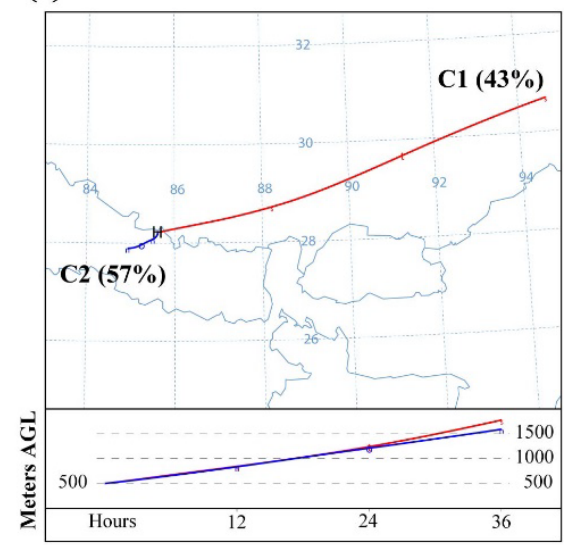

Figure S1. Forward trajectories of air masses from sampling sites to downwind regions during the monsoon season. The figures were created by NOAA HYSPLIT model (Version 4.8) ${ }^{6}$. 
(a) Simara

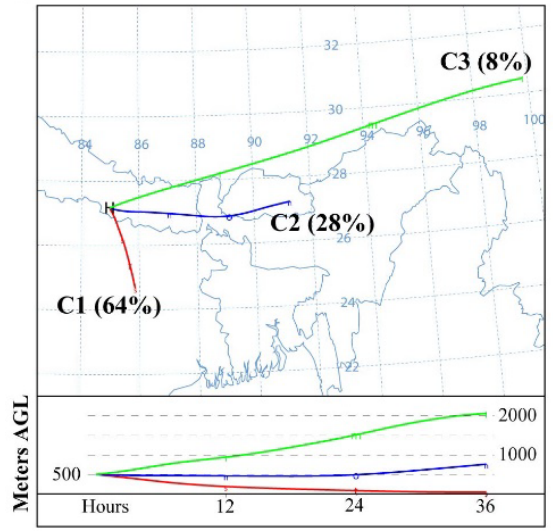

(c) Syabru Besi

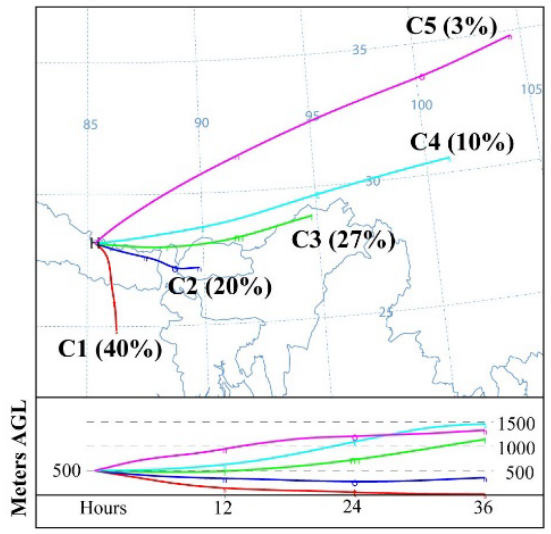

(e) Kyanjin Gumba

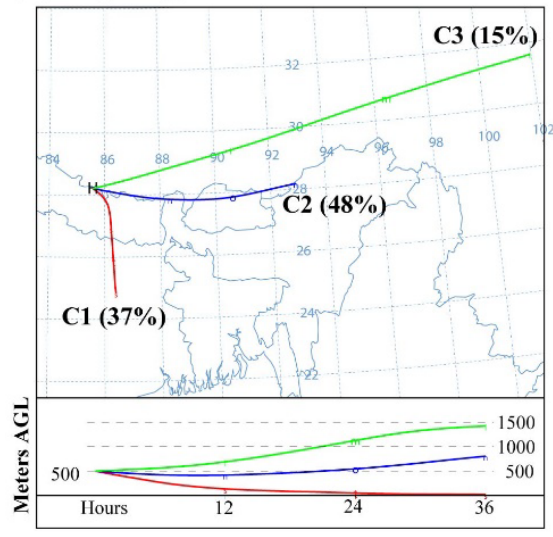

(b) Kathmandu

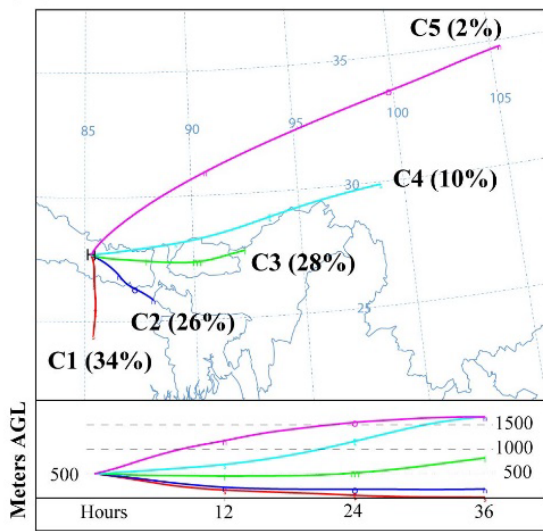

(d) Richhe

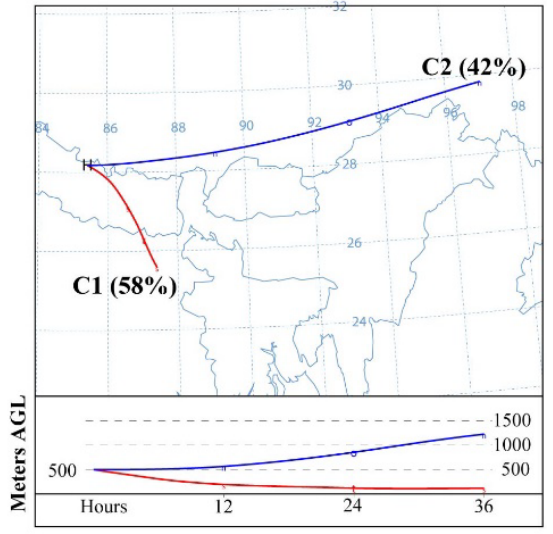

(f) Yala Peak

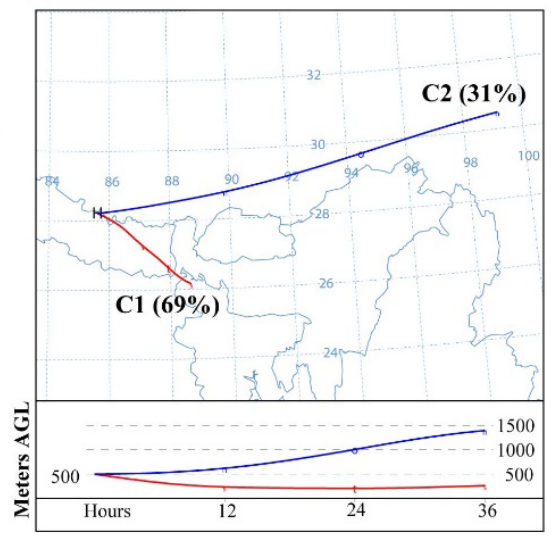

Figure S2. Forward trajectories of air masses from sampling sites to downwind regions during the non-monsoon season. The figures were created by NOAA HYSPLIT model (Version 4.8) ${ }^{6}$. 
(a) Gillon - monsoon

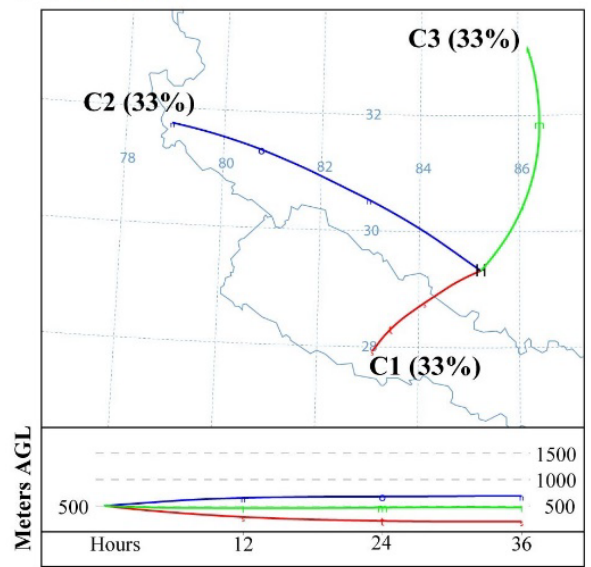

(c) Xixiabangma - monsoon

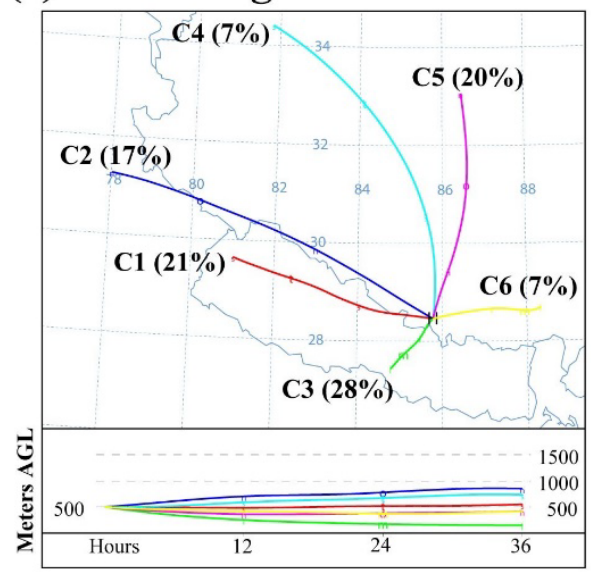

(b) Gillon - nonmonsoon

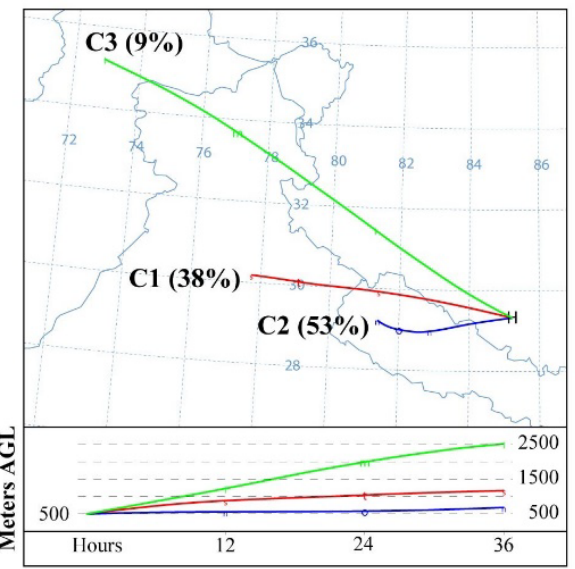

(d) Xixiabangma - nonmonsoon

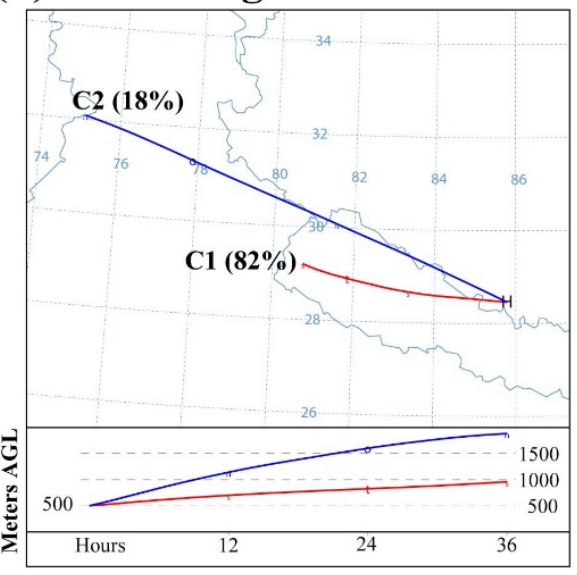

Figure S3. The backward trajectories of the receptor sites on the northern slope of the Himalayas. (a) and (b): Gillon; (c) and (d): Xixiabangma. The figures were created by NOAA HYSPLIT model (Version 4.8) ${ }^{6}$. 


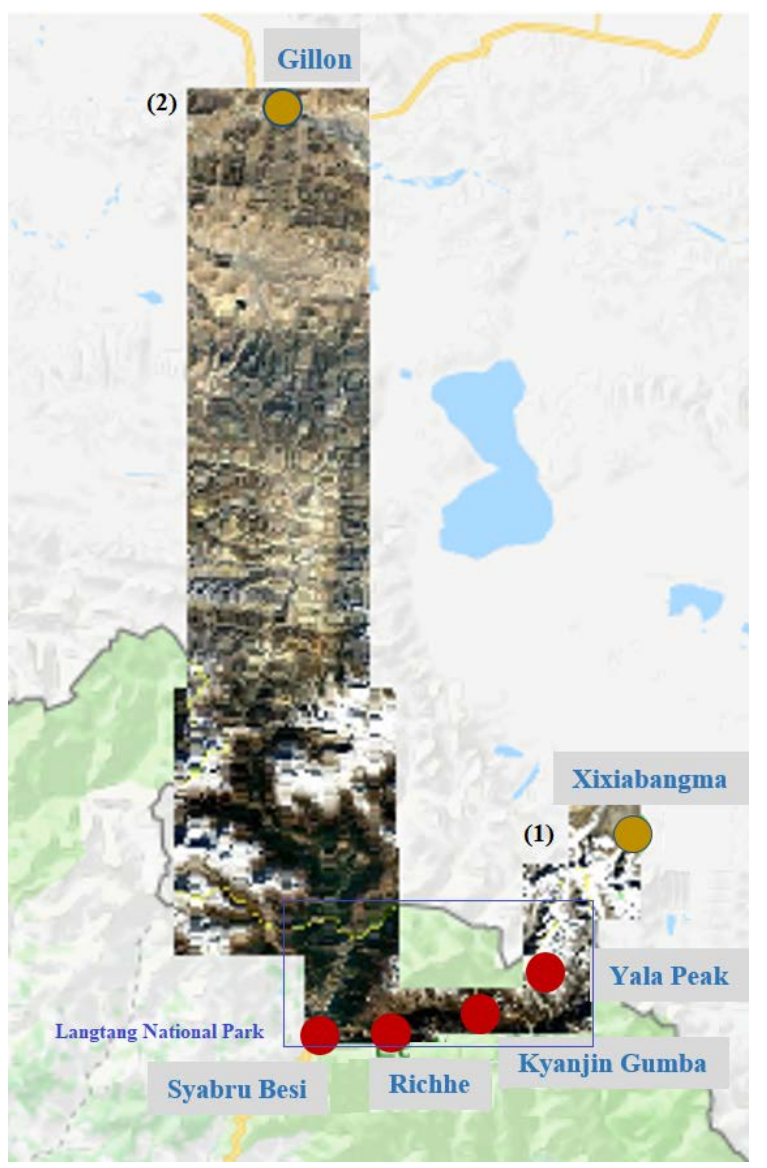

Figure S4. Transects and sampling sites simulated with the MCMPOP model (map data @2018 google). The satellite images (Image Landsat/Copernicus, Google Earth) show the regions (transects) simulated in this study: The modelling transect 1, mostly in the Langtang National Park (blue box), is co-located with the sampling transect over the Himalayas, whose altitudes range from $1350 \mathrm{~m}$ (Syabru Besi) to > $5000 \mathrm{~m}$ (Yala Peak and Xixiabangma). Modelling transect 2 is chosen to simulate the atmospheric transport along a low valley. 


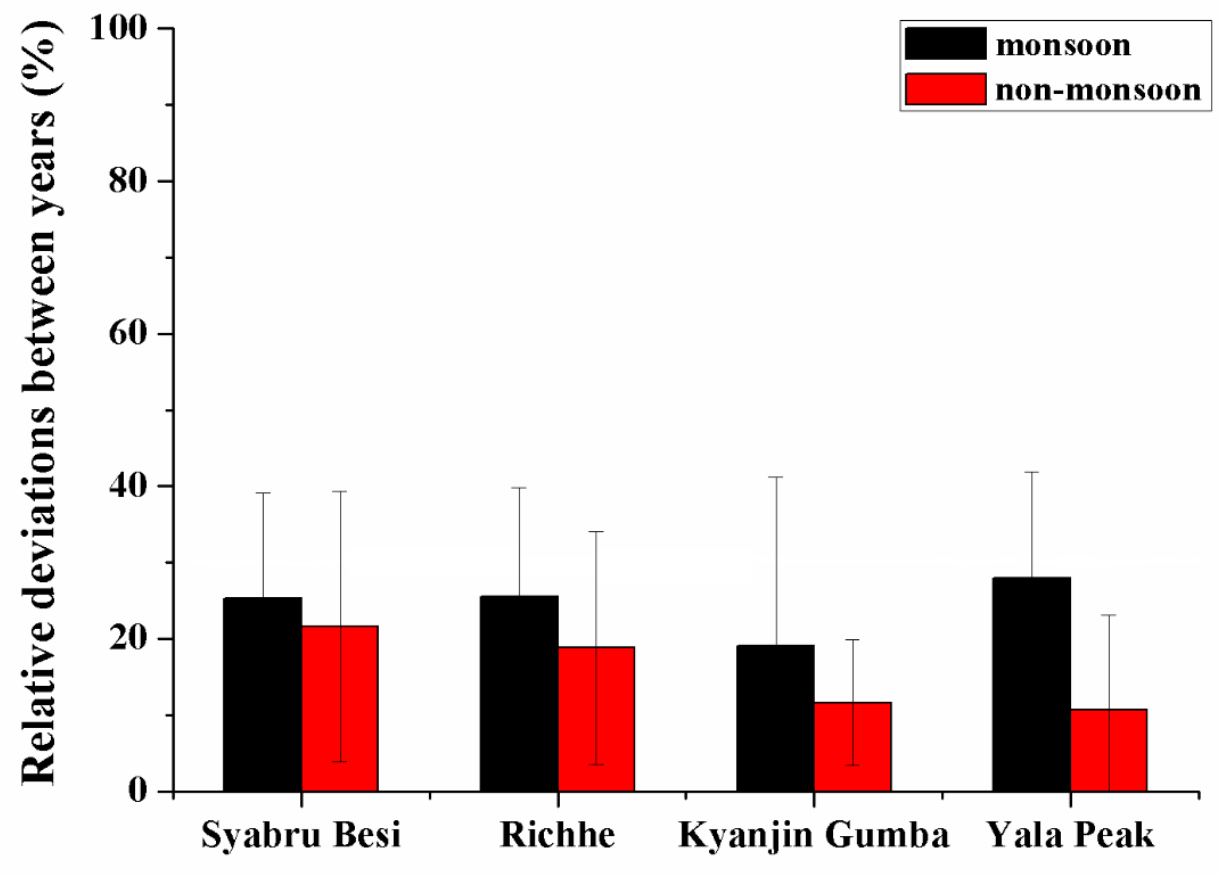

Figure S5. Relative deviations of the atmospheric POP concentrations between years to the average concentrations. The air samples were collected for consecutive 3 years, and the inter-annual variations of chemicals are between $10 \%$ and $30 \%$ for most chemicals. This error is just close to the normal analysis errors. The definition of steady state is that the concentration does not change with time ${ }^{7}$. We therefore assume that the pollutants achieved a quasi-steady state in this situation 


\section{Text S3. Description of the Multi-Compartment Mountain POP (MCMPOP) model}

\section{S3-1 Model input}

For simulating the 'real' surface conditions in the studying regions, products of remote sensing are used. The data on land use are derived from the MODIS product (MCD12Q1) with the IGBP classification in $0.05 \times 0.05$ degree. The 1 and 2 classes, 3-5 classes, 6 and 7 classes, 8-10 classes, and 12 and 14 classes in IGBP classification are merged as coniferous forest, deciduous forest, shrub, grassland, and agricultural field, respectively. The elevation data are from the ASTER digital elevation model (DEM) V002 product with a resolution of $30 \times 30$ meters. The data on leaf area index (LAI) are downloaded from Copernicus Global Land Service with a resolution of $0.0066 \times 0.0061$ degree. The resolution of each cell for this model is 1 kilometer $(\mathrm{km})$ along the transport direction, so the remote sensing data are averaged when re-gridding from their resolutions to $1 \times 1 \mathrm{~km}$.

The meteorological data in Simara and Kathmandu (low- and mid-altitude sites) are from the database of World Meteorological Organization (WMO), and the meteorological data at highaltitude sites (Kyanjin Gumba and Yala Peak) were measured by automatic weather station (AWS), which had been submitted to the Third Pole Environment Database (tpedatabase.cn) and Regional Database System of International Centre for Integrated Mountain Development (ICIMOD, rds.icimod.org), respectively. In addition, the meteorological data on the northern slope of the Himalayas were derived from Li et al. $(2011)^{5}$ and Wang et al. $(2010)^{8}$. The meteorological data during monsoon and non-monsoon seasons at the sampling sites are listed in Table S2. The meteorological parameters in other cells are calculated based on regressions between parameters at sites and altitude. A temperature of $0{ }^{\circ} \mathrm{C}$ is used as the threshold value between snow and rainfall. In addition, simulations revealed that the wind speed in the deep valley is only approximately $60 \%$ of the wind speed in the free atmosphere ${ }^{9}$, and thus wind speed is multiplied with a factor of 0.6 when simulating the transport in the Gillon valley.

The physicochemical properties of organic pollutants always vary with the changing ambient temperature. So the Henry's law constant $\left(K_{H}, \mathrm{~Pa} \mathrm{~m}{ }^{3} / \mathrm{mol}\right)$, octanol-air partition coefficient $\left(K_{o a}\right)$, and octanol-water partition coefficient $\left(K_{o w}\right)$ are calculated using relationships with temperature (Table S7). The interfacial sorption coefficient $\left[K_{i a}, \mathrm{~mol} /\left(\mathrm{m}^{2}\right.\right.$ surface $) / \mathrm{mol} /\left(\mathrm{m}^{3}\right.$ air $\left.)\right]$, which is used to estimate the interfacial sorption capacity of snow, is calculated based on poly-parameter linear free energy relationship (pp-LFER). The values of $K_{i a}$ are listed in Table S7. Other properties, 
namely molecular volume $\left(V_{m}\right)$ and half-lives $\left(\tau_{1 / 2}\right)$, are taken from related research papers (Table S7). All references for the physicochemical properties are listed in the footnotes of Table S7.

In Equation 2 in the main text, emission $(E)$ is one of the important input parameters. In this study, the observed concentrations of pollutants in Syabru Besi are used as the atmospheric input data in the first cell. The current rate of atmospheric contaminant deposition is not sufficient to explain levels in soil along the transect. This is because deposition in the past was higher and soils have accumulated a standing stock of POPs. To represent this in a steady-state model simulation of the present situation, we specify an annual emission rate to soil. For cells in which soil concentrations have been measured by Gong et al. (2014) ${ }^{10}$ and Wang et al. (2012) ${ }^{9}$, that emission rate is estimated by dividing the reported soil concentrations by 150 years. While the historical POP deposition period (1950 to the present time) is much shorter than 150 years, deposition in the period 1950 to 1990 was approx. 2 to 4 times higher than after $1990^{12}$, which we sought to take into account by virtually lengthening the period of accumulation. The emission in other cells derived by the interpolation of the regression between observed values and altitudes.

\section{S3-2 Main modules of model}

As described in the section entitled 'Model framework' in the main text, the two versions of the 2-D models with $1 \times 1 \mathrm{~km}$ resolution include 84 and 194 cells to represent the mountain slope and river valley from Syabru Besi, respectively. Two modules, called transfer module and transport module, are developed using mathematical software Matlab ${ }^{\circledR}$ R2014a (Version 8.3.0.532, MathWorks Inc.).

1) Transfer module

The transfer module is based on the fugacity concept. Three steps are involved when developing a Level III fugacity model ${ }^{7}$ :

First, fugacity capacities or Z-values $\left(\mathrm{mol} / \mathrm{m}^{3} / \mathrm{Pa}\right)$, which are parameters describing the equilibrium partitioning of a contaminant into different environmental phases, are calculated using temperature, partitioning coefficients, and the composition (i.e. volume fractions of gas phase, water, and organic matter) of different phases. The equations for calculating Zvalues in each medium are listed in Table S8.

Second, transfer rate coefficients or D-values $(\mathrm{mol} / \mathrm{Pa} / \mathrm{h})$, which are parameters for quantifying degradation and dynamic exchange processes between phases, are calculated using Z-values, mass transfer coefficients/rates, and area/volume of media. In this step, the model relies on areas of different land use in each cell as derived from satellite data. The equations for calculating D values are listed in Table S9. 
Finally, the mass balance equation for each medium, based on Equation 2 in the main text, are formulated (Equations S1 to S15):

\section{Atmosphere:}

$$
\begin{aligned}
& D_{a_{i n}} f_{a_{\text {in }}}+D_{a w} f_{w}+h D_{a s} A_{s} f_{s}+f r c_{\text {leaf }} D_{f a_{\text {dec }}} f_{f_{\text {dec }}}+D_{f a_{\text {con }}} f_{f_{\text {con }}}+f r c_{\text {leaf }} D_{f a_{s h}} f_{f_{s h}}+f r c_{\text {leaf }} D_{\text {fa }} a_{\text {grass }} f_{\text {grass }}+q_{s w} D_{f a_{f l}} f_{f_{f l}} \\
& +D_{s p-a} f_{s p}+h D_{a s} A_{d e c} f_{s_{d e c}}+h D_{a s} A_{c o n} f_{s_{c o n}}+h D_{a s} A_{s h} f_{s h}+h D_{a s} A_{\text {grass }} f_{\text {sgrass }}+h D_{a s} A_{f l} f_{f l} \\
& =f_{a}\left\{D_{a w}+h D_{a s}\left[A_{s}+\left(1-Q_{r f} * q_{s w}\right) A_{d e c}+\left(1-Q_{r f}\right) A_{c o n}+\left(1-Q_{r f}\right) A_{\text {grass }}+\left(1-Q_{r f}\right) A_{s h}\right.\right. \\
& \left.+\left(1-Q_{r f}\right) A_{f l}\right]+D_{a f_{c o n}}+f r c_{\text {leaf }} * D_{a f_{\text {dec }}}+\operatorname{frc}_{\text {leaf }} D_{a f_{s h}}+\operatorname{frc}_{\text {leaf }} D_{a f_{\text {grass }}}+q_{s w} D_{a f_{f l}}+D_{\text {ra }}+D_{p} \\
& +D_{p-w}+q_{s w} D_{p-f l}+h D_{p-f}\left(A_{\text {con }}+A_{\text {dec }}+A_{\text {grass }}+A_{s h}\right)+D_{p-s p}+D a_{\text {out }} \\
& \left.+\left[q_{r s}\left(h D_{m_{\text {rain }}}+h D_{d_{\text {rain }}}\right)+\left(1-q_{r s}\right) *\left(h D_{m_{\text {snow }}}+h D_{d_{\text {snow }}}\right)\right] *\left(A_{s}+A_{w}+A_{s p}\right)\right\}=f_{a} D_{T 1}
\end{aligned}
$$

Water:

$$
\begin{gathered}
f_{a}\left\{D_{a w}+D_{p-w}+\left[q_{r s}\left(h D_{m_{\text {rain }}}+h D_{d_{\text {rain }}}\right)+\left(1-q_{r s}\right)\left(h D_{m_{\text {snow }}}+h D_{d_{\text {snow }}}\right)\right] A_{w}\right\}+f_{s} D_{\text {lea }}+f_{\text {sed }} D_{d s}+f_{s p}\left(D_{\text {sp-w }}+D_{\text {spp-w }}\right) \\
=f_{w}\left(D_{\text {sus }}+D_{w-\text { sed }}+D_{r w}\right)=f_{w} D_{T 2}
\end{gathered}
$$

Bare soil:

$$
\begin{gathered}
E_{s}+f_{a}\left\{\left[h D_{a s}+q_{r s}\left(h D_{m_{\text {rain }}}+h D_{d_{\text {rain }}}\right)+\left(1-q_{r s}\right)\left(h D_{m_{\text {snow }}}+h D_{d_{\text {snow }}}\right)\right] A_{s}+D_{p}\right\}+f_{s p}\left(D_{s p-s}+D_{\text {spp-s }}\right) \\
=f_{s}\left(h D_{\text {lea }}+h D_{r s} Y_{s}+h D_{a s}\right) A_{s}=f_{s} D_{T 3}
\end{gathered}
$$

Deciduous forest:

$$
\begin{aligned}
& f_{a} D_{a f_{d e c}}=f_{f_{d e c}}\left[f r c_{l e a f} D_{f a_{d e c}}+\left(1-q_{s w}\right) D_{f b_{d e c}}+D_{r f_{d e c}}\right]=f_{f_{d e c}} D_{T 4} \\
& E_{S_{\text {dec }}}+f_{a}\left(1-Q_{r f} * q_{s w}\right)\left[h D_{a s}+q_{r s}\left(h D_{m_{\text {rain }}}+h D_{d_{\text {rain }}}\right)+\left(1-q_{r s}\right)\left(h D_{m_{\text {snow }}}+h D_{d_{\text {snow }}}\right)+h D_{p-f}\right] A_{\text {dec }} \\
& +\left(1-q_{\mathrm{sw}}\right) f_{f_{d e c}} D_{f b_{d e c}}=f_{s_{\text {dec }}}\left(h D_{\text {lea }}+h D_{r s} Y_{s}+h D_{a s}\right) A_{d e c}=f_{s_{d e c}} D_{T 11}
\end{aligned}
$$

Coniferous forest:

$$
f_{a} D_{a f_{c o n}}=f_{f_{c o n}}\left(D_{f a_{c o n}}+D_{f b_{c o n}}+D_{r f_{c o n}}\right)=f_{f_{c o n}} D_{T 5}
$$

$$
\begin{gathered}
E_{s_{c o n}}+f_{a}\left(1-Q_{r f}\right)\left[h D_{a s}+q_{r s}\left(h D_{m_{\text {rain }}}+h D_{d_{\text {rain }}}\right)+\left(1-q_{r s}\right)\left(h D_{m_{\text {snow }}}+h D_{d_{\text {snow }}}\right)+h D_{p-f}\right] A_{\text {con }}+f_{f_{\text {con }}} D_{f b_{\text {con }}} \\
=f_{s_{\text {con }}}\left(h D_{\text {lea }}+h D_{r s} Y_{s}+h D_{a s}\right) A_{\text {con }}=f_{s_{c o n}} D_{T 12}
\end{gathered}
$$

Shrub:

$$
\begin{gathered}
f_{a} D_{a f_{s h}}=f_{f_{s h}}\left[f r c_{\text {leaf }} D_{f a_{s h}}+\left(1-q_{s w}\right) D_{f b_{s h}}+D_{r f_{s h}}\right]=f_{f_{s h}} D_{T 6} \\
E_{s_{s h}}+f_{a}\left(1-Q_{r f}\right)\left[h D_{a s}+q_{r s}\left(h D_{m_{\text {rain }}}+h D_{d_{\text {rain }}}\right)+\left(1-q_{r s}\right)\left(h D_{m_{\text {snow }}}+h D_{d_{s n o w}}\right)+h D_{p-f}\right] A_{s h}+\left(1-q_{\mathrm{sw}}\right) f_{f_{s h}} D_{f b_{s h}} \\
=f_{s_{s h}}\left(h D_{\text {lea }}+h D_{r s} Y_{s}+h D_{a s}\right) A_{s h}=f_{s_{s h}} D_{T 13}
\end{gathered}
$$


Grassland:

$$
\begin{gathered}
f_{a} D_{\text {af } f_{\text {grass }}}=f_{f_{\text {grass }}}\left[\operatorname{fr} c_{\text {leaf }} D_{\text {fa }}\right. \text { grass } \\
\end{gathered}
$$

Agricultural field:

$$
\begin{gathered}
f_{a} D_{a f_{f l}}=f_{f_{f l}}\left(q_{s w} D_{f a_{f l}}+q_{s w} D_{r f_{f l}}\right)=f_{f_{f l}} D_{T 8} \\
E_{s_{f l}}+f_{a}\left(1-Q_{r f}\right)\left[h D_{a s}+q_{r s}\left(h D_{m_{\text {rain }}}+h D_{d_{\text {rain }}}\right)+h D_{p-f}\right] A_{f l}=f_{s_{f l}}\left(h D_{l e a}+h D_{r s} Y_{s_{f l}}+h D_{a s}\right) A_{f l}=f_{s_{f l}} D_{T 15}
\end{gathered}
$$

\section{Snowpack/ice:}

$$
f_{a}\left[\left(h D_{m_{\text {snow }}}+h D_{d_{s n o w}}\right) * A_{s p}+D_{s p-a}+D_{p-s p}\right]=f_{s p}\left(D_{s p-a}+D_{r s p}+D_{s p-s}+D_{s p-w}+D_{s p p-s}+D_{s p p-w}\right)=f_{s p} D_{T 9}
$$

\section{Sediments under water:}

$$
f_{w}\left(D_{\text {sus }}+D_{w-s e d}\right)=f_{\text {sed }} D_{\text {rse }}=f_{\text {sed }} D_{T 10}
$$

The definition, calculation, and value of the parameters in Equation S1-S15 are listed in Table S10. The main parameters and equations for forest, shrub, and farmland are taken from Wania and McLachlan (2001) ${ }^{13}$ and WECC report 1/2000 ${ }^{14}$; The main parameters and equations for wet deposition and snowpack/ice are based on Daly and Wania (2004) ${ }^{15}$ and Lei and Wania (2004) $)^{16}$. The other equations are compiled from Wania et al. (2006) ${ }^{17}$, Westgate and Wania (2013) $)^{18}$, and $\mathrm{Xu}$ et al. (2012) ${ }^{19}$. The fugacities $f$ in each phase are calculated by solving the linear system of equation (using all or some of the equations S1S15, depending on the land use present in a cell).

\section{2) Transport module}

We assume that the atmospheric boundary layer (ABL) in the studied regions is 1000 meters high and well mixed. Some air masses can be transported up to the top of the ABL (Figure S2-S4), so the air layer from 1000 to 3000 meters above the surface is also considered. We assumed that only $10 \%$ of pollutants can exchange between the ABL and this air layer during transport, but wet scavenging still occurs in the higher layer. In addition, because the 2-D model only simulates transport in one direction, we counted the number of total air-mass 
trajectories from each cell and the number of the trajectories into the following cell, and the fraction of trajectories that align with the transects is estimated as in Equation 3 in the main text. Finally, the output pollutants from one cell is multiplied with this fraction.

\section{S3-3 Calculation of concentrations, pool, and fluxes}

Concentrations $(C)$, stored amounts $(P o)$, and fluxes between phases 1 and $2\left(F_{12}\right)$ of contaminant are calculated from the fugacities $f$ as follows:

$$
C\left(\mathrm{pg} / \mathrm{m}^{3}\right)=f * Z * M W
$$

$* 10^{12}$

$$
\begin{aligned}
& P o\left(\mathrm{~g} / \mathrm{m}^{2}\right)=C * H * 10^{-12} \\
& F_{12}\left(\mathrm{~mol} / \mathrm{h} / \mathrm{m}^{2}\right)=\left(f_{1}-f_{2}\right) D
\end{aligned}
$$

Deposition fluxes $\left(F_{d e p}\right)$ with rain, snow, and particles are calculated based on the fugacity in air $\left(f_{a}\right)$ and the $\mathrm{D}$-values for deposition $\left(D_{d e p}\right)$ :

$$
=f_{a} * D_{d e p}
$$$$
F_{d e p}\left(m o l / h / m^{2}\right)
$$

Litterfall fluxes $\left(F_{l i t}\right)$ are calculated based on the fugacity in foliage $\left(f_{f}\right)$ and the D-values for litterfall $\left(D_{l i t}\right)$ :

$$
\begin{aligned}
& =f_{f} \\
& * D_{\text {lit }}
\end{aligned}
$$$$
F_{l i t}\left(\mathrm{~mol} / \mathrm{h} / \mathrm{m}^{2}\right)
$$

Atmospheric transport fluxes over the Himalayas $\left(F_{a t}, \mathrm{mg} / \mathrm{h} / \mathrm{km}^{2}\right)$ are calculated by the average output fluxes from the cells between the cell with highest elevation and \pm 10 cells. 
Table S7. Values and equations of physicochemical properties for compounds

\begin{tabular}{|c|c|c|c|c|c|c|c|c|c|c|}
\hline & \multirow{2}{*}{$\log K_{i a}$} & \multirow{2}{*}{$\log K_{H}$} & \multirow{2}{*}{$\log K_{o a}$} & \multirow{2}{*}{$\log K_{o w}$} & \multirow{2}{*}{$\mathrm{V}_{\mathrm{m}}{ }^{\mathrm{n}}$} & \multicolumn{5}{|c|}{ Half-lives of degradation in each media ${ }^{n}$} \\
\hline & & & & & & $\tau_{\mathrm{a} 1 / 2}$ & $\tau_{\mathrm{f} 1 / 2}$ & $\tau_{\mathrm{s} 1 / 2}$ & $\tau_{\text {sed1/2 }}$ & $\tau_{\mathrm{w} 1 / 2}$ \\
\hline Units & $\begin{array}{c}{\left[\mathrm{mol} /\left(\mathrm{m}^{2} \text { surface }\right)\right]} \\
/\left[\mathrm{mol} /\left(\mathrm{m}^{3} \text { air }\right)\right]\end{array}$ & $\mathrm{Pa} \mathrm{m}{ }^{3} / \mathrm{mol}$ & & & $\mathrm{cm}^{3} / \mathrm{mol}$ & Day & day & day & day & day \\
\hline$\alpha-\mathrm{HCH}$ & $-0.136^{a}$ & $-3171 / T+10.45^{c}$ & $3231 / T-3.23^{c}$ & $374.5 / T+2.55^{c}$ & 244 & 2000 & 1000 & 1687 & 55000 & 3364 \\
\hline$\beta-\mathrm{HCH}$ & $-0.126^{\mathrm{a}}$ & $-3454 / T+10.16^{c}$ & $4937 / T-7.69^{c}$ & $847.5 / T+1.07^{c}$ & 244 & 1500 & 1604 & 10000 & 55000 & 17000 \\
\hline$\gamma-\mathrm{HCH}$ & $-0.194^{\mathrm{a}}$ & $-2940 / T+9.29^{c}$ & $3415 / T-3.61^{c}$ & $282.2 / T+2.78^{c}$ & 244 & 3000 & 1000 & 17000 & 55000 & 17000 \\
\hline HCB & $-7.49^{a}$ & $-3013 / T+11.6^{d}$ & $2914 / T-2.39^{h}$ & $\log \left(H^{*} K_{o a} /(R T)\right)^{\mathrm{f}}$ & 161 & 7350 & 5000 & 55000 & 55000 & 55000 \\
\hline$p, p^{\prime}-\mathrm{DDT}$ & $-5.88^{a}$ & $-7453 / T+25.1^{e}$ & $3954 / T-3.2^{\mathrm{h}}$ & $\log \left(H^{*} K_{o a} /(R T)\right)^{\mathrm{f}}$ & 244 & 3000 & 2000 & 17000 & 55000 & 5500 \\
\hline$o, p^{\prime}-\mathrm{DDT}$ & $-5.88^{a}$ & $\log \left(K_{o w} R T\right)-\log K_{o a}{ }^{\mathrm{f}}$ & $4590 / T-5.95^{i}$ & $2693 / T+4.12^{\mathrm{j}, \mathrm{k}}$ & 244 & 4000 & 17520 & 3660 & 5500 & 5000 \\
\hline$p, p^{\prime}-\mathrm{DDE}$ & $-5.57^{\mathrm{a}}$ & $-7738 / T+27.8^{e}$ & $5116 / T-7.47^{\mathrm{h}}$ & $\log \left(H^{*} K_{o a} /(R T)\right)^{\mathrm{f}}$ & 227 & 2000 & 5000 & 55000 & 55000 & 55000 \\
\hline PCB-28 & $-2.35^{b}$ & $-2101 / \mathrm{T}+8.57^{\mathrm{g}}$ & $4102 / T-5.91 \mathrm{~g}$ & $22.33 / T+5.425^{1}$ & 205 & 550 & 1000 & 10000 & 17000 & 5500 \\
\hline PCB-52 & $-1.82^{b}$ & $-2189 / \mathrm{T}+8.79^{\mathrm{g}}$ & $4251 / T-6.04^{\mathrm{g}}$ & $54.52 / T+5.842^{1}$ & 220 & 1700 & 1700 & 17000 & 55000 & 10000 \\
\hline PCB-101 & $-1.54^{\mathrm{b}}$ & $-3233 / \mathrm{T}+12.21^{\mathrm{g}}$ & $4291 / T-5.50^{\mathrm{g}}$ & $36.4 / T+6.282^{1}$ & 235 & 1700 & 10000 & 100000 & 55000 & 31000 \\
\hline
\end{tabular}

${ }^{a}$ Abraham et al.(2002) ${ }^{20}$; bei and Wania (2004) ${ }^{16}$; ${ }^{\mathrm{b}}$ Xiao et al.(2004) ${ }^{21}$; ${ }^{\mathrm{d}}$ Jantunen and Bidleman (2006) ${ }^{22}$; ${ }^{\mathrm{e}}$ Cetin et al.(2006) $)^{23}$; ${ }^{\mathrm{f}}$ Meylan and Howard (2005) ${ }^{24}$; ${ }^{\mathrm{g}} \mathrm{Li}$ et al.(2003) ${ }^{25}$; ${ }^{\mathrm{h}}$ Shen and Wania $(2005)^{26}$; ${ }^{\mathrm{i}}$ Shoeib and Harner $(2002)^{27}$; ${ }^{\mathrm{j}}$ Li et al.(2015) ${ }^{28}$; ${ }^{\mathrm{k}}$ Beyer et al.(2002) ${ }^{29}$; ${ }^{1}$ Paasivirta and Sinkkonen $(2009)^{30}$; ${ }^{\mathrm{n}}$ compiled by the data of Aronson et al.(1998) ${ }^{31}$ and Wania and Daly (2002) $)^{32}$ 
Table S8. Equation for Z-values ( $\left.\mathrm{mol} / \mathrm{m}^{3} / \mathrm{Pa}\right)$ and related parameters

\begin{tabular}{|c|c|c|c|c|c|}
\hline Phases & Equations & Parameters & Units & Values & Reference \\
\hline \multicolumn{6}{|l|}{ Atmosphere } \\
\hline \multirow[t]{2}{*}{ Gas } & $\mathrm{Z}_{\mathrm{a}}=1 / \mathrm{RT}$ & R: ideal gas constant & $\mathrm{J} / \mathrm{K} / \mathrm{mol}$ & 8.314 & \\
\hline & & $\mathrm{T}$ : Temperature & $\mathrm{K}$ & & \\
\hline Aerosol & $\mathrm{Z}_{\mathrm{p}}=\mathrm{K}_{\mathrm{p}} \mathrm{Z}_{\mathrm{a}}$ & $\mathrm{K}_{\mathrm{p}}^{\prime}$ : gas-particle partition coefficient & & & \\
\hline \multicolumn{6}{|c|}{ 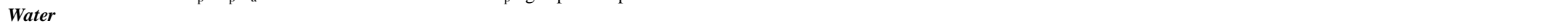 } \\
\hline Pure water & $\mathrm{Z}_{\mathrm{w}}=1 / \mathrm{K}_{\mathrm{H}}$ & $\mathrm{K}_{\mathrm{H}}$ : Henry's law constant & $\mathrm{Pa} \mathrm{m}^{3} / \mathrm{mol}$ & & \\
\hline Suspension & $\mathrm{Z}_{\mathrm{sus}}=\mathrm{Z}_{\mathrm{w}} \mathrm{K}_{\text {sus }}$ & $\mathrm{K}_{\text {sus }}$ : Suspension matter/water partition coefficient & & & \\
\hline \multicolumn{6}{|c|}{ 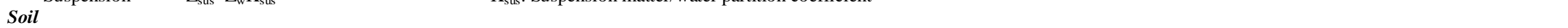 } \\
\hline Organic matter & $\mathrm{Z}_{\mathrm{som}}=\mathrm{Z}_{\mathrm{a}} \mathrm{K}_{\mathrm{oa}}$ & $\mathrm{K}_{\mathrm{oa}}$ : octanol-air partition coefficient & & & \\
\hline Mineral matter & $\mathrm{Z}_{\mathrm{mm}}=\mathrm{K}_{\mathrm{mmw}} \mathrm{Z}_{\mathrm{w}}$ & $\mathrm{K}_{\mathrm{mm} w}$ : Mineral matter/water partition coefficient & & & \\
\hline \multirow[t]{4}{*}{ Bulk soil } & $Z_{\mathrm{s}}=\varphi_{\mathrm{sa}} Z_{\mathrm{a}}+\varphi_{\mathrm{sw}} Z_{\mathrm{w}}+\varphi_{\mathrm{som}} Z_{\mathrm{som}}+\varphi_{\mathrm{smm}} Z_{\mathrm{mm}}$ & $\varphi_{\text {sa: }}$ volume fraction of air in soil & $\%$ & & \\
\hline & & $\varphi_{\mathrm{sw}}:$ volume fraction of water in soil & $\%$ & & \\
\hline & & $\varphi_{\text {som }}$ : volume fraction of organic matter in soil & $\%$ & & \\
\hline & & $\varphi_{\mathrm{smm}}:$ volume fraction of mineral matter in soil & $\%$ & & \\
\hline \multicolumn{6}{|c|}{ Psmin. } \\
\hline Sediment & $Z_{\mathrm{se}}=\mathrm{Z}_{\mathrm{w}} \mathrm{K}_{\mathrm{se}}$ & $\mathrm{K}_{\mathrm{se}}$ : Sediment/water partition coefficient & & & \\
\hline Bulk sediment & $Z_{\text {bse }}=\varphi_{\text {se-w }} Z_{w}+\left(1-\varphi_{\text {se-w }}\right) Z_{\text {se }}$ & $\varphi_{\text {se-w: }}$ volume fraction of water in sediment & & & \\
\hline \multicolumn{6}{|c|}{ ser } \\
\hline Foliage & $\begin{array}{l}Z_{\mathrm{f}}=K_{\mathrm{fa}} Z_{\mathrm{a}} \\
\mathrm{Z}_{\mathrm{f}} \text { con }: Z \text { value of coniferous canopy } \\
\mathrm{Z}_{\mathrm{f} \text { dec }}: \mathrm{Z} \text { value of deciduous canopy }\end{array}$ & $\mathrm{K}_{\mathrm{fa}}$ : foliage-air partition coefficient, & & $\mathrm{K}_{\mathrm{fa}}=\mathrm{M}^{*} \mathrm{~K}_{\mathrm{oa}}{ }^{\mathrm{N}}$ & [13] \\
\hline \multicolumn{6}{|c|}{ 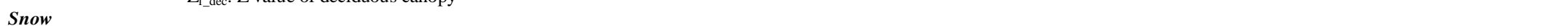 } \\
\hline Interface & $\mathrm{Z}_{\mathrm{i}}=\mathrm{K}_{\mathrm{i}} \mathrm{Z}_{\mathrm{a}}$ & $\mathrm{K}_{\mathrm{ia}}$ : interfacial sorption coefficient & $\begin{array}{c}\mathrm{mol} /\left(\mathrm{m}^{2} \text { surface }\right) \\
/ \mathrm{mol} /\left(\mathrm{m}^{3} \text { air }\right)\end{array}$ & $\begin{array}{c}\log K_{\mathrm{ia}}=3.60 \sum \alpha_{2}{ }^{\mathrm{H}}+5.11 \sum \beta_{2}{ }^{\mathrm{H}}+0.635 \log \mathrm{L}^{16}-8.47 \\
\sum \alpha_{2}{ }^{\mathrm{H}} \text { : summation hydrogen bond acidity } \\
\sum \beta_{2}{ }^{\mathrm{H}} \text { : summation hydrogen bon basicity } \\
\mathrm{L}^{16} \text { : gas-hexadecane partition coefficient }\end{array}$ & [33] \\
\hline \multirow[t]{2}{*}{ Organic matter } & $\mathrm{Z}_{\mathrm{om}}=\mathrm{K}_{\mathrm{oa}}\left(\mathrm{TSP} / \rho_{\mathrm{oct}}\right) \mathrm{Z}_{\mathrm{a}}$ & TSP: density of atmospheric particles & $\mathrm{g} / \mathrm{m}^{3}$ & & \\
\hline & & $\rho_{\text {oct }}$ : density of octanol & $\mathrm{g} / \mathrm{m}^{3}$ & & \\
\hline \multirow[t]{3}{*}{ Snowpack } & $\begin{array}{l}Z_{\text {sp }}=Z_{\mathrm{a}} \varphi_{\text {sp } \_}+Z_{w} \varphi_{\text {sp } \_}+Z_{\mathrm{i}} \mathrm{S} A_{\text {snow }} \rho_{\text {snow }} \\
+Z_{\text {om }} \varphi_{\text {sp_o }}\end{array}$ & $\begin{array}{l}\varphi_{\text {sp_a: }}: \text { volume fraction of air in snowpack } \\
\varphi_{\text {sp_w }}: \text { volume fraction of water in snowpack } \\
\varphi_{\text {sp_o }}: \text { volume fraction of organic matter in snowpack }\end{array}$ & & & \\
\hline & & $\mathrm{SA}_{\text {snow }}:$ specific snow surface area & $\mathrm{m}^{2} / \mathrm{g}$ & & \\
\hline & & $\rho_{\text {snow }}:$ density of snow & $\mathrm{g} / \mathrm{m}^{3}$ & & \\
\hline \multicolumn{6}{|l|}{ Precipitation } \\
\hline \multirow[t]{3}{*}{ Falling snow } & $Z_{\text {snow }}=Z_{i} A_{\text {snow }} \rho_{\mathrm{mw}}+Q_{s} \varphi_{\mathrm{p}} Z_{0} m f_{p_{\_} \mathrm{o}}$ & $\varphi_{\mathrm{p}}:$ volume fraction of aerosols in air & $\mathrm{m}^{3} / \mathrm{m}^{3}$ & & \\
\hline & & $\mathrm{Q}_{\mathrm{s}}$ : particle scavenging ratio for snow & & & \\
\hline & & $\begin{array}{l}\mathrm{mf}_{\mathrm{p}_{\mathrm{o}}}: \text { mass fraction of organic matter in atmospheric } \\
\text { particles }\end{array}$ & & & \\
\hline Rain & $Z_{\text {rain }}=Z_{w}+Q_{r} \varphi_{p} Z_{p}$ & $\mathrm{Q}_{\mathrm{r}}$ : particle scavenging ratio for rain & & & \\
\hline
\end{tabular}


Table S9. Equation of D-values (mol/Pa/h) and related parameters

\begin{tabular}{|c|c|c|c|c|c|}
\hline Phase and Processes & Equation & Parameter & $\begin{array}{l}\text { Units of } \\
\text { parameters }\end{array}$ & Value & Reference \\
\hline \multicolumn{6}{|l|}{ Air } \\
\hline \multirow[t]{2}{*}{ Gas exchange with water } & $D_{a w}=1 /\left[1 /\left(k_{v a} A_{w} Z_{a}\right)+1 /\left(k_{v w} A_{w} Z_{w}\right)\right]$ & $\begin{array}{l}\mathrm{k}_{\mathrm{va}} \text { : mass transfer coefficient for the stagnant } \\
\text { atmospheric boundary layer over water }\end{array}$ & $\mathrm{m} / \mathrm{h}$ & 3 & [7] \\
\hline & & $\begin{array}{l}k_{\mathrm{vw}} \text { : mass transfer coefficient for the stagnant water } \\
\text { layer at the air-water interface }\end{array}$ & $\mathrm{m} / \mathrm{h}$ & 0.03 & {$[7]$} \\
\hline \multirow[t]{4}{*}{ Gas exchange with soil } & $\begin{array}{l}\mathrm{hD}_{\mathrm{as}}=1 /\left(1 /\left(\mathrm{k}_{\mathrm{as}} \mathrm{Z}_{\mathrm{a}}\right)+1 /\left(\mathrm{k}_{\mathrm{a} \_ \text {pore }} \mathrm{Z}_{\mathrm{a}}+\mathrm{k}_{\mathrm{w} \_ \text {pore }}\right.\right. \\
\left.\mathrm{Z}_{\mathrm{w}}+\mathrm{k}_{\text {solid }} \varphi_{\text {som }} \mathrm{Z}_{\text {som }}\right)\end{array}$ & $\begin{array}{l}\mathrm{k}_{\mathrm{as}} \text { : mass transfer coefficient for the atmospheric } \\
\text { boundary layer above the air-soil interface }\end{array}$ & $\mathrm{m} / \mathrm{h}$ & 1 & {$[7]$} \\
\hline & & $\begin{array}{l}k_{\text {a_pore: }} \text { mass transfer coefficient for diffusion in the } \\
\text { air pore space }\end{array}$ & $\mathrm{m} / \mathrm{h}$ & $\begin{array}{l}\mathrm{k}_{\mathrm{a} \_ \text {pore }}=\mathrm{B}_{\mathrm{ma}} / \mathrm{Y}_{\mathrm{s}} \\
\mathrm{B}_{\mathrm{ma}} \text { : molecular diffusion coefficient } \\
\text { in air, } 0.04 \mathrm{~m}^{2} / \mathrm{h} \\
\mathrm{Y}_{\mathrm{s}} \text { : diffusion length in soil, } 0.05 \mathrm{~m}\end{array}$ & {$[7]$} \\
\hline & & $\begin{array}{l}k_{w_{\text {}} \text { pore }} \text { : mass transfer coefficient for diffusion in the } \\
\text { water pore space }\end{array}$ & $\mathrm{m} / \mathrm{h}$ & $\begin{array}{l}\mathrm{k}_{\mathrm{a}} \text { pore }=\mathrm{B}_{\mathrm{mw}} / \mathrm{Y}_{\mathrm{s}} \\
\mathrm{B}_{\mathrm{mw}} \text { : molecular diffusion coefficient } \\
\text { in water, } 4.0^{*} 10^{-6} \mathrm{~m}^{2} / \mathrm{h}\end{array}$ & [7] \\
\hline & & $\begin{array}{l}\mathrm{k}_{\text {solid: }} \text { mass transfer coefficient for solid phase } \\
\text { diffusion in soils }\end{array}$ & $\mathrm{m} / \mathrm{h}$ & & \\
\hline \multirow{2}{*}{$\begin{array}{l}\text { Gas exchange with foliage } \\
\text { Chemical evaporation from foliage }\end{array}$} & $\mathrm{D}_{\mathrm{fa}}=\mathrm{LAI} * \mathrm{~A}_{\mathrm{f}} \mathrm{U}_{\mathrm{d}-\mathrm{g}} \mathrm{Z}_{\mathrm{a}}$ & $\mathrm{A}_{\mathrm{f}}:$ foliage ground area & $\mathrm{m}^{2}$ & & \\
\hline & & $\mathrm{U}_{\mathrm{d}-\mathrm{g}}$ : gaseous deposition velocity to foliage & $\mathrm{m} / \mathrm{h}$ & $\begin{array}{l}129.6 \text { (deciduous) } \\
42.1 \text { (coniferous) }\end{array}$ & [13] \\
\hline Dry particle deposition above bare soil & $\mathrm{D}_{\mathrm{p}}=\mathrm{A}_{\mathrm{s}} \mathrm{U}_{\mathrm{p}} \mathrm{Z}_{\mathrm{p}}$ & $\mathrm{A}_{\mathrm{a}}$ : air ground area & $\mathrm{m}^{2}$ & - & [7] \\
\hline Dry particle deposition above water & $\mathrm{D}_{\mathrm{P} \_\mathrm{w}}=\mathrm{A}_{\mathrm{w}} \mathrm{U}_{\mathrm{p} \_\mathrm{w}} \mathrm{Z}_{\mathrm{p}}$ & & & 10.8 & {$[/]$} \\
\hline $\begin{array}{l}\text { Dry particle deposition under forest } \\
\text { foliage }\end{array}$ & $D_{p_{-}}=\left(A_{\text {con }}+A_{d e c}+A_{s h}+A_{g r a s s}\right) U_{p \_-1} Z_{p}$ & & & & \\
\hline $\begin{array}{l}\text { Dry particle deposition under } \\
\text { agricultural plants }\end{array}$ & $\mathrm{D}_{\mathrm{P}_{-} \mathrm{fl}}=\mathrm{A}_{\mathrm{fl}} \mathrm{U}_{\mathrm{P} \_\mathrm{fl}} \mathrm{Z}_{\mathrm{p}}$ & & & & \\
\hline \multirow{4}{*}{$\begin{array}{l}\text { Wet particle deposition for rain } \\
\text { Wet particle deposition for snow } \\
\text { Wet deposition dissolution } \\
\text { Absorption of gas by snow during } \\
\text { falling }\end{array}$} & $\mathrm{hD}_{\mathrm{d}_{-} \text {rain }}=\mathrm{U}_{\mathrm{pre}} \mathrm{Q}_{\mathrm{r}} \mathrm{Z}_{\mathrm{p}}$ & $\mathrm{U}_{\text {pre: }}$ precipitation rate & $\mathrm{m} / \mathrm{h}$ & & \\
\hline & $\mathrm{hD}_{\mathrm{d}_{\mathrm{d} \text { snow }}}^{-}=\mathrm{U}_{\mathrm{pre}} \mathrm{Q}_{\mathrm{s}} \mathrm{Z}_{\mathrm{p}}$ & & & & \\
\hline & $\mathrm{hD}_{\mathrm{m} \_ \text {rain }}=\mathrm{Z}_{\mathrm{w}} \mathrm{U}_{\text {pre }}$ & & & & \\
\hline & $\mathrm{hD}_{\mathrm{m} \_ \text {snow }}=\mathrm{U}_{\text {pre }} \mathrm{Z}_{\mathrm{i}} \mathrm{SA}_{\text {snow }} \rho_{\mathrm{mw}}$ & & & & \\
\hline Degradation in air & $\mathrm{D}_{\mathrm{ra}}=\mathrm{K}_{\mathrm{ra}} \mathrm{V}_{\mathrm{a}} \mathrm{Z}_{\mathrm{a}}$ & $\begin{array}{l}\mathrm{K}_{\mathrm{ra}} \text { : Reaction rate in air } \\
\mathrm{V}_{\mathrm{a}} \text { : volume of air compartment }\end{array}$ & $\begin{array}{l}\mathrm{h}^{-1} \\
\mathrm{~m}^{3}\end{array}$ & & \\
\hline \multirow{2}{*}{$\begin{array}{l}\text { Advection into region } \\
\text { Advection out of region }\end{array}$} & $\mathrm{D}_{\mathrm{a}-\mathrm{in}}=\left(\mathrm{Z}_{\mathrm{a}-1}+\varphi_{\mathrm{p}-1} \mathrm{Z}_{\mathrm{p}-1}\right) \mathrm{G}_{\mathrm{a}}$ & $\mathrm{G}_{\mathrm{a}}$ : air advection rate & $\mathrm{m}^{3} / \mathrm{h}$ & & \\
\hline & $D_{a_{-} \text {out }}=\left(Z_{\mathrm{a}}+\varphi_{\mathrm{p}} Z_{\mathrm{p}}\right) \mathrm{G}_{\mathrm{a}}$ & & & & \\
\hline \multicolumn{6}{|l|}{ Water } \\
\hline Sedimentation of suspension in water & $\mathrm{D}_{\text {sus }}=\mathrm{A}_{\mathrm{w}} \mathrm{K}_{\mathrm{dw}} \mathrm{Z}_{\text {sus }}$ & $\begin{array}{l}K_{d w} \text { : rate of sedimentation } \\
A_{w} \text { : water ground area }\end{array}$ & $\begin{array}{l}\mathrm{m} / \mathrm{a} \\
\mathrm{m}^{2}\end{array}$ & 0.0004 & [7] \\
\hline Resuspension of sediment & $\mathrm{D}_{\mathrm{ds}}=\mathrm{A}_{\mathrm{w}} \mathrm{K}_{\mathrm{se}} \mathrm{Z}_{\mathrm{se}}$ & $\mathrm{K}_{\mathrm{se}}$ : rate of resuspension & $\mathrm{m} / \mathrm{a}$ & 0.0001 & [7] \\
\hline \multirow[t]{2}{*}{$\begin{array}{l}\text { Exchange diffusion between water and } \\
\text { sediment }\end{array}$} & $\begin{array}{l}D_{w_{-} s e d}=A_{w} /\left(1 /\left(k_{s w} Z_{w}\right)+Y_{\text {sed }} /\left(B_{m w}\right.\right. \\
\left.\left.Z_{w}\right)\right)\end{array}$ & $\begin{array}{l}\mathrm{k}_{\mathrm{sw}} \text { : MTC for diffusion across benthic boundary } \\
\text { layer }\end{array}$ & $\mathrm{m} / \mathrm{h}$ & 0.01 & [7] \\
\hline & & $\mathrm{Y}_{\text {sed }}:$ diffusion length in sediment & $\mathrm{m}$ & 0.005 & [7] \\
\hline Degradation in water & $\mathrm{D}_{\mathrm{rw}}=\mathrm{K}_{\mathrm{rw}} \mathrm{V}_{\mathrm{w}} \mathrm{Z}_{\mathrm{w}}$ & $\mathrm{K}_{\mathrm{rw}}$ : Reaction rate in bulk water & $h^{-1}$ & & \\
\hline
\end{tabular}




\section{Sedimen}

Degradation in sediment

Soil

Leaching in soil

Degradation in soil

Total deposition from air to bare soil

Foliage

Chemical evaporation from foliage

Foliar uptake of chemical from air

Litterfall of coniferous foliage to soils

Litterfall of deciduous foliage to soils

Degradation in foliage

\section{Snowpack}

Reaction in snowpack

Snow to air transfer

Meltwater runoff to soil

Meltwater runoff to fresh water

Particle flush to soil

Particle flush to fresh water
$\mathrm{D}_{\mathrm{rs}}=\mathrm{K}_{\mathrm{rs}} \mathrm{V}_{\mathrm{s}} \mathrm{Z}_{\mathrm{s}}$

$\mathrm{D}_{\mathrm{t} \_\mathrm{s}}=\mathrm{D}_{\mathrm{ax}}+\mathrm{q}_{\mathrm{rs}}\left(\mathrm{D}_{\mathrm{m} \_ \text {rain }}+\mathrm{D}_{\mathrm{d} \_ \text {rain }}\right)+\left(1-\mathrm{q}_{\mathrm{rs}}\right)$

$\left(\mathrm{D}_{\mathrm{m} \_ \text {snow }}+\mathrm{D}_{\mathrm{d} \_ \text {snow }}\right)$

$\mathrm{D}_{\mathrm{fa}}=\mathrm{LAI} * \mathrm{~A}_{\mathrm{f}} \mathrm{U}_{\mathrm{d}-\mathrm{g}} \mathrm{Z}$

$D_{\text {af }}=D_{\text {fa }}+D_{\mathrm{p}}+q D_{\text {rain }}+(1-q) D_{\text {snow }}=A_{f}$ $\left[\left(\mathrm{LAI} * \mathrm{U}_{\mathrm{d}-\mathrm{g}} \mathrm{Z}_{\mathrm{a}}+\mathrm{U}_{\mathrm{d}-\mathrm{p}} \varphi_{\mathrm{p}} \mathrm{Z}_{\mathrm{p}}+\mathrm{q}_{\mathrm{rs}} * \mathrm{O}_{\mathrm{rf}} \mathrm{U}_{\mathrm{pre}}\right.\right.$ $\left.Z_{\text {rain }}+\left(1-q_{\text {rs }}\right) \mathrm{O}_{\mathrm{rf}} \mathrm{U}_{\text {pre }} \mathrm{Z}_{\text {snow }}\right]$

$\mathrm{D}_{\mathrm{fb} \text { con }}=\mathrm{G}_{\mathrm{fb} \text { con }} Z_{\mathrm{f} \text { con }}$

$\mathrm{D}_{\mathrm{fb} \_\mathrm{dec}}=0.5^{*} \mathrm{G}_{\mathrm{fb}} \mathrm{dec}_{\mathrm{f}_{\mathrm{fdec}}}$

$\mathrm{D}_{\mathrm{rf}}=\mathrm{Z}_{\mathrm{f}} \mathrm{frc}_{\text {leaf }} \mathrm{V}_{\mathrm{f}} \mathrm{K}_{\mathrm{rf}}$

$\mathrm{D}_{\mathrm{rsp}}=\mathrm{k}_{\mathrm{sp}} \mathrm{V}_{\mathrm{sp}} \mathrm{Z}_{\mathrm{sp}}$

$D_{s p-a}=A_{s p} /\left(1 /\left(U_{s / a-b l} Z_{a}\right)+1 /\left(w f U_{s / a p s} Z_{a}\right)\right)$

$\mathrm{K}_{\mathrm{rse}}$ : Reaction rate in bulk sediment

$\mathrm{V}_{\mathrm{se}}$ : volume of sediment compartment

$\mathrm{A}_{s}$ : soil ground area

$\mathrm{L}_{\mathrm{w}}$ : leaching rate from soil to water

$\mathrm{K}_{\mathrm{rs}}$ : Reaction rate in bulk soil

$\mathrm{V}_{\mathrm{s}}$ : volume of soil

0.0002

$0.693 / \tau_{51 / 2} * 24$

$\tau_{\mathrm{s} 1 / 2}$ : degradation half-life in soil

$\mathrm{U}_{\mathrm{d}-\mathrm{g}}$ : dry gaseous deposition velocity to canopy

$\mathrm{m} / \mathrm{h}$

$\mathrm{A}_{\mathrm{f}}$ : forest ground area

$\mathrm{U}_{\mathrm{d}-\mathrm{p}}$ : dry particle deposition velocity to canopy

$\mathrm{m} / \mathrm{h}$

27 (deciduous)

3.4 (coniferous)

$\mathrm{Q}_{\mathrm{rf}}$ interception loss

$\mathrm{G}_{\mathrm{fb} \_ \text {con }}$ : litterfall rate of coniferous forest

$G_{f_{b} \_ \text {con: }}$ : litters

$\varphi_{\text {con }}$ : fraction of forest made up from coniferous

$\mathrm{V}_{\mathrm{f}}$ : volume of foliage compartmen

$\mathrm{K}_{\mathrm{r}}$ : first-order degradation rate in foliage

$\mathrm{k}_{\mathrm{sp}}$. reaction rate of contaminant in snowpack

$\mathrm{V}_{\mathrm{sp}}$ : volume of snowpack

$35 \%$

\section{$\mathrm{m}^{3}$ canopy $/ \mathrm{h}$}

$\mathrm{m}^{3}$ canopy/h

$\mathrm{U}_{\mathrm{s} / \mathrm{ab} \mathrm{b}}$ : mass transfer coefficient for air boundary $\mathrm{m} / \mathrm{h}$

layer above snow space

$\mathrm{A}_{\mathrm{sp}}$ : snowpack ground area

$\mathrm{B}_{\mathrm{a}}\left(\varphi_{\mathrm{a}}{ }^{10 / 3} / \varphi_{\mathrm{a}}+\varphi_{\mathrm{w}}\right)^{2} /\left(\log _{2} h_{s p}\right)$

$\mathrm{B}_{\mathrm{a}}$ : molecular diffusivity in air, $\mathrm{m}^{2} / \mathrm{h}$

$h_{\text {sp }}$ : height of snowpack, $\mathrm{m}^{3}$

$\mathrm{m}^{2}$

$\mathrm{D}_{\mathrm{a}-\mathrm{sp}}=\mathrm{D}_{\mathrm{sp} \mathrm{a}}+\mathrm{U}_{\mathrm{pre}} \mathrm{A}_{\mathrm{sp}} \mathrm{Z}_{\text {snow }}$

$\mathrm{D}_{\text {a-sp }}=\mathrm{D}_{\text {sp a }} \mathrm{U}_{\text {pre }} \mathrm{A}_{\text {sp }} Z_{\text {snow }}$
$\mathrm{D}_{\text {sp-s }}=\varphi_{\text {swe-sp }} h_{\text {sp_max }} A_{s} k_{\text {melt }} Z_{w}$

$\varphi_{\text {swesp: }}$ volume fraction of snow water equivalent in snowpack

$\mathrm{k}_{\text {melt }}$ : melting rate

$h_{\text {sp_max: }}$ maximum height of snowpack $\quad \mathrm{m}$

$\mathrm{D}_{\mathrm{sp}-\mathrm{w}}=\varphi_{\text {swe-sp }} h_{\text {sp max }} \mathrm{A}_{\mathrm{w}} \mathrm{k}_{\mathrm{melt}} \mathrm{Zw}$

$\mathrm{D}_{\text {sp-w }}=\varphi_{\text {swe-sp }} h_{\text {sp max }} A_{\text {w }} k_{\text {melt }} Z$
$D_{\text {spp-s }}=G_{\text {pf }} Z_{\mathrm{w}}+A_{s} \varphi_{\text {sp__ }} h_{\text {sp_max }} Z_{\text {om }}$

$\mathrm{G}_{\mathrm{pf}}$ : water remaining in snowpack when particle

flush occurs 
Table S10. Lists of parameters in the mass balance equations

\begin{tabular}{|c|c|c|c|c|}
\hline Parameters & Symbols of parameters & Units & Values or equations & References \\
\hline \multicolumn{5}{|l|}{ Fugacity } \\
\hline fugacity of pollutants in input air-mass to each cell & $f_{a_{i n}}$ & $\mathrm{~Pa}$ & 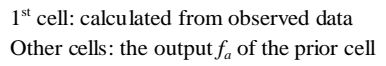 & \\
\hline fugacity of pollutants in air & $f_{a}$ & $\mathrm{~Pa}$ & & \\
\hline fugacity of pollutants in water & $f_{w}$ & $\mathrm{~Pa}$ & & \\
\hline fugacity of pollutants in soil & $f_{s}$ & $\mathrm{~Pa}$ & & \\
\hline fugacity of pollutants in foliage of deciduous forest & $f_{f_{\text {dec }}}$ & $\mathrm{Pa}$ & & \\
\hline fugacity of pollutants in foliage of coniferous forest & $f_{\text {con }}$ & $\mathrm{Pa}$ & & \\
\hline fugacity of pollutants in foliage of shrub & $f_{f_{s h}}$ & $\mathrm{~Pa}$ & & \\
\hline fugacity of pollutants in foliage of grassland & $f_{f_{\text {grass }}}$ & $\mathrm{Pa}$ & & \\
\hline fugacity of pollutants in the foliage of farmland & $f_{f_{f l}}$ & $\mathrm{~Pa}$ & & \\
\hline fugacity of pollutants in snowpack & $f_{s p}$ & $\mathrm{~Pa}$ & & \\
\hline fugacity of pollutants in soil under deciduous foliage & $f_{s_{d e c}}$ & $\mathrm{~Pa}$ & & \\
\hline fugacity of pollutants in soil under coniferous foliage & $f_{\text {son }}$ & $\mathrm{Pa}$ & & \\
\hline fugacity of pollutants in soil under shrub foliage & $f_{\text {srass }}$ & $\mathrm{Pa}$ & & \\
\hline fugacity of pollutants in soil of grassland & $f_{s_{s h}}$ & $\mathrm{~Pa}$ & & \\
\hline fugacity of pollutants in soil of farmland & $f_{s_{f l}}$ & $\mathrm{~Pa}$ & & \\
\hline fugacity of pollutants in sediment & $f_{\text {sed }}$ & $\mathrm{Pa}$ & & \\
\hline \multicolumn{5}{|l|}{ Environmental parameters } \\
\hline grid area & A & $\mathrm{m}^{2}$ & grid area & \\
\hline air ground area & $\mathrm{A}_{a}$ & $\mathrm{~m}^{2}$ & A & \\
\hline foliage ground area & $A_{f}$ & $\mathrm{~m}^{2}$ & $\mathrm{~A}^{*} \delta_{\mathrm{con}}\left(\right.$ or $\delta_{\mathrm{dec}}$ or $\delta_{\mathrm{sh}}$ or $\delta_{\mathrm{gl}}$ or $\left.\delta_{\mathrm{fl}}\right)$ & \\
\hline soil ground area & $A_{s}$ & $\mathrm{~m}^{2}$ & $\mathrm{~A}^{*}\left(\delta_{\mathrm{bs}}+\delta_{\mathrm{w}}+0.3 * \delta_{\mathrm{u}}\right)$ & \\
\hline snowpack ground area & $A_{\mathrm{sp}}$ & $\mathrm{m}^{2}$ & $\mathrm{~A}^{*} \delta_{\mathrm{sp}}$ & \\
\hline water ground area & $A_{w}$ & $\mathrm{~m}^{2}$ & $A^{*} \delta_{w}$ & \\
\hline stability of winter atmosphere relative to summer conditions & Fac $c_{\text {stability }}$ & & 3 & [13] \\
\hline stay constant of foliage in different seasons & $\mathrm{frc}_{\text {leaf }}$ & & 1 , when summer; 0.2 , when winter & \\
\hline air advection rate & $\mathrm{G}_{\mathrm{a}}$ & $\mathrm{m}^{3} / \mathrm{h}$ & & \\
\hline water remaining in snowpack when particle flush occurs & $\mathrm{G}_{\mathrm{pf}}$ & $\mathrm{m}^{3}$ & & \\
\hline atmospheric height & $\mathrm{h}_{\mathrm{a}}$ & M & 1000 & [35] \\
\hline surficial sediment depth & $h_{\text {sed }}$ & M & 0.05 & \\
\hline water depth & $\mathrm{h}_{\mathrm{w}}$ & M & 2 & \\
\hline maximum height of snowpack & $h_{s p \max }$ & M & observed data & \\
\hline mass fraction of organic carbon in soil & $\mathrm{mf}_{\mathrm{oc}}$ & $g / g$ & observed data & \\
\hline
\end{tabular}


mass fraction of organic matter in atmospheric particles

mass fraction of organic matter in soil

concentrations of $\mathrm{OH}$ radical in air

indicator of summer and winter

indicator of rain and snow

specific snow surface area

specific canopy volume for coniferous

specific canopy volume for deciduous

specific canopy volume for shrublands

specific canopy volume for grasslan

specific canopy volume for farmland

Temperature

density of atmospheric particles

volume of foliage compartment in coniferous

volume of foliage compartment in deciduous

volume of foliage compartment in shrublands

volume of foliage compartment in grassland

volume of foliage compartment in farmland

volume of soil

volume of sediment compartment

volume of snowpack

volume of water compartmen

wind-pumping factor

wind speed

depth of each soil layer

depth of agriculture soil layer

area fraction of water in each grid

area fraction of coniferous forest in each grid

area fraction of deciduous forest in each grid

area fraction of shrublands in each grid

area fraction of grasslands in each grid

area fraction of wetlands in each grid

area fraction of framlands in each grid

area fraction of urban regions in each grid

area fraction of snow in each grid

area fraction of barren soil in each grid

density of ice

density of octanol 
density of sediment

density of suspend particle in water

density of snow

density of foliage

volume fraction of air in soil

volume fraction of air in wetland soil

volume fraction of water in sediment

volume fraction of mineral matter in soil

volume fraction of organic matter in soi

volume fraction of air in snowpack

volume fraction of organic matter in snowpack

snow porosity

volume fraction of water in snowpack

volume fraction of water in so

volume fraction of water in wetland soil

volume fraction of snow water equivalent in snowpack

volume fraction of aerosols in air

\section{Physicochemical parameter}

foliage-air partitioning coefficien

interfacial sorption coefficien

Henry's law constan

mineral matter/water partitioning coefficient

octanol-air partitioning coefficien

(soil) organic carbon-water partitioning coefficient

octanol-water partitioning coefficien

gas-particle partioning coefficient

gas-particle partioning coefficien

Sediment/water partitioning coefficient

Suspension matter/water partitioning coefficien

ideal gas constant

degradation half-life in

degradation half-life in foliage

degradation half-life in soil

degradation half-life in sediment

degradation half-life in water (snow)

molar volume

\begin{tabular}{|c|c|}
\hline $\mathrm{g} / \mathrm{m}^{3}$ & 1540000 \\
\hline $\mathrm{g} / \mathrm{m}^{3}$ & 1500000 \\
\hline $\mathrm{kg} / \mathrm{L}$ & 0.433 \\
\hline \multirow[t]{14}{*}{$\mathrm{g} / \mathrm{m}^{2}$} & 250 \\
\hline & 0.26 \\
\hline & $\varphi_{\mathrm{sel}} / 2$ \\
\hline & 0.43 \\
\hline & $\left(1-\varphi_{\mathrm{sa}}-\varphi_{\mathrm{sw}}\right) /\left(1+2500 \mathrm{mf}_{\mathrm{som}} /\left(1000 *\left(1-\mathrm{mf}_{\mathrm{som}}\right)\right)\right)$ \\
\hline & $1-\left(\varphi_{\mathrm{sa}}+\varphi_{\mathrm{sw}}+\varphi_{\mathrm{smm}}\right)$ \\
\hline & $\varphi_{\text {sp_pore }}-\varphi_{\text {SP_w }}$ \\
\hline & $\left(1-\varphi_{\text {sp_pore }}-\varphi_{\text {sp_ } \_}\right) * m f_{p \_o}$ \\
\hline & $1-\rho_{\text {snow }} / \rho_{\text {ice }}$ \\
\hline & 0.03 \\
\hline & 0.29 \\
\hline & $\varphi_{\mathrm{sw}} * 2$ \\
\hline & 0.1 \\
\hline & $6^{*} 10^{-11}$ \\
\hline
\end{tabular}

$14 \mathrm{Koa}^{0.76}$ for deciduous; $38 \mathrm{Koa}^{0.09}$ for coniferous $\log \mathrm{K}_{\mathrm{i}=}=3.60 \sum \alpha_{2}{ }^{\mathrm{H}}+5.11 \sum \beta_{2}{ }^{\mathrm{H}}+0.635 \log \mathrm{L}^{16}-8.47$

$\mathrm{mol} /\left(\mathrm{m}^{2}\right.$ surface $) / \mathrm{mol} /\left(\mathrm{m}^{3}\right.$ air $)$ $\mathrm{Pa} \mathrm{m} \mathrm{m}^{3} / \mathrm{mo}$ See Table S

See Table S7

$0.41 \mathrm{~K}_{\text {ow }}$

See Table S7

$\operatorname{logKp}=\operatorname{logKoa}+\mathrm{mf}_{\mathrm{p} \_\mathrm{o}}-11.91$

$\mathrm{K}_{\mathrm{p}} * \mathrm{TSP}^{2} * 10^{-6}$

$0.033 \mathrm{~K}_{\text {o }} \mathrm{P}_{\mathrm{se}}$

$\mathrm{mf}_{\mathrm{oc}} \mathrm{K}_{\mathrm{oc}} \rho_{\mathrm{sus}}$

8.314

See Table S7

See Table $\mathrm{S} 7$

See Table S7

See Table S7

See Table S

See Table S7
[13] 


\section{Environmental behavior parameters}

molecular diffusivity in air

molecular diffusivity in water

litterfall rate of coniferous forest

litterfall rate of deciduous forest

rate of sedimentation

reaction rate in air

first-order degradation rate in foliage

reaction rate in bulk sediment

reaction rate of contaminant in snowpack

reaction rate in bulk water

reaction rate in bulk soil

rate of resuspension

MTC for diffusion in the air pore space in bare soil

MTC for diffusion in the air pore space in agricultural soi

MTC for diffusion in the air pore space in forest sol

mass transfer coefficient for the atmospheric boundary layer above the air-soil interface

melting rate

mass transfer coefficient for solid phase diffusion in agricultural soils

mass transfer coefficient for solid phase diffusion in forest soils

MTC for diffusion across benthic boundary laye

ic boundary layer over wate

mass transfer coefficient for the stagnant water layer at the air-water interface

mass transfer coefficient for diffusion in the water pore space

leaching rate from soil to water

particle scavenging ratio for rain

interception loss

particle scavenging ratio for snow

average time a needle stays on tree

dry gaseous deposition velocity to canopy

dry particle deposition velocity to canopy

dry deposition rate under forest canopy

dry deposition rate under agricultural foliage

dry deposition rate to water

dry deposition rate in bare soil

precipitation rate

\begin{tabular}{|c|c|}
\hline $\mathrm{B}_{\mathrm{a}}$ & $\mathrm{m}^{2} / \mathrm{h}$ \\
\hline$B_{w}$ & $\mathrm{~m}^{2} / \mathrm{h}$ \\
\hline $\mathrm{G}_{\mathrm{ft}_{\mathrm{f} \_ \text {con }}}$ & $\mathrm{m}^{3}$ canopy $/ \mathrm{h}$ \\
\hline $\mathrm{G}_{\mathrm{fb} \_ \text {dec }}$ & $\mathrm{m}^{3}$ canopy $/ \mathrm{h}$ \\
\hline $\mathrm{K}_{\mathrm{dw}}$ & $\mathrm{m} / \mathrm{a}$ \\
\hline $\mathrm{K}_{\mathrm{ra}}$ & $h^{-1}$ \\
\hline$K_{\mathrm{rf}}$ & $\mathrm{h}^{-1}$ \\
\hline$K_{\text {rse }}$ & $\mathrm{h}^{-1}$ \\
\hline $\mathrm{K}_{\mathrm{rsp}}$ & $\mathrm{h}^{-1}$ \\
\hline $\mathrm{K}_{\mathrm{rw}}$ & $\mathrm{h}^{-1}$ \\
\hline$K_{r s}$ & $\mathrm{~h}^{-1}$ \\
\hline $\mathrm{K}_{\mathrm{se}}$ & $\mathrm{m} / \mathrm{a}$ \\
\hline $\mathrm{k}_{\mathrm{a} \_ \text {pore }}$ & $\mathrm{m} / \mathrm{h}$ \\
\hline $\mathrm{k}_{\text {a_pore_agr }}$ & $\mathrm{m} / \mathrm{h}$ \\
\hline$k_{\text {a-pore_f }}$ & $\mathrm{m} / \mathrm{h}$ \\
\hline $\mathrm{k}_{\mathrm{as}}$ & $\mathrm{m} / \mathrm{h}$ \\
\hline $\mathrm{k}_{\text {melt }}$ & $h^{-1}$ \\
\hline $\mathbf{k}_{\text {solid_agri }}$ & $\mathrm{m} / \mathrm{h}$ \\
\hline $\mathrm{k}_{\text {solid_f }}$ & $\mathrm{m} / \mathrm{h}$ \\
\hline $\mathrm{k}_{\mathrm{sw}}$ & $\mathrm{m} / \mathrm{h}$ \\
\hline $\mathrm{k}_{\mathrm{va}}$ & $\mathrm{m} / \mathrm{h}$ \\
\hline $\mathrm{k}_{\mathrm{vw}}$ & $\mathrm{m} / \mathrm{h}$ \\
\hline $\mathrm{k}_{\mathrm{w} \text { _pore }}$ & $\mathrm{m} / \mathrm{h}$ \\
\hline $\mathrm{L}_{\mathrm{w}}$ & $\mathrm{m} / \mathrm{h}$ \\
\hline$Q_{r}$ & \\
\hline $\mathrm{Q}_{\mathrm{rf}}$ & \\
\hline $\mathrm{Q}_{\mathrm{s}}$ & \\
\hline$t_{\text {needle }}$ & year \\
\hline $\mathrm{U}_{\mathrm{d}-\mathrm{g}}$ & $\mathrm{m} / \mathrm{h}$ \\
\hline $\mathrm{U}_{\mathrm{d}-\mathrm{p}}$ & $\mathrm{m} / \mathrm{h}$ \\
\hline$U_{p f f}$ & $\mathrm{~m} / \mathrm{h}$ \\
\hline $\mathrm{U}_{\mathrm{p} \_\mathrm{a}}$ & $\mathrm{m} / \mathrm{h}$ \\
\hline $\mathrm{U}_{\mathrm{p}_{-} \mathrm{w}}$ & $\mathrm{m} / \mathrm{h}$ \\
\hline $\mathrm{U}_{\mathrm{p}}$ & $\mathrm{m} / \mathrm{h}$ \\
\hline $\mathrm{U}_{\text {pre }}$ & $\mathrm{m} / \mathrm{h}$ \\
\hline
\end{tabular}

$0.186 * 10^{0.0283 T} /\left(\mathrm{V}_{\mathrm{m}}{ }^{0.21}\right)$
$4.864 * 10^{-3 /} /\left(\mu^{0.005} \mathrm{~V}_{\mathrm{m}}{ }^{1.3}\right)$

$\mathrm{V}_{\mathrm{f}} /\left(\mathrm{t}_{\text {neese }} * 365 * 24\right)$

$0.8 \mathrm{~V}_{\mathrm{f}} /(90 * 24)$

0.0004

$0.693 * 24 /\left(\tau_{\mathrm{a} 12} *[\mathrm{OH}]\right)$

$0.693 / \tau_{512} * 24$

$0.693 / \tau_{112} * 24$

$0.693 / \tau_{112} * 24$

$0.693 / \tau_{112} * 24$

$0.693 / \tau_{\mathrm{s} 12} * 24$

0.0001

$0.8 \quad$ [7]

2.08

0.416

1 [7]

1/(33days*24 hours/day) [15]

0.01

0.005

0.01

3

$0.03-[7]$

$8^{*} 10^{-5}$

$8 * 10^{-5}$

68000

$35 \%$

$10^{5}$

5

64.8 for deciduous; 21.05 for coniferous Half of Wania and

McLachlan's data ${ }^{13}$

$\begin{array}{ll}13.5 \text { for deciduous; } 1.7 \text { for coniferous } & \begin{array}{l}\text { Half of Wania and } \\ \text { McLachlan's data }\end{array}\end{array}$

0.206

$[14]$

1.03

1.03

[14]

Half of Mackay's value ${ }^{7}$ 
mass transfer coefficient for air boundary layer above snow

mass transfer coefficient for air-filled pore space

diffusion length in sedimen
$\mathrm{U}_{\text {sa-bl }} \quad \mathrm{m}$

Sta-ps $\quad \mathrm{m} / \mathrm{h}$

M $\mathrm{wf} * \mathrm{U}_{\mathrm{s}-\mathrm{ps}} / \mathrm{U}_{\mathrm{sip}-\mathrm{hl}}=1$

$\mathrm{B}_{\mathrm{a}}\left(\varphi_{\text {s__a }}{ }^{103 /} / \varphi_{\text {s__a }}+\varphi_{\text {sp_ }}\right)^{2} /\left(\log _{2} h_{\text {sp }}\right)$

0.005
[15] 
(a)

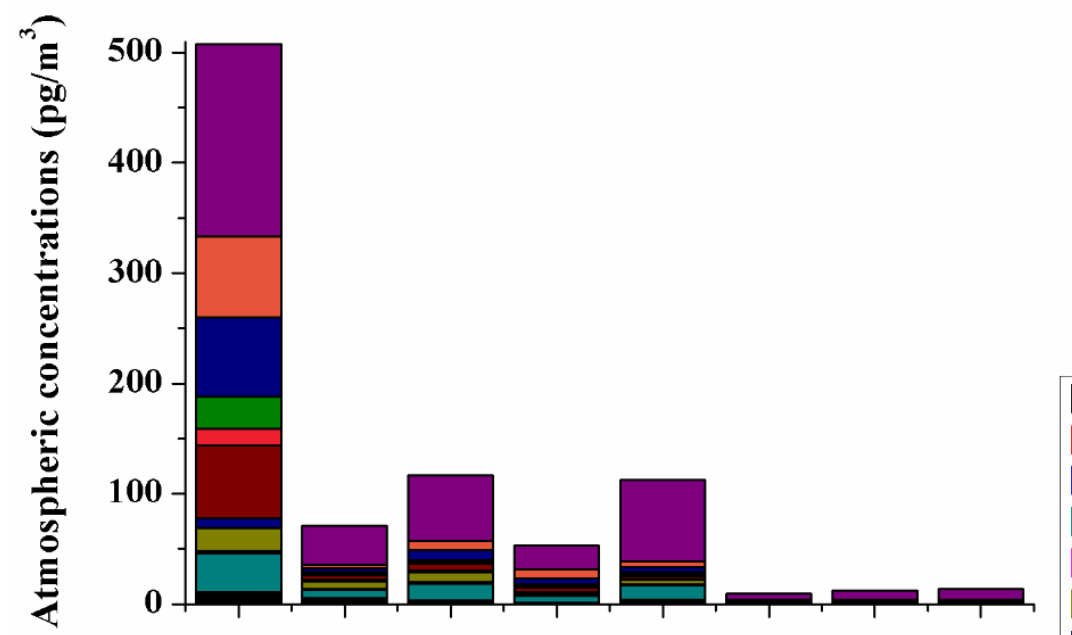

(b)

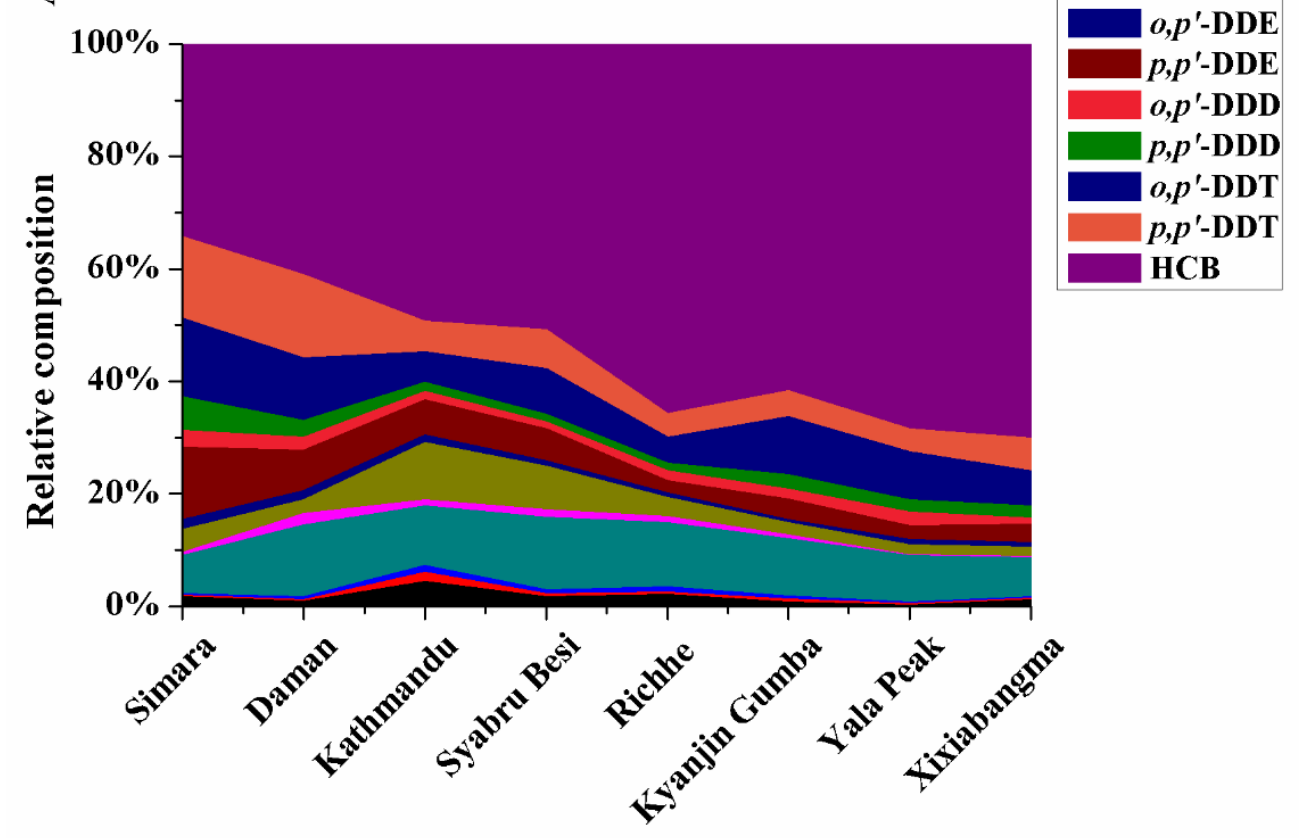

Figure S6. (a) Average absolute concentrations of five seasonal samples and (b) relative composition of target pollutants in the atmosphere along the transect from low-land to high-altitude regions in the Himalayas. 
(a) Simara

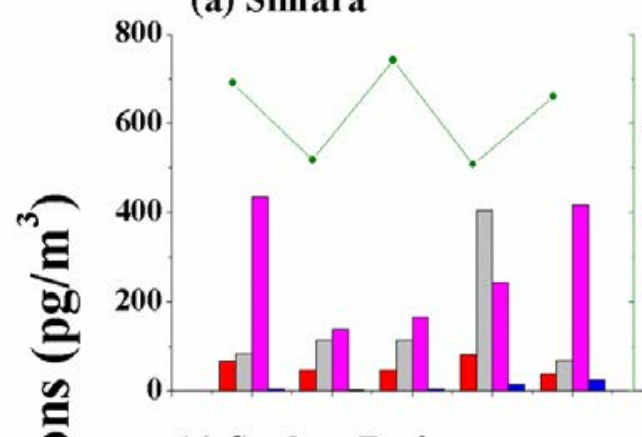

(b) Kathmandu

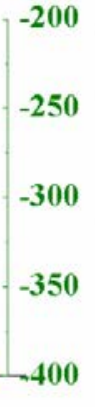

-200
-250
-300
-350
400

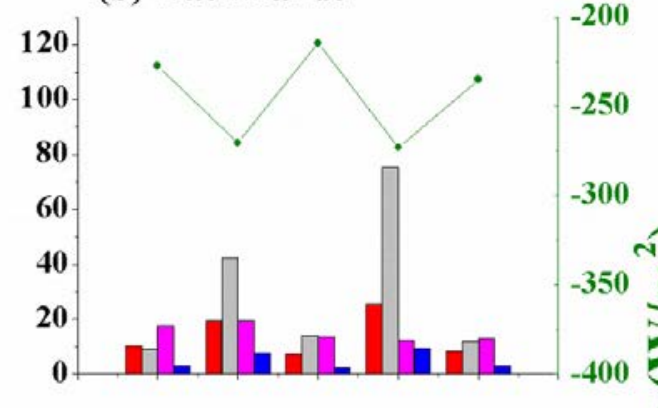

(d) Richhe

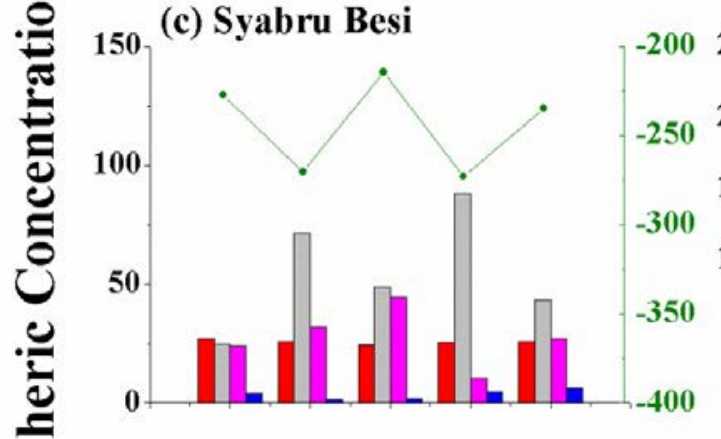

के Kyanjin Gumba

$\stackrel{\Xi}{\varrho}$
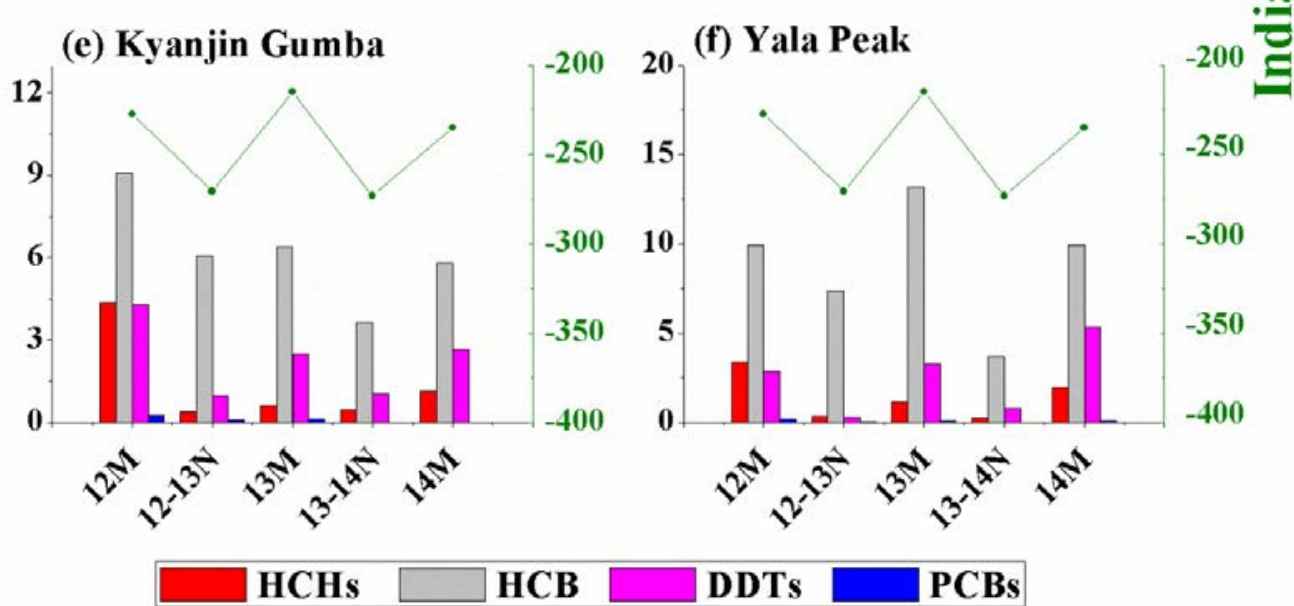

$10-300$
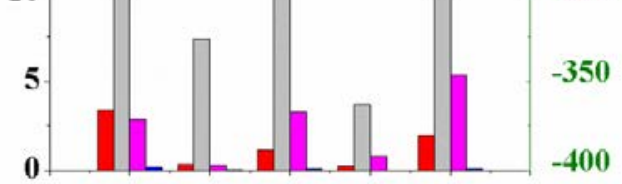

$x^{2} x^{3} \hat{3}^{2} x^{2} x^{2}$

DDTs

PCBs

Figure S7. Seasonal variations of atmospheric POP concentrations and changes in the Indian monsoon index during the sampling periods. 


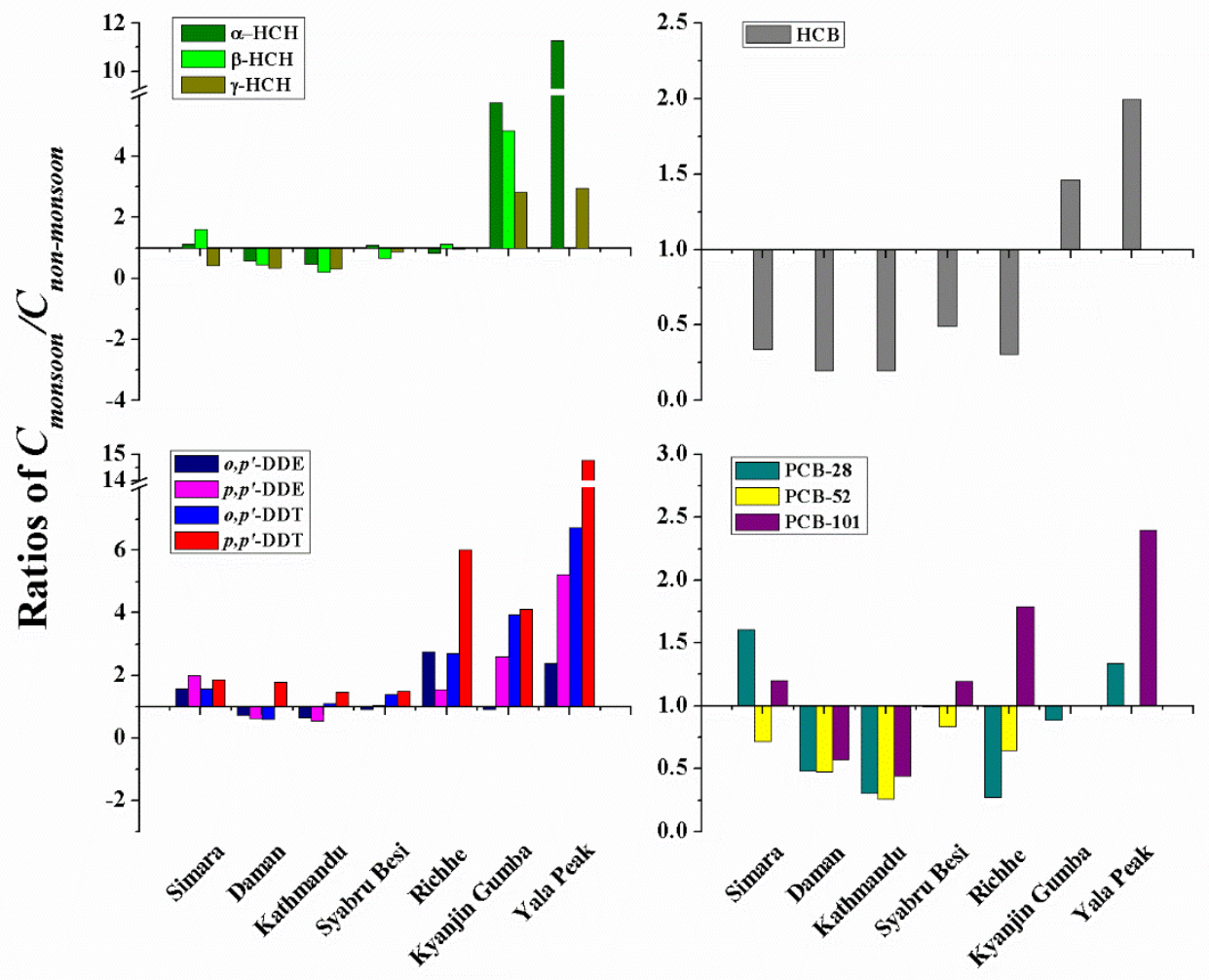

Figure S8. The ratios of concentrations during the monsoon seasons to those during the non-monsoon seasons 

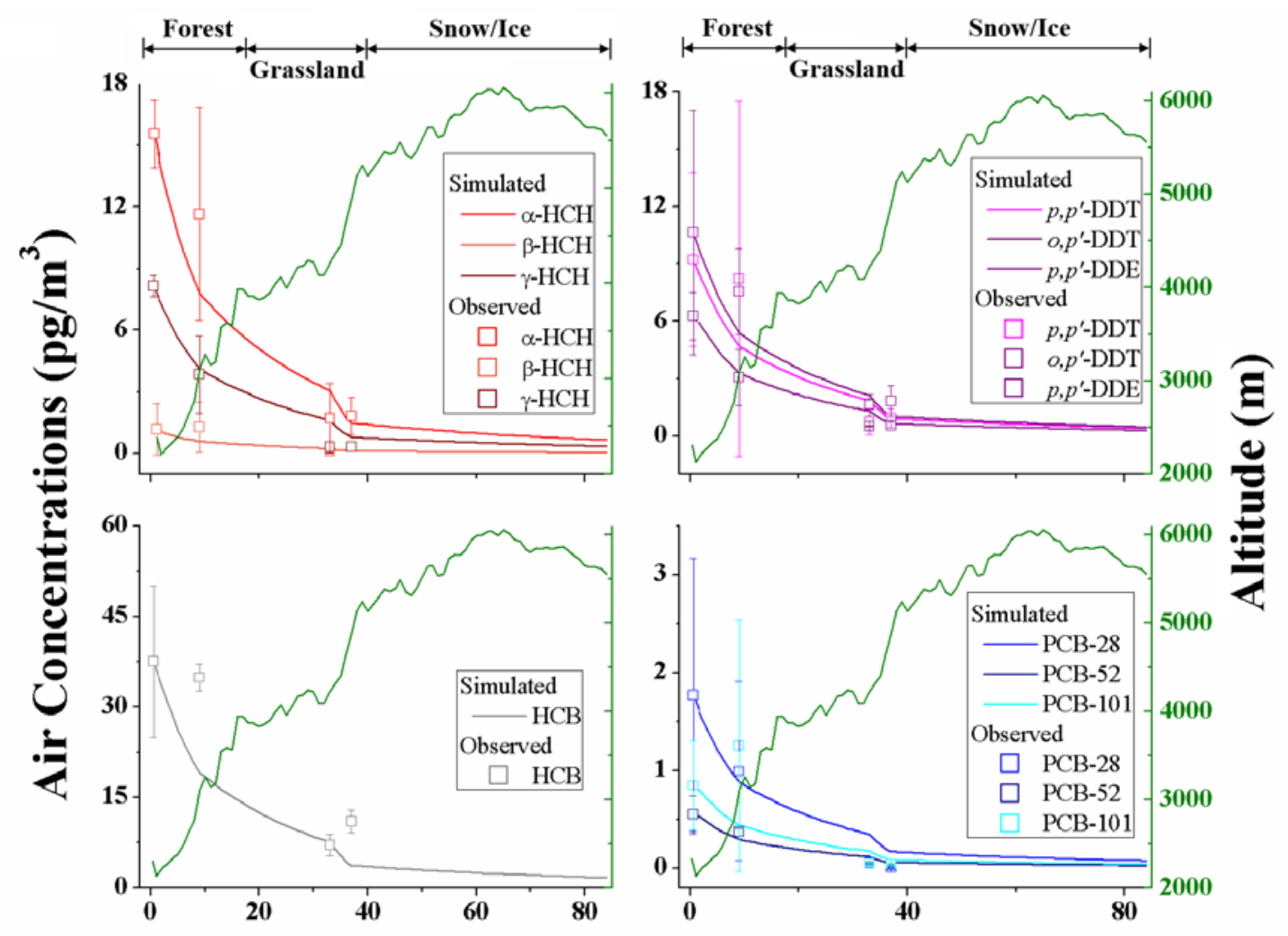

Distance from Syabru Besi $(\mathbf{k m})$

Figure S9. Observed and simulated concentrations of atmospheric POPs along the Himalayan slope transect from Syabru Besi to the Xixiabangma during the monsoon season. In these figures, the $\mathrm{x}$ axis is the distance from Syabru Besi (the starting cell), green lines indicate the average altitude of each cell, and open squares designate concentrations observed at a sampling site. 

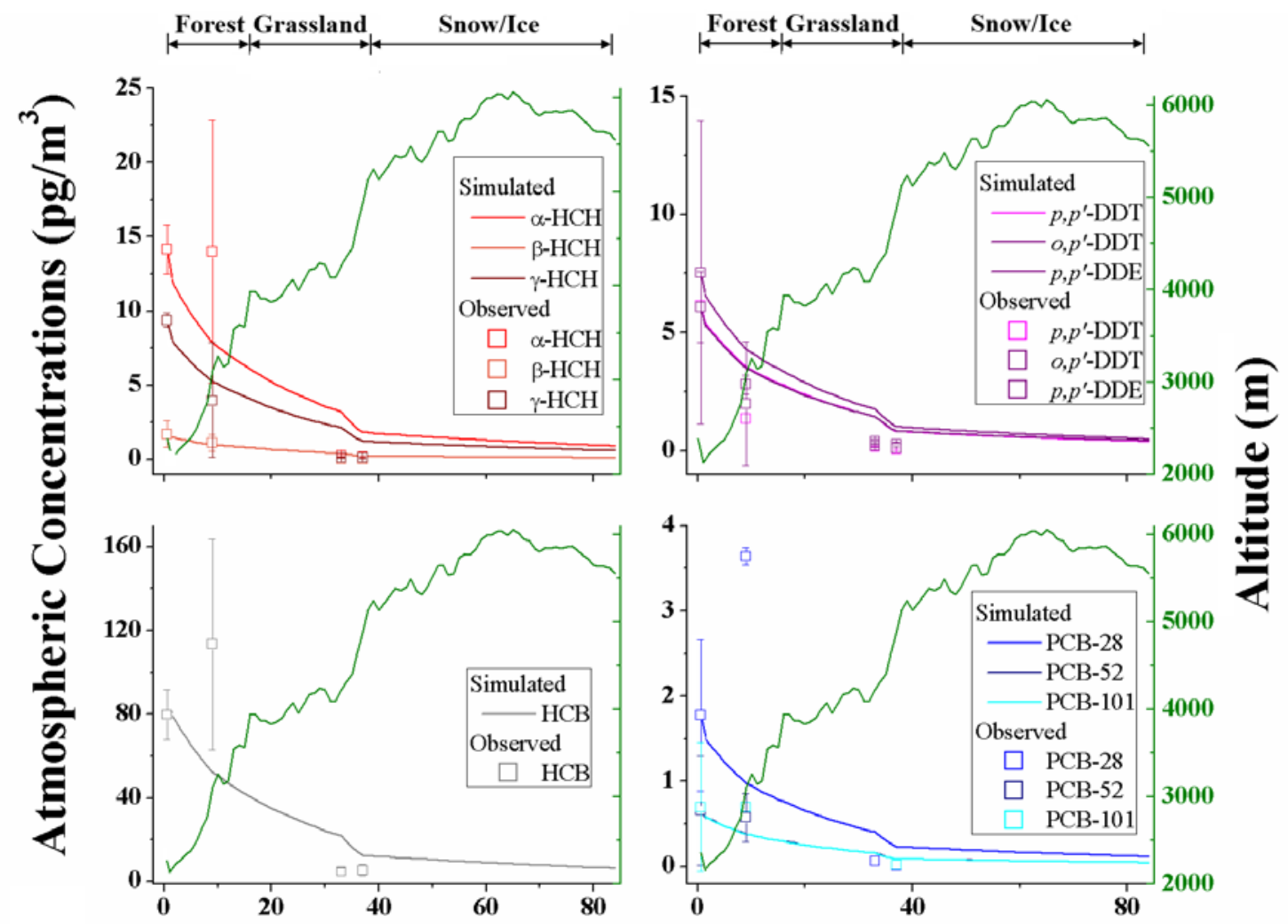

Distance from Syabru Besi $(\mathbf{k m})$

Figure S10. Observed and simulated concentrations of atmospheric POPs along the Himalayan slope transect from Syabru Besi to the Xixiabangma during the non-monsoon season. In these figures, the $\mathrm{x}$-axis is the distance from Syabru Besi (the starting cell), green lines indicate the average altitude of each cell, and open squares designate concentrations observed at a sampling site. 

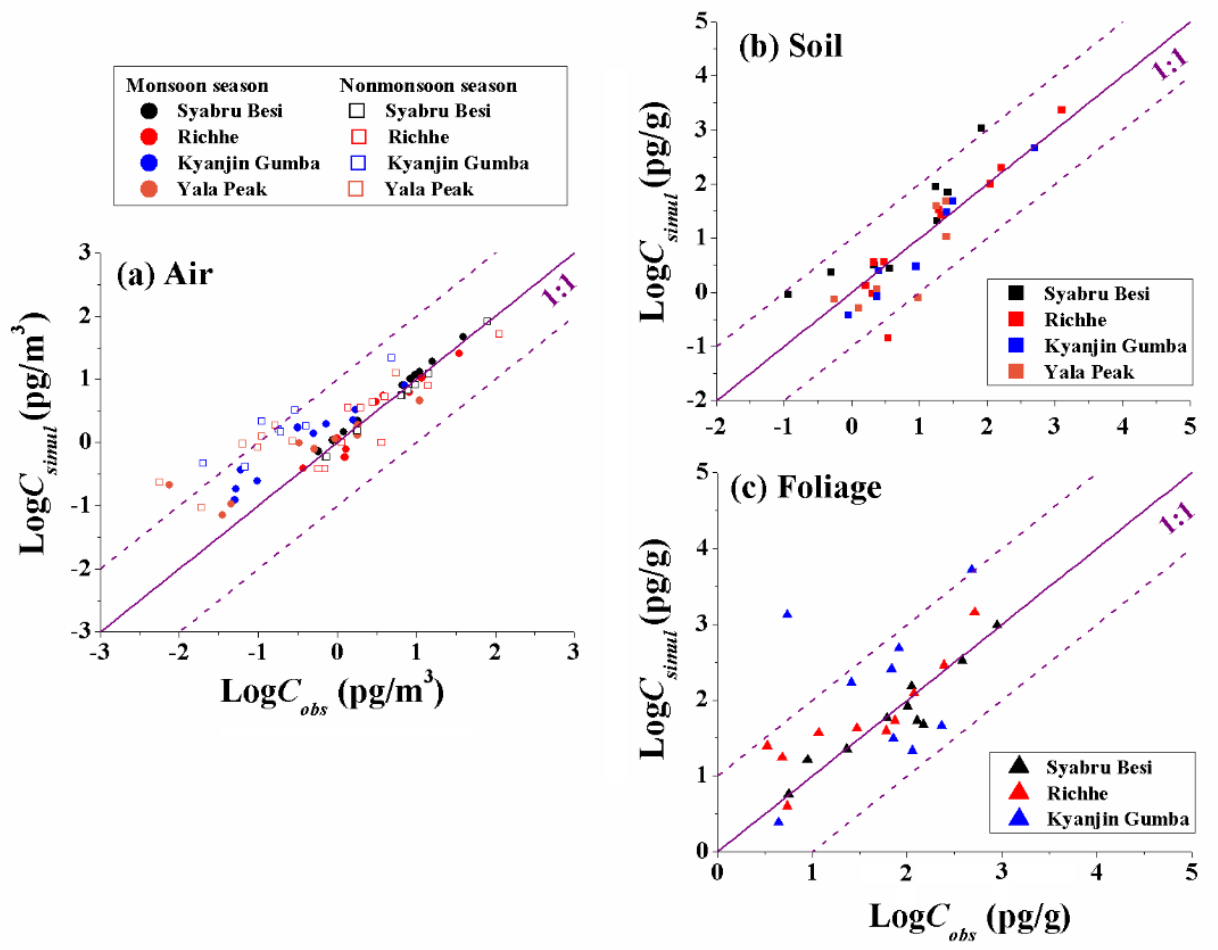

Figure S11. Comparison between simulated and observed concentrations of organochlorine compounds in (a) air, (b) soil, and (c) foliage along the southern slope of the Himalayas
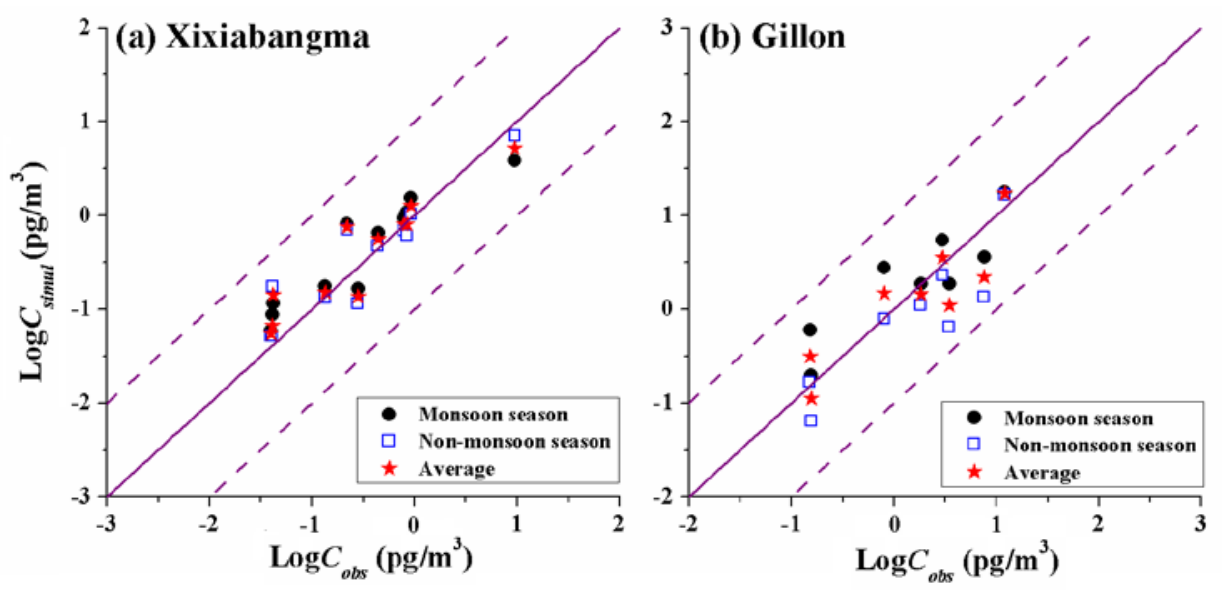

Figure S12. Comparison between simulated and observed atmospheric concentrations on the northern slope of the Himalayas: (a) Xixiabangma site; and (b) Gillon 


\section{Text S4. Model evaluation}

\section{S4-1 Comparisons between the observed and the simulated values}

In order to evaluate the performance of our model, observed and simulated values were compared. On the southern slope, the concentrations in air (this study), soil, and foliage (Reference 10) observed at the sampling sites on Syabru Besi, Richhe, Kyanjin Gumba, and Yala Peak were compared with the concentrations simulated for cells 1, 9, 33, and 37 of the model for transport along slopes (Figure S9-10). Differences between observed and simulated data in air and soil are within one order of magnitude (Figure S11a and S11b), indicating a good match. Some simulated data points for foliage in Kyanjin Gumba are 10 times higher than the observed data (Figure S11c). Kyanjin Gumba is located in a high-altitude region at the border between shrub and grassland ecosystems. The higher discrepancy may be caused by a shortage of observed data in shrub or grass leaves. Therefore, we should be cautious when we discuss the simulated pattern of POPs in shrub or grass ecosystem.

Atmospheric concentrations measured on the northern slope of the Himalayas (Gillon ${ }^{1}$ and Mt. Xixiabangma) were used to evaluate the model. Simulated and observed concentrations are similar (Figure S12), suggesting that the model can be used to study trans-Himalayan atmospheric transport.

\section{S4-2 Uncertainties of the model}

Uncertainties in model predictions are the results of uncertain and variable input parameters and missing/misrepresented processes. In this section, we try to quantify the uncertainties from the input parameters. Two compounds, $\alpha-\mathrm{HCH}$ and $o, p$ '-DDT, representing low and high molecular weight pollutants, respectively, are used to investigate the uncertainties in the presented model calculations. In fugacity models, the parameters include physicochemical parameters and environmental parameters (Table S7-S10). Some environmental parameters (e.g. areas of different lands) were derived from remote sensing products, which have small relative errors (a few meters for values of thousands of meters).

Some parameters, such as $K_{H}, K_{o a}$, and half-lives of chemicals, are basic physicochemical properties, which are used to calculate other physicochemical properties (e.g. $K_{o c}, K_{p}$, and others).

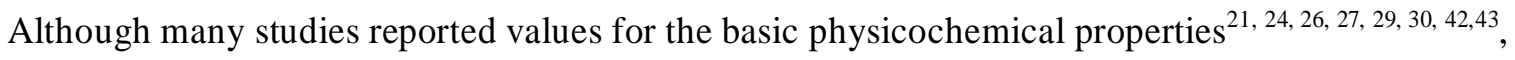
these measurements may be reasonably expected to have a $30 \%$ uncertainty $^{21}$. When the basic physicochemical parameters are varied by $\pm 30 \%$ accordingly, the impact on the output values for 
atmospheric concentrations, transport fluxes, air-foliage exchange, air-soil exchange, and rainfall fluxes, which are the focus of this study, were minor (Table S11).

From Table S11, it can be found that the model outputs in this study are most sensitive to wind direction and the atmospheric concentration assumed to prevail at the bottom of the transect. Transport fluxes, air-foliage exchange, and air-soil exchange varied from 49\%-193\% when the parameter of wind direction (fraction of the air-mass trajectories that align with the transect in Table S11, estimated as in equation (3) in the main text) changed 30\%. Although the HYSPLIT model may introduce uncertainties when calculating trajectories, $\mathrm{Su}$ et al. $^{44}$ suggested that these uncertainties can be ignored when referring to the transport to the North, Northeast, or West in the mid-latitude of Asia. Therefore, we assumed that the uncertainties from the calculations are likely lower than 30\%. While all the output data changed with similar fluctuations of the input concentrations of air pollutants ( $C_{a_{-} \text {initial }}$ in Table S11), except the air-soil exchange. The input concentrations of air pollutants are derived from observations, which were conducted as described in section 'Quality assurance/quality control (QA/QC)', and which are estimated to have an error of less than $30 \%$ (Table S4).

Air-soil exchange is influenced sensitively by at least six factors (half-lives, temperature, $r_{n}$, total organic carbons in soil, Ca_initial, and input soil concentrations, Table S11). Except temperature, 30\% variations of other factors will introduce $150 \%-240 \%$ variations of air-soil exchange for small molecular weight pollutants (e.g. $\alpha-\mathrm{HCH}$ in Table S11). However, the variations of large molecular weight pollutants (o,p'-DDT as an example in Table S11) are only 40\%-70\% when $r_{n}$ and $C_{a_{-}}$initial changed at the levels of $\pm 30 \%$. The large uncertainties implied that we should treat the results of air-soil exchange cautiously. Therefore, the discussion of this study won't focus on the air-surface exchange. 
Table S11. Sensitivity analysis of selected parameters in the model

\begin{tabular}{|c|c|c|c|c|c|c|c|c|c|c|c|c|}
\hline \multirow{2}{*}{\multicolumn{2}{|c|}{ Parameters }} & \multirow{3}{*}{$\begin{array}{c}\text { Changes of } \\
\text { parameters } \\
+30 \%\end{array}$} & \multirow{2}{*}{\multicolumn{2}{|c|}{ Air concentration }} & \multirow{2}{*}{\multicolumn{2}{|c|}{ Transport flux }} & \multirow{2}{*}{\multicolumn{2}{|c|}{ Air-Foliage exchange }} & \multirow{2}{*}{\multicolumn{2}{|c|}{ Air-soil exchange }} & \multirow{2}{*}{\multicolumn{2}{|c|}{ Rainfall flux }} \\
\hline & & & & & & & & & & & & \\
\hline Property & $K_{H}$ & & $\begin{array}{c}\boldsymbol{\alpha}-\mathbf{H C H} \\
-0.003 \%\end{array}$ & $\begin{array}{c}\boldsymbol{o , p} \text {-DDT } \\
-0.003 \%\end{array}$ & $\begin{array}{r}\boldsymbol{\alpha}-\mathbf{H C H} \\
-0.01 \%\end{array}$ & $\begin{array}{r}\boldsymbol{o , p} \text { '-DDT } \\
-0.01 \%\end{array}$ & $\begin{array}{l}\boldsymbol{\alpha}-\mathrm{HCH} \\
-0.004 \%\end{array}$ & $\begin{array}{r}\boldsymbol{o , p} \text { '-DDT } \\
0.02 \%\end{array}$ & $\begin{array}{r}\boldsymbol{\alpha - H C H} \\
0.00 \%\end{array}$ & $\begin{array}{r}\boldsymbol{o}, \boldsymbol{p} \text { '-DDT } \\
0.00 \%\end{array}$ & $\begin{array}{c}\boldsymbol{\alpha - H C H} \\
-0.001 \%\end{array}$ & $\begin{array}{c}\begin{array}{c}\text { o,p'- } \\
\text { DDT }\end{array} \\
-0.001 \%\end{array}$ \\
\hline & & $-30 \%$ & $-0.003 \%$ & $-0.003 \%$ & $-0.01 \%$ & $-0.01 \%$ & $-0.004 \%$ & $0.02 \%$ & $0.00 \%$ & $0.00 \%$ & $-0.001 \%$ & $-0.001 \%$ \\
\hline & $K_{o a}$ & $+30 \%$ & $-0.003 \%$ & $-0.003 \%$ & $-0.01 \%$ & $-0.01 \%$ & $0.13 \%$ & $0.17 \%$ & $0.000 \%$ & $-0.001 \%$ & $-0.002 \%$ & $-0.002 \%$ \\
\hline & & $-30 \%$ & $-0.003 \%$ & $-0.002 \%$ & $-0.01 \%$ & $-0.01 \%$ & $-0.18 \%$ & $-0.18 \%$ & $-0.001 \%$ & $0.001 \%$ & $-0.001 \%$ & $-0.001 \%$ \\
\hline & $\tau$ & $+30 \%$ & $-0.02 \%$ & $-0.02 \%$ & $-0.07 \%$ & $-0.06 \%$ & $4.12 \%$ & $3.78 \%$ & $-157.91 \%$ & $7.86 \%$ & $-0.01 \%$ & $-0.02 \%$ \\
\hline & & $-30 \%$ & $0.02 \%$ & $0.02 \%$ & $0.07 \%$ & $0.06 \%$ & $-4.12 \%$ & $-3.78 \%$ & $241.63 \%$ & $-14.56 \%$ & $0.01 \%$ & $0.02 \%$ \\
\hline \multirow[t]{8}{*}{ Climate } & $T$ & $+30 \%$ & $0.004 \%$ & $0.008 \%$ & $0.01 \%$ & $0.02 \%$ & $6.26 \%$ & $3.47 \%$ & $29.18 \%$ & $-9.94 \%$ & $-21.38 \%$ & $-14.44 \%$ \\
\hline & & $-30 \%$ & $-0.004 \%$ & $-0.011 \%$ & $-0.01 \%$ & $-0.03 \%$ & $-5.58 \%$ & $-3.00 \%$ & $24.93 \%$ & $7.43 \%$ & $20.68 \%$ & $10.83 \%$ \\
\hline & $\mathrm{Pr}$ & $+30 \%$ & $-0.003 \%$ & $-0.003 \%$ & $-0.01 \%$ & $-0.01 \%$ & $-0.004 \%$ & $0.02 \%$ & $0.00 \%$ & $0.00 \%$ & $-0.001 \%$ & $-0.001 \%$ \\
\hline & & $-30 \%$ & $-0.003 \%$ & $-0.003 \%$ & $-0.01 \%$ & $-0.01 \%$ & $-0.004 \%$ & $0.02 \%$ & $0.00 \%$ & $0.00 \%$ & $-0.001 \%$ & $-0.001 \%$ \\
\hline & $v$ & $+30 \%$ & $0.04 \%$ & $0.04 \%$ & $30.11 \%$ & $30.12 \%$ & $0.12 \%$ & $0.13 \%$ & $-0.16 \%$ & $0.06 \%$ & $0.02 \%$ & $0.03 \%$ \\
\hline & & $-30 \%$ & $-0.08 \%$ & $-0.09 \%$ & $-30.13 \%$ & $-30.14 \%$ & $-0.23 \%$ & $-0.19 \%$ & $0.30 \%$ & $-0.11 \%$ & $-0.05 \%$ & $-0.06 \%$ \\
\hline & $r_{n}$ & $+30 \%$ & $50.32 \% *$ & $50.36 \%$ & $125.49 \%$ & $125.65 \%$ & $121.37 \%$ & $124.11 \%$ & $-192.87 \%$ & $67.75 \%$ & $36.72 \%$ & $34.35 \%$ \\
\hline & & $-30 \%$ & $-36.36 \% * *$ & $-36.37 \%$ & $-66.77 \%$ & $-66.83 \%$ & $-63.22 \%$ & $-64.45 \%$ & $170.52 \%$ & $-48.83 \%$ & $-32.42 \%$ & $-30.73 \%$ \\
\hline \multirow{4}{*}{$\begin{array}{l}\text { Surface } \\
\text { ground }\end{array}$} & TOC & $+30 \%$ & $-0.02 \%$ & $-0.01 \%$ & $-0.06 \%$ & $-0.03 \%$ & $-0.05 \%$ & $0.002 \%$ & $-150.66 \%$ & $7.69 \%$ & $-0.01 \%$ & $-0.005 \%$ \\
\hline & & $-30 \%$ & $0.01 \%$ & $0.01 \%$ & $0.06 \%$ & $0.03 \%$ & $0.06 \%$ & $0.06 \%$ & $225.78 \%$ & $-14.23 \%$ & $0.01 \%$ & $0.004 \%$ \\
\hline & $s V_{f}$ & $+30 \%$ & $-0.01 \%$ & $-0.02 \%$ & $-0.04 \%$ & $-0.06 \%$ & $-1.58 \%$ & $0.62 \%$ & $-26.22 \%$ & $7.36 \%$ & $32.31 \%$ & $20.35 \%$ \\
\hline & & $-30 \%$ & $0.001 \%$ & $0.01 \%$ & $-0.004 \%$ & $0.02 \%$ & $-4.19 \%$ & $-3.83 \%$ & $-0.02 \%$ & $0.02 \%$ & $0.003 \%$ & $0.01 \%$ \\
\hline Initial & Ca_initial & $+30 \%$ & $29.98 \%$ & $29.99 \%$ & $29.92 \%$ & $29.96 \%$ & $29.93 \%$ & $30.00 \%$ & $-180.53 \%$ & $40.20 \%$ & $29.99 \%$ & $29.99 \%$ \\
\hline input & & $-30 \%$ & $-29.99 \%$ & $-29.99 \%$ & $-29.99 \%$ & $-29.94 \%$ & $-29.94 \%$ & $-29.96 \%$ & 180.53\% & $-40.20 \%$ & $-29.99 \%$ & $-30.00 \%$ \\
\hline
\end{tabular}




\begin{tabular}{rrrrrrrrrrrr}
$\boldsymbol{C}_{\text {s_initial }}$ & $\mathbf{+ 3 0 \%}$ & $0.01 \%$ & $0.01 \%$ & $0.05 \%$ & $0.02 \%$ & $0.06 \%$ & $0.05 \%$ & $210.53 \%$ & $-10.20 \%$ & $0.005 \%$ & $0.003 \%$ \\
& $-\mathbf{3 0 \%}$ & $-0.02 \%$ & $-0.01 \%$ & $-0.08 \%$ & $-0.04 \%$ & $-0.07 \%$ & $-0.004 \%$ & $-210.53 \%$ & $10.20 \%$ & $-0.01 \%$ & $-0.01 \%$ \\
\hline
\end{tabular}

*: Red font labels parameters with a high influences on results (> 40\% variations of output data with 30\% variations of input parameter)

**: Green font labels parameters with some influence on results ( 30\% variations of output data with 30\% variations of input parameter) 


\begin{tabular}{|l|l|l|}
\hline \multirow{2}{*}{$\begin{array}{l}\text { Particle dry deposition } \\
\text { Litterfall }\end{array}$} & Snowfall & Rainfall \\
\cline { 2 - 3 } Air-water exchange & Air-foliage exchange & Air-soil exchange \\
\cline { 2 - 2 } & Air-snowpack exchange & \\
\hline
\end{tabular}

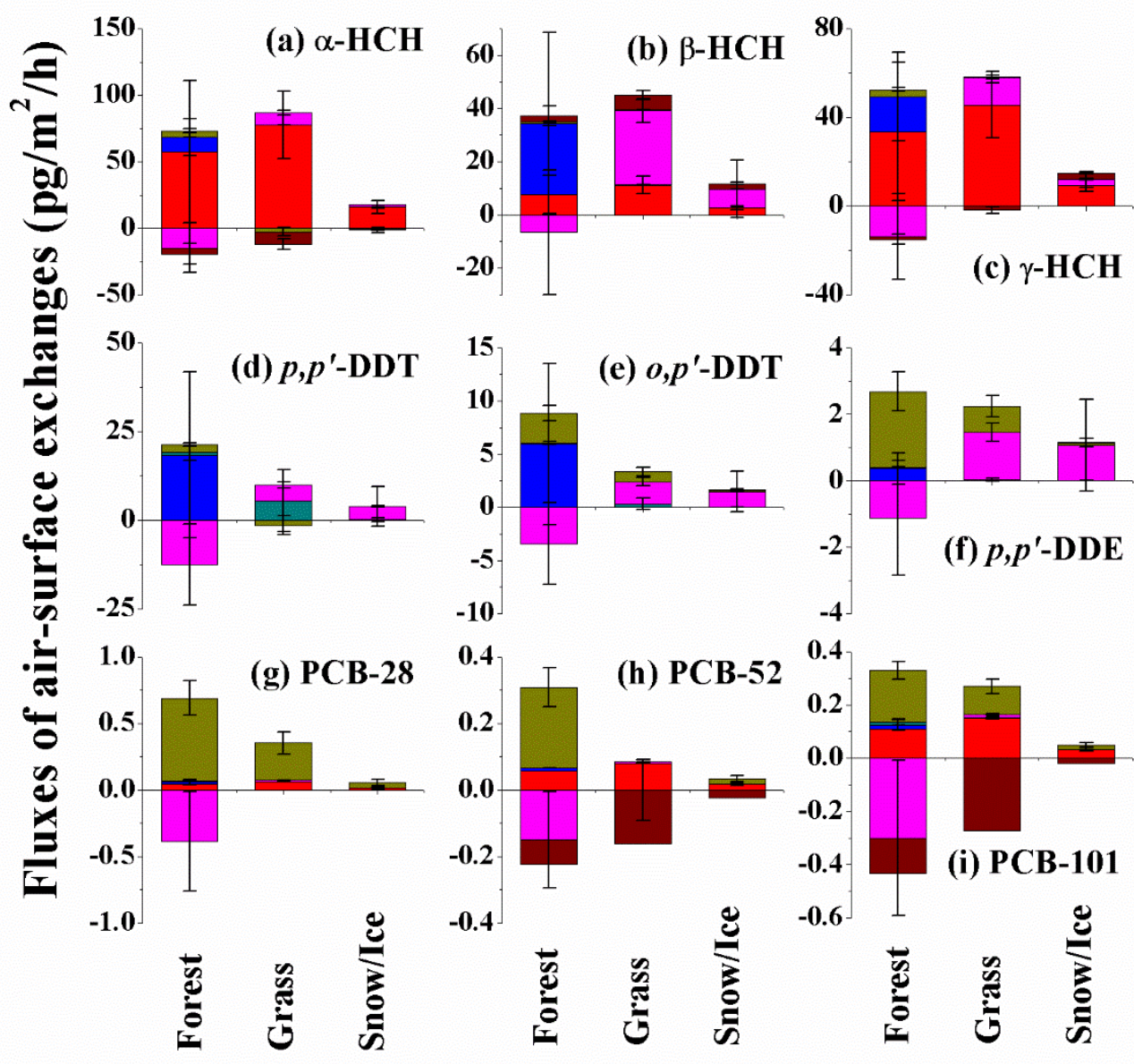

Figure S13. Exchange fluxes of target pollutants for the atmospheric processes simulated by the MCMPOP model (non-monsoon season, on the slopes of the Himalayas). Positive values indicate downward fluxes (deposition), while negative values stand for upward fluxes (evaporation from surface to air) 

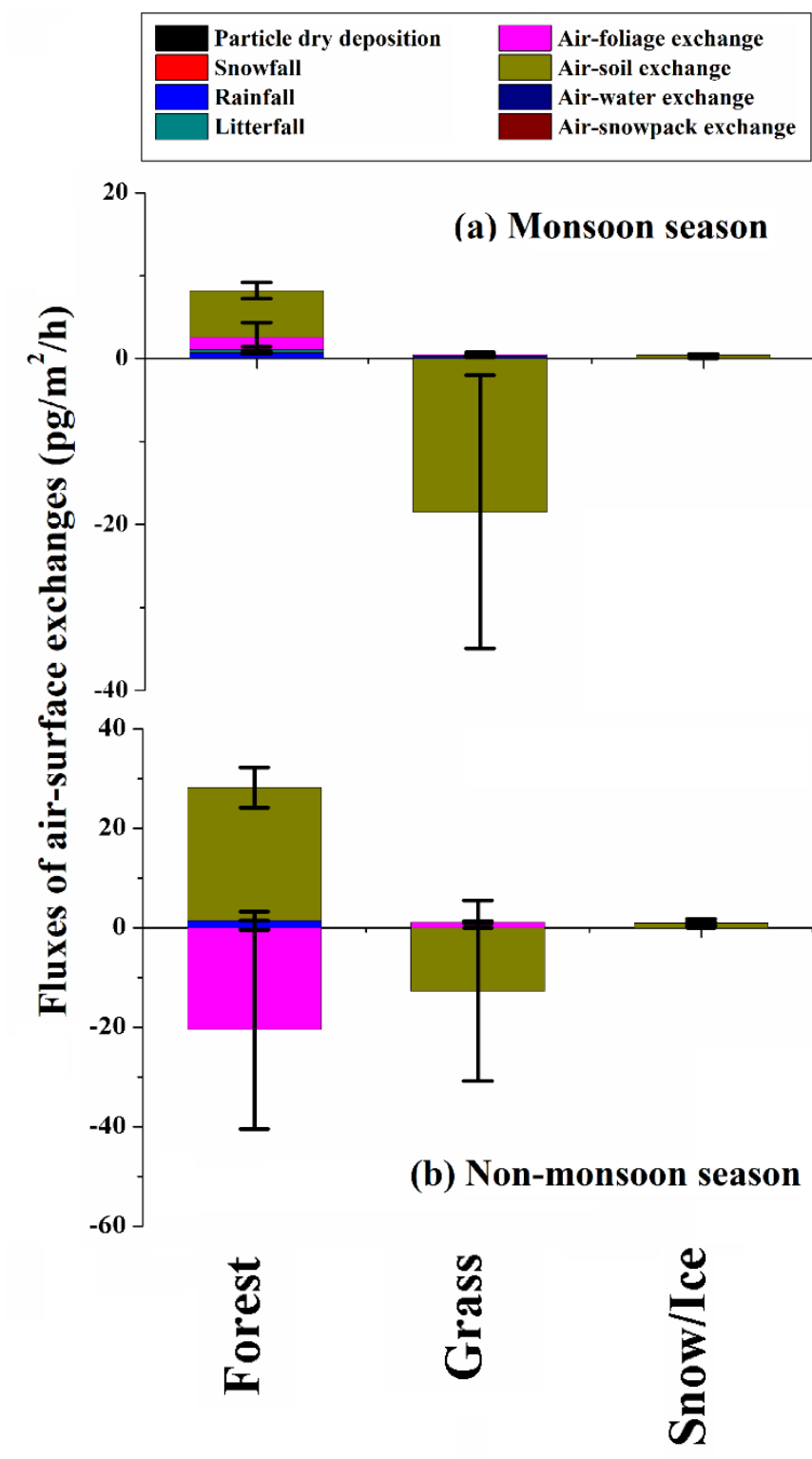

Figure S14. Changes in the fluxes of HCB along the slopes of the Himalayas in the (a) monsoon and (b) non-monsoon season 

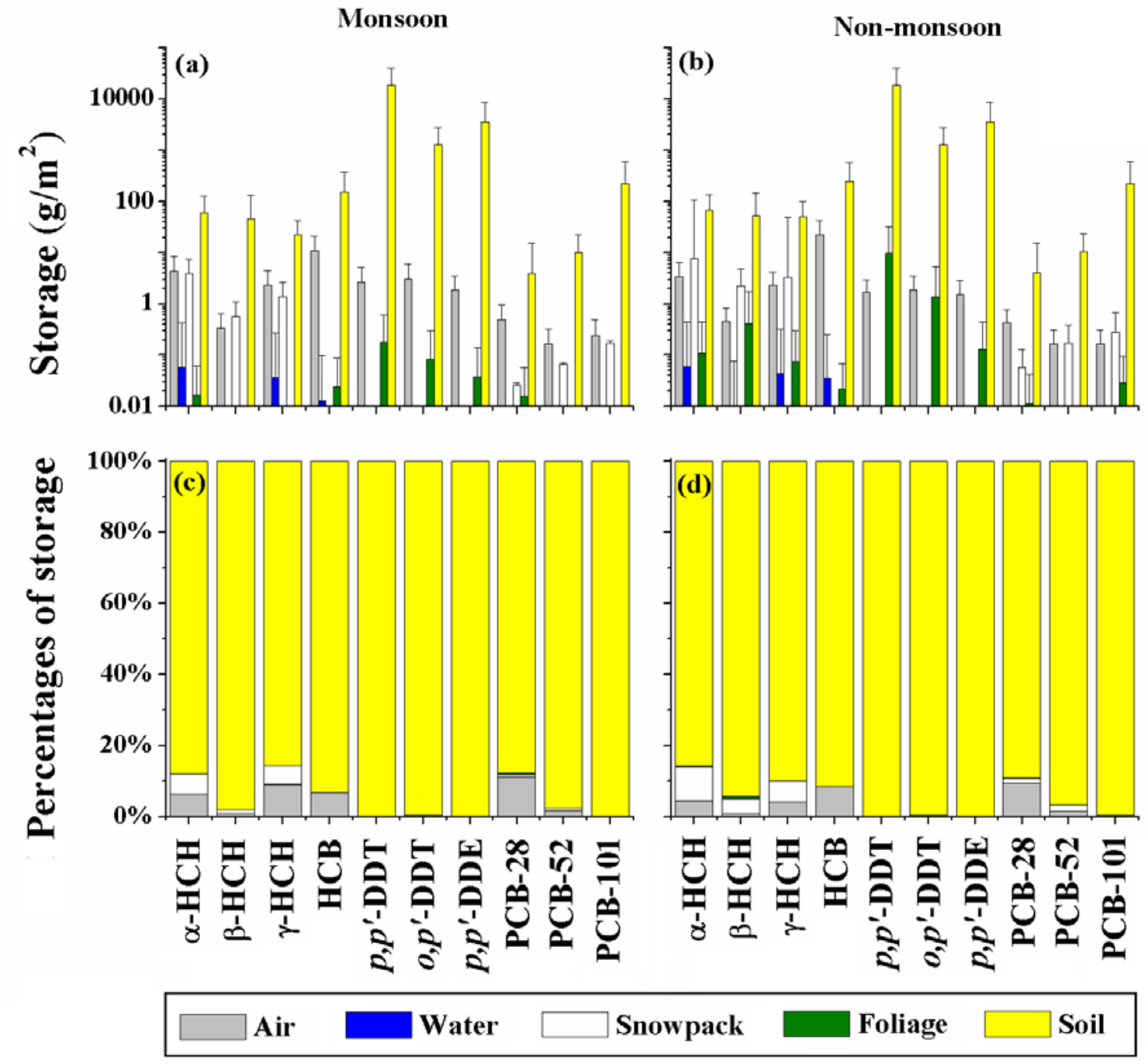

Figure S15. Average stored amounts of POPs (panel a and b) and percentages (panel c and d) in different matrices 

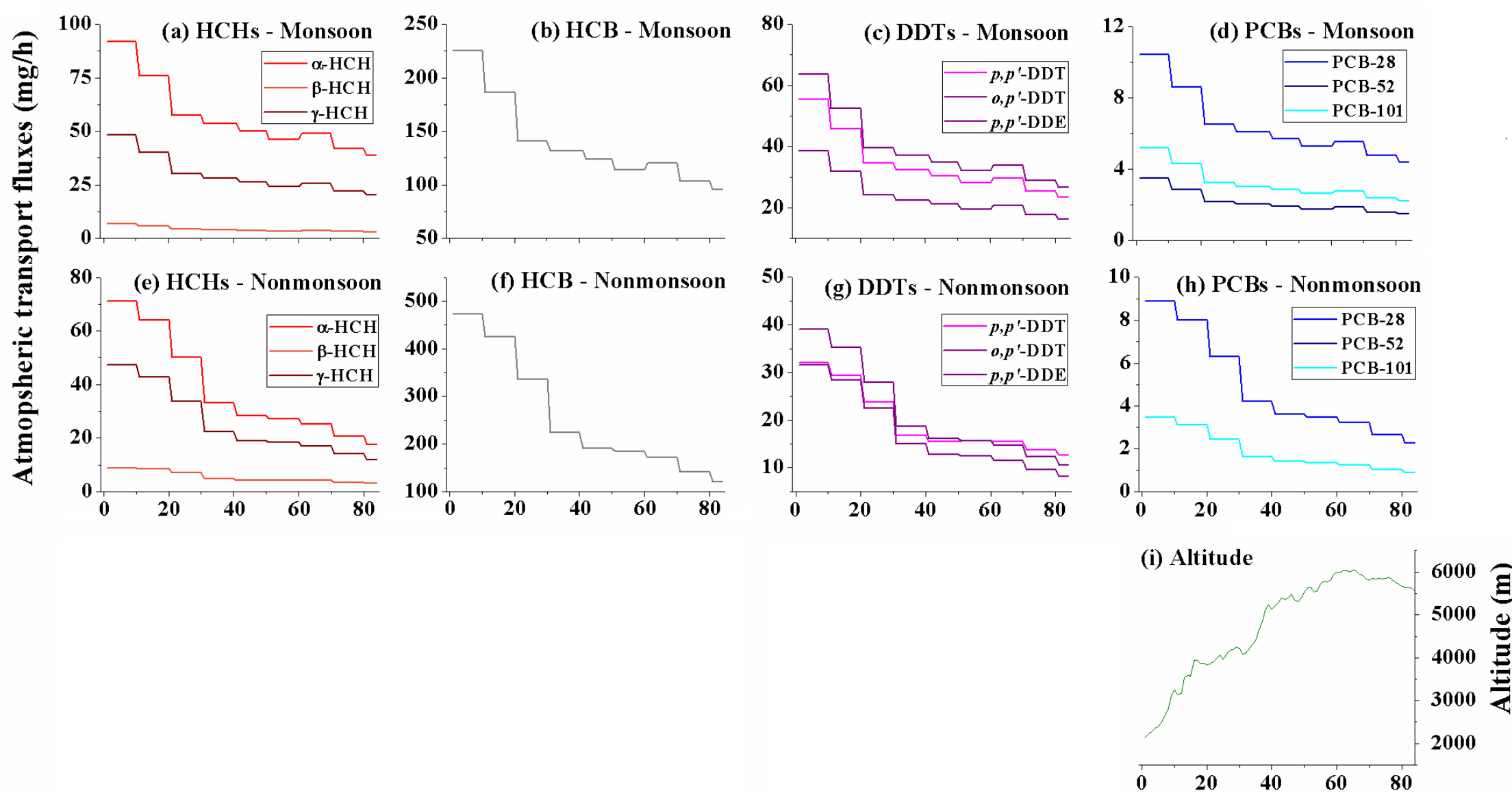

Distance from Syabru Besi (km)

Figure S16. The simulated atmospheric transport fluxes from one cell to the next upslope cell along the Himalayan slopes. The data were averaged in every ten cells. 


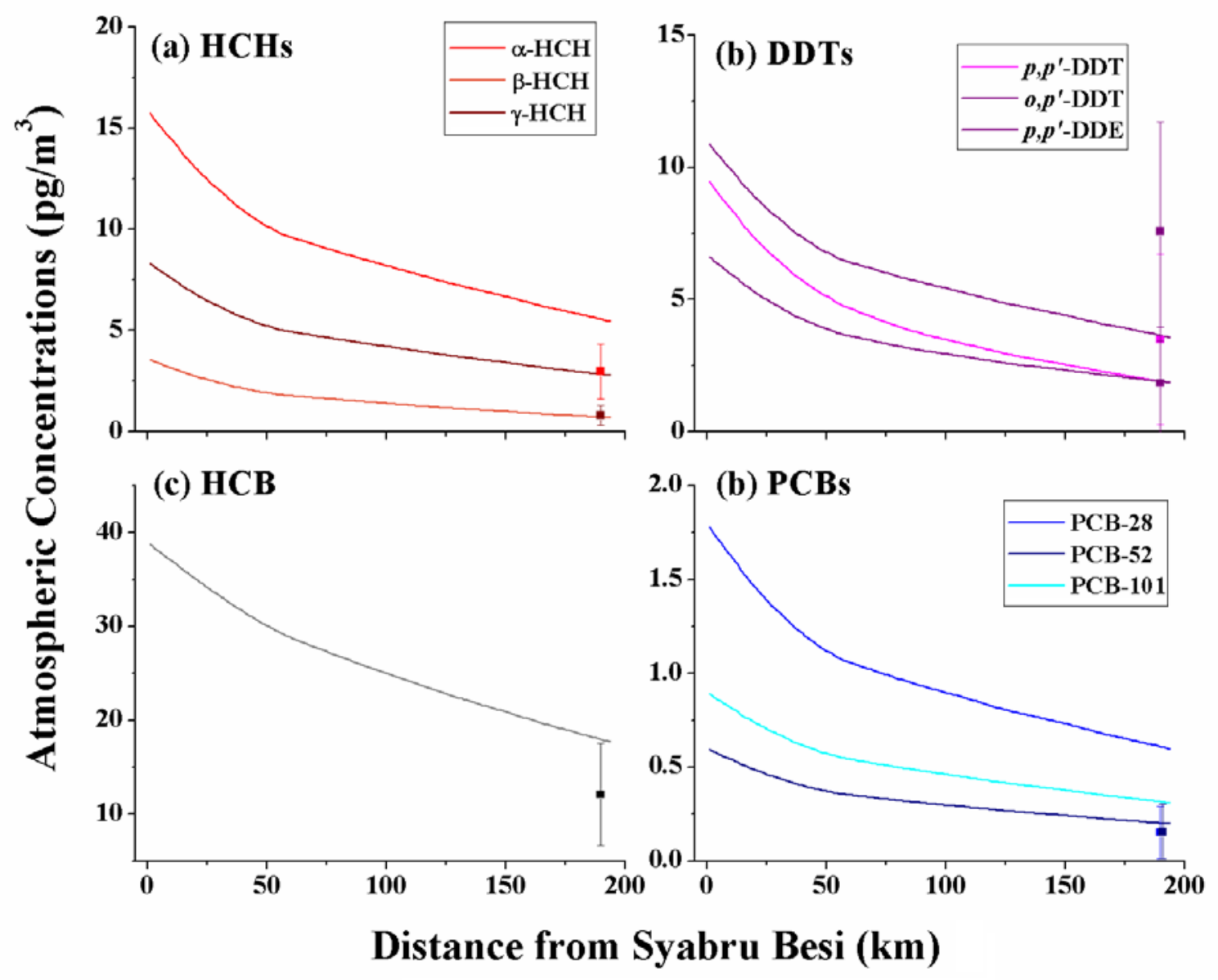

Figure S17. Simulated atmospheric concentrations of organochlorine compounds along the Gillon valley during the monsoon season. The dots are the observed concentrations of pollutants at Gillon (the northern slope of the Himalayas, Tibetan side). 


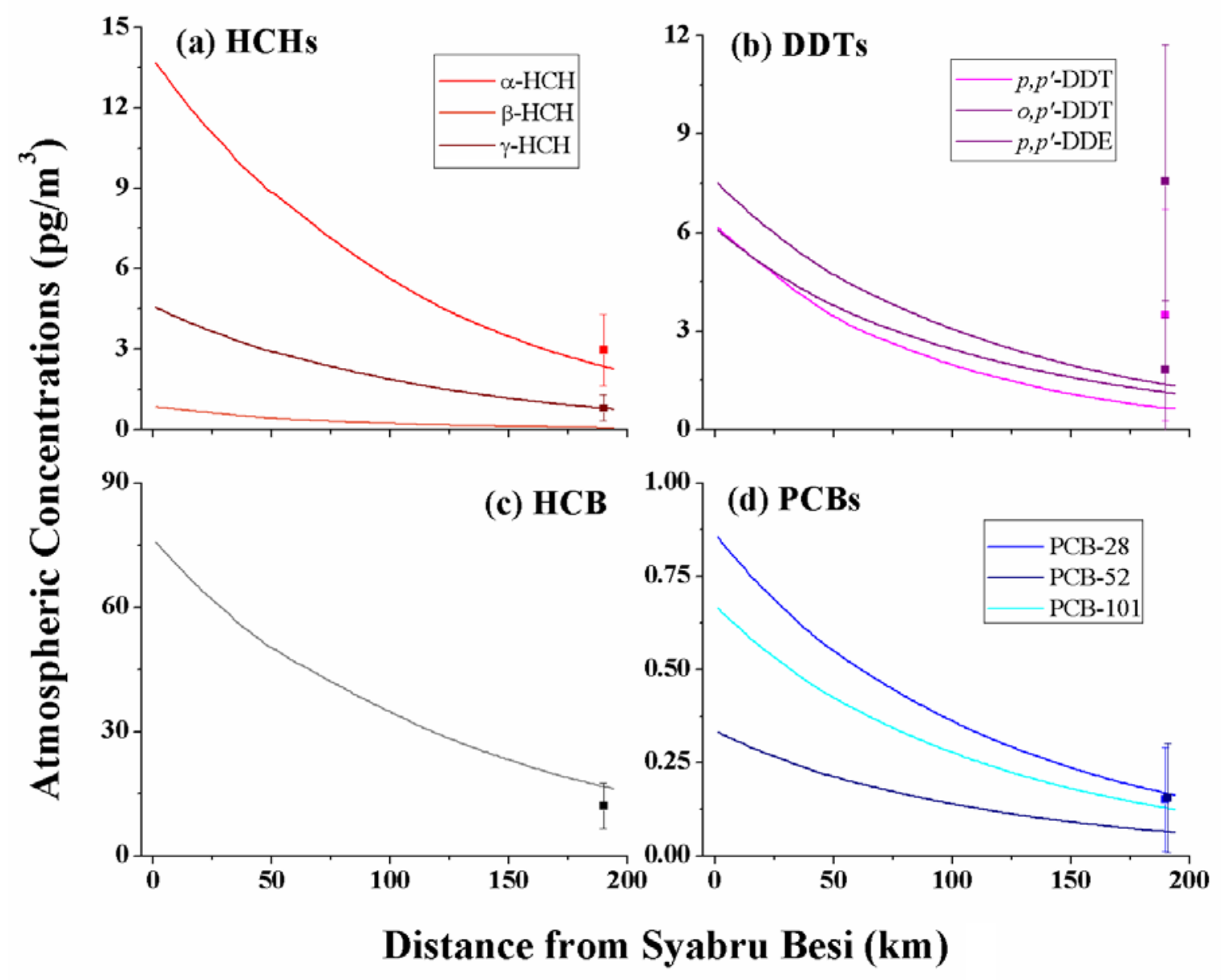

Figure S18. Simulated atmospheric concentrations of organochlorine compounds along the Gillon valley during the non-monsoon season. The dots are the observed concentrations of pollutants at Gillon (the northern slope of the Himalayas, Tibetan side). 


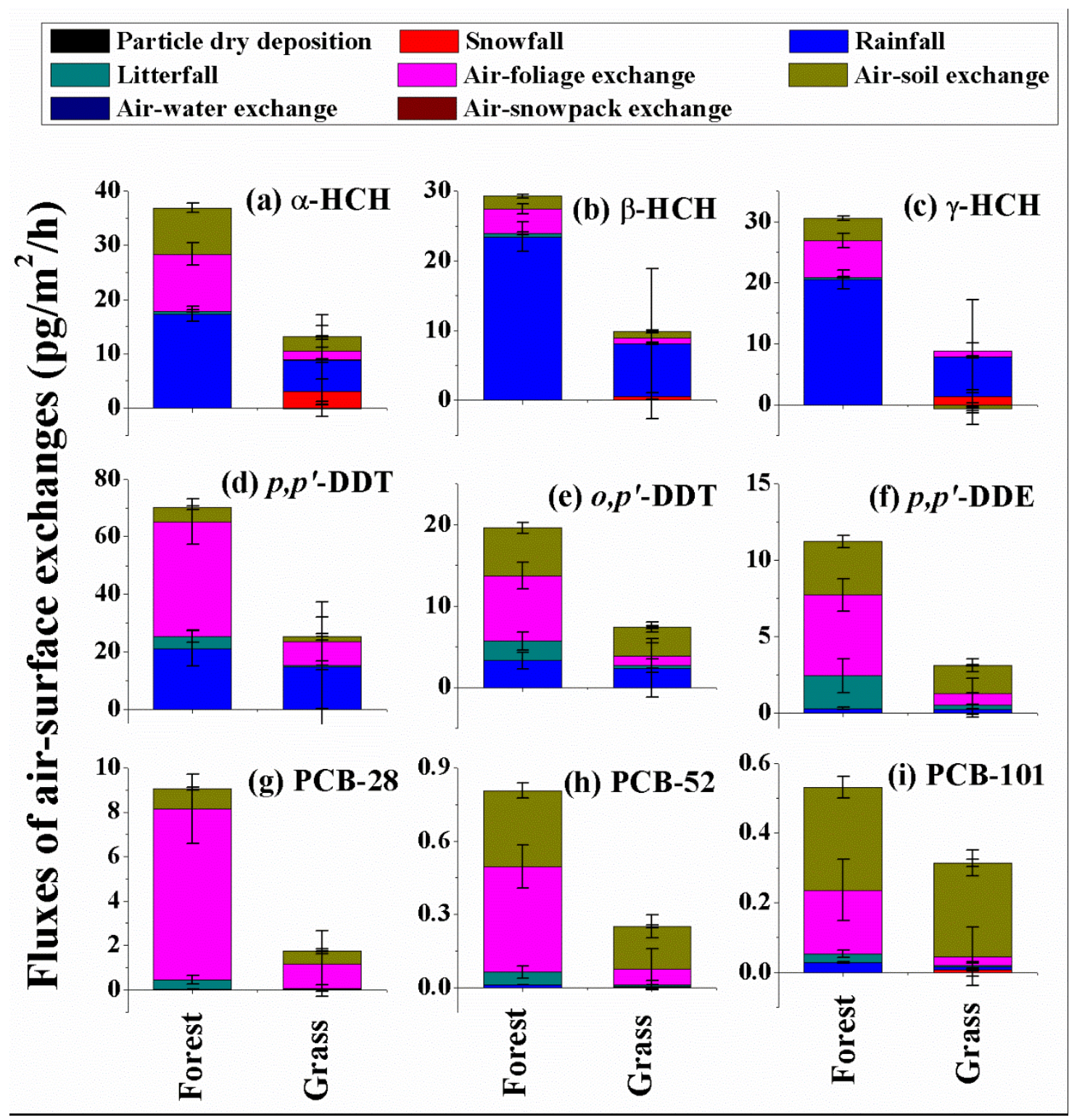

Figure S19. Exchange fluxes of target pollutants for the atmospheric processes simulated by the MCMPOP model (monsoon season, along the Gillon valley). Positive values indicate downward fluxes (deposition), while negative values indicate upward fluxes (evaporation from surface to air) 


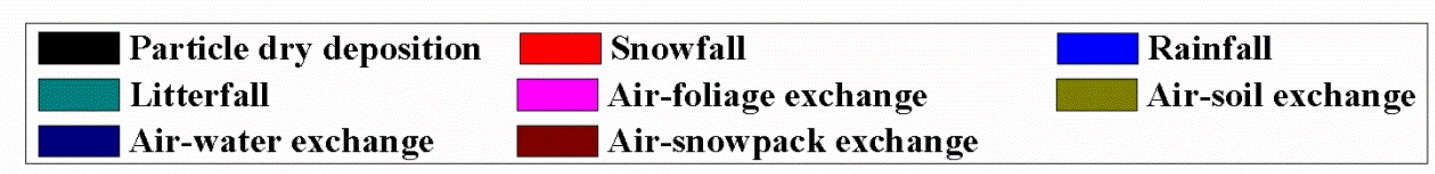

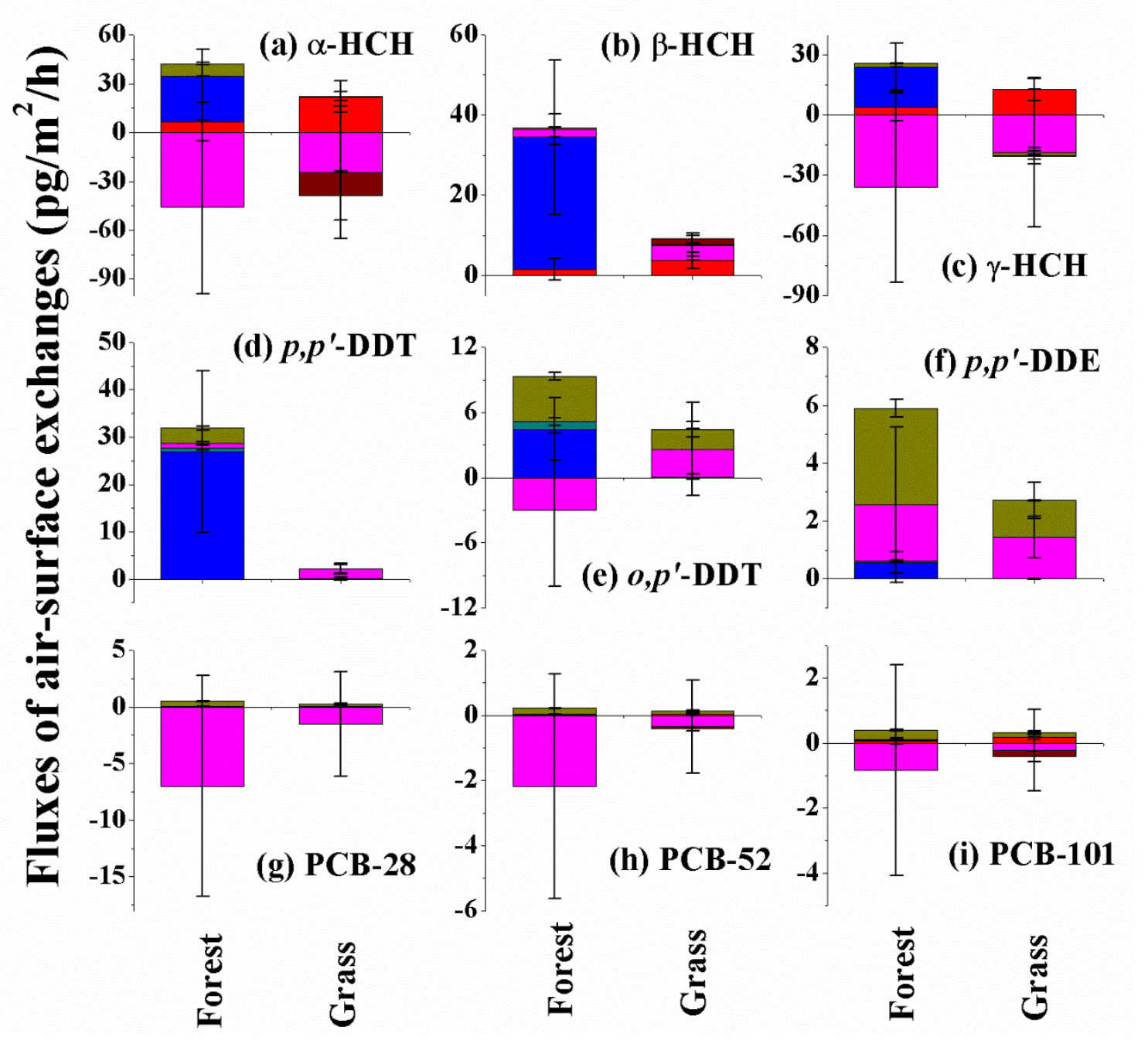

Figure S20. Exchange fluxes of target pollutants for the atmospheric processes simulated by the MCMPOP model (non-monsoon season, along the Gillon valley). Positive values indicate downward fluxes (deposition), while negative values indicate upward fluxes (evaporation from surface to air) 


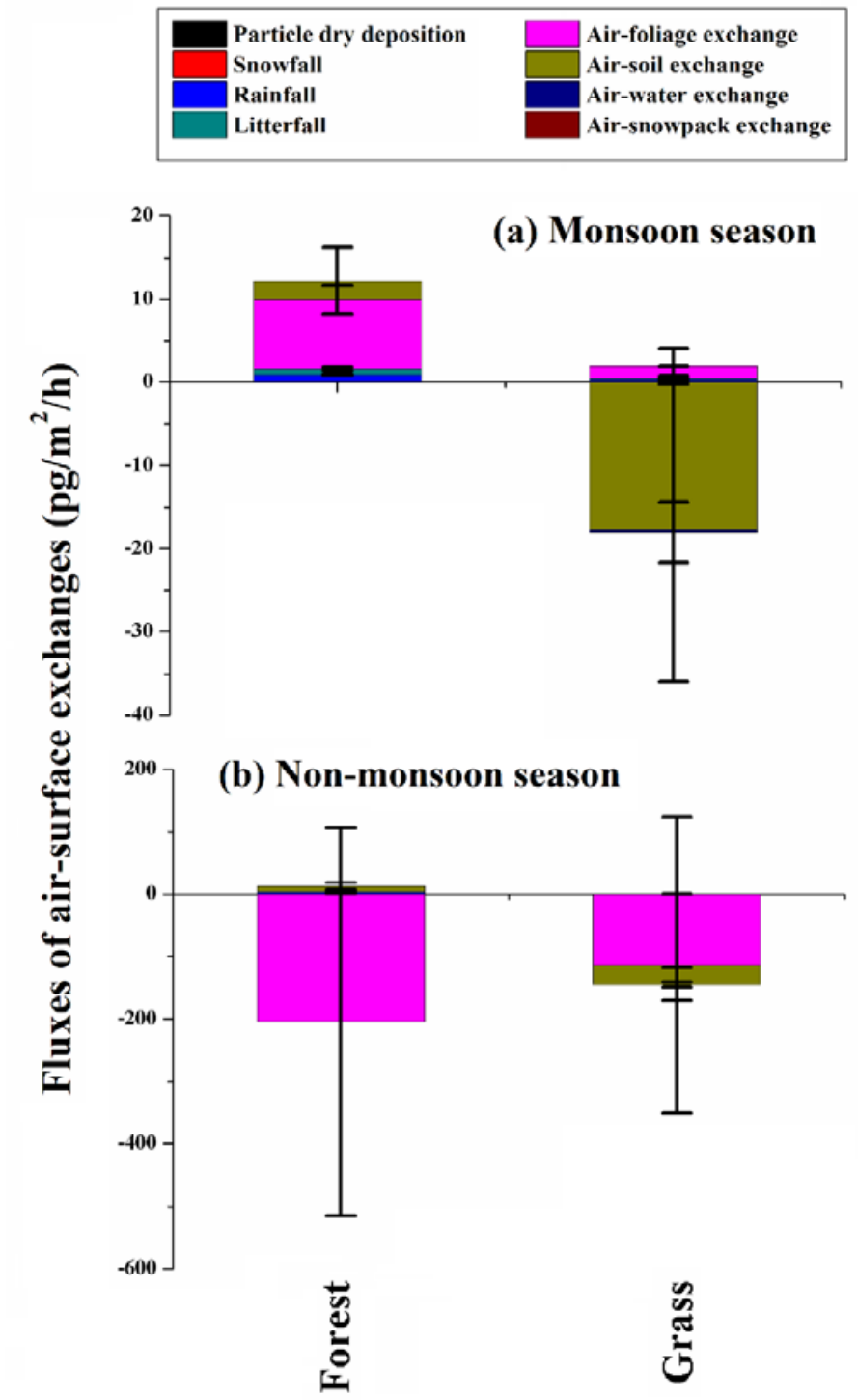

Figure S21. Changes in the fluxes of HCB along the Gillon valley in the (a) monsoon and (b) nonmonsoon season 


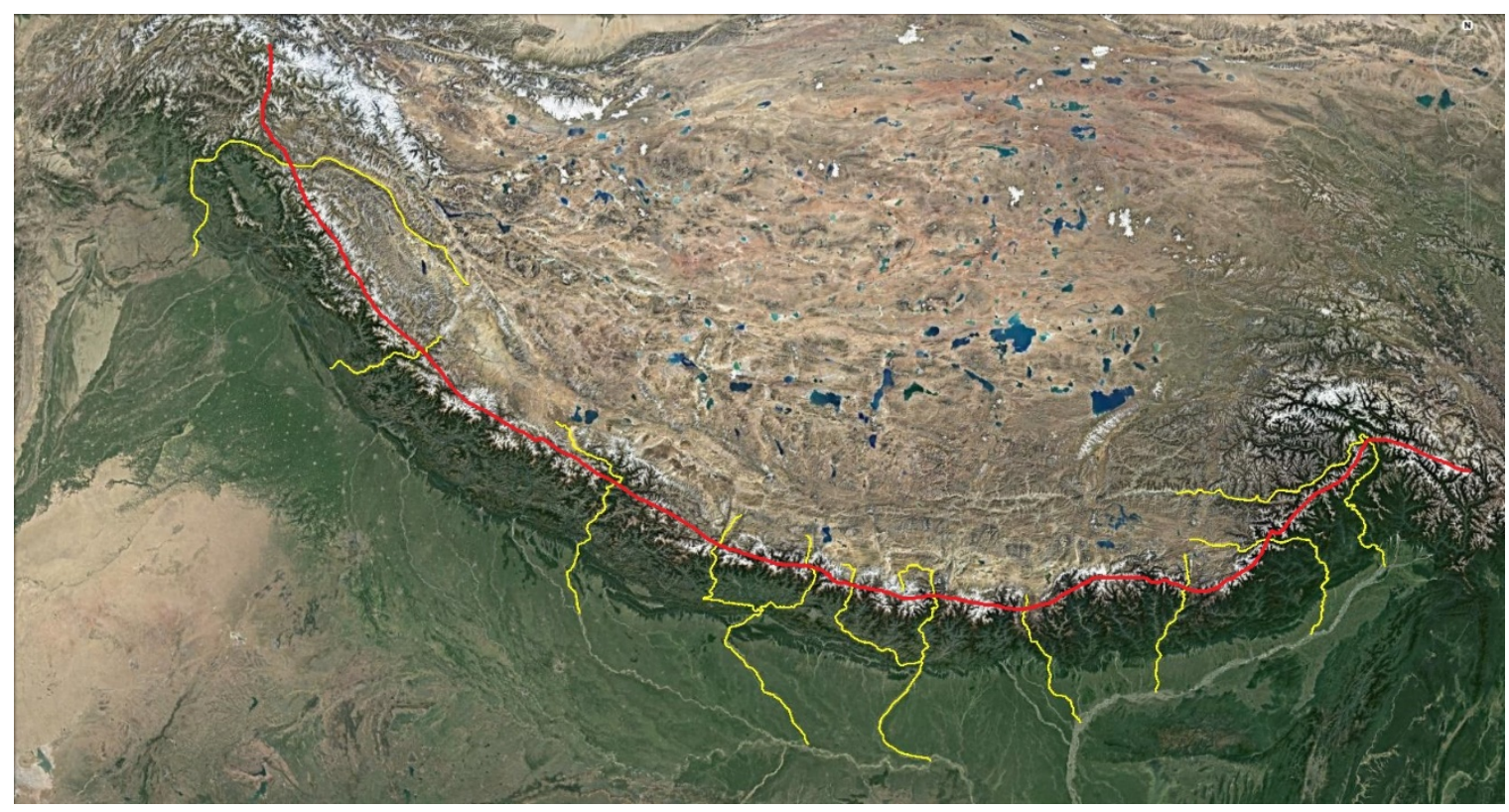

Figure S22. The mountain ridge (red line) and the main river valleys (yellow line) in the Himalayas. The map data is from Google Earth (Image Landsat/Copernicus).

Table S12. Details of the river valleys across the Himalayas

\begin{tabular}{lcc}
\hline Names of rivers in valleys & Drainage basin for rivers in valleys & Width of river valley (km) \\
\hline Yarlung Zangbo/Brahmaputra River & Brahmaputra River & 19 \\
Subansiri River & Brahmaputra River & 9 \\
Niangmujiangqu River & Brahmaputra River & 6 \\
Yadong River & Brahmaputra River & 9 \\
Pengqu River /Arun River & Ganges River & 8 \\
Boqu river /Kodari Khosi river & Ganges River & 6 \\
Gillon Zangbo/ Trishuli River & Ganges River & 12 \\
Mustang Khola & Ganges River & 9 \\
Majia Zangbo/Humla Karnali River & Ganges River & 8 \\
Dhauliganga River & Ganges River & 7 \\
Langqen Zangbo/ Indus River & Indus River & 8 \\
Total & & 101 \\
\hline
\end{tabular}




\section{Text S5. Estimation and uncertainties of the annual total transport of atmospheric POPs across the Himalayas.}

First, as Figure 5(b) shows, the simulated total transport flux of POPs across the Himalayas is 7.7 $\times 10^{-3}$ Giga-gram/year. However, uncertainties in our observations and MCMPOP model had been estimated (Text S4-2). Due to the assumptions and parameters that were used, the transport fluxes varied from $2 \times 10^{-3}$ to $2.2 \times 10^{-2}$ Giga-gram/year.

Second, some transport processes/pathways were neglected during upscaling. If we were to consider these pathways, the upper limits for the transport fluxes would be larger. For example:

- Some studies focused on the transport based on deep convention and air movement in stratosphere and suggested that stratospheric transport is an important pathway of air pollutants emitted in South Asia to the Tibetan Plateau or even dispersion globally. ${ }^{45}$, 46 However, our model only simulates the transport over the surface of the mountain, and the transport in higher layers is not considered.

- In the Himalayan regions (or the Southern Tibetan Plateau), westerly wind and Indian monsoon are the main atmospheric circulations controlling the climate and the transport of atmospheric components ${ }^{1}$. The MCMPOP model simulated the atmospheric transport of POPs mainly under the control of the Indian Monsoon, but the transport driven by westerly wind is missing.

Third, uncertainties associated with extrapolating values estimated for one slope and one valley to the entire length of the Himalayas are not considered:

- $\quad$ The altitude of the central Himalayas is higher than those of the western and eastern parts, and pollutant transport is blocked or delayed by the high altitude comparing to the transport at the western and/or eastern Himalayas ${ }^{47,48}$. Therefore, our estimation using the data in the central Himalayas will underestimate the transport fluxes.

- The height of model cells is $1 \mathrm{~km}$, assuming that this value represent the average height of the atmospheric boundary layer (ABL) in mountain regions. Actually, the ABL height in mountain regions can change from place to place, which may lead to uncertainty in the flux estimation.

- Only river valleys that cut through the mountain were considered in the flux estimation, while numerous small mountain valleys also act as channels for POPs transport ${ }^{49,50}$, which is ignored in the model. 
- Emission sources/intensity in Nepal were used to run our model. However, those of Pakistan in northwest and Bangladesh and southeast of Himalayas were reported to be greater than in $\mathrm{Kathmandu}^{51}$. MCMPOP model might underestimate the total influence of south Asian emission to the Himalayan Mountain.

Overall, based on all-above estimations, the total amount of POPs undergoing trans-Himalayas transport can be expected to fall within a range of two order of magnitudes $\left(2 \times 10^{-3}-1 \times 10^{-1}\right.$ Gigagram per year). 
Table S13. The contributors for the field and data analysis work in this study

\begin{tabular}{|c|c|c|c|}
\hline Name & Nationality & Affiliation & Contribution \\
\hline Tandong Yao & Chinese & Institute of Tibetan Plateau Research, CAS & Group leader who gave suggestions on Nepali studies \\
\hline Lide Tian & Chinese & $\begin{array}{l}\text { Institute of Tibetan Plateau Research, CAS; } \\
\text { Yunnan University }\end{array}$ & $\begin{array}{l}\text { Organizer of a scientific team which set up the XAD- } \\
\text { PASs and contributor of meteorological data }\end{array}$ \\
\hline Wusheng Yu & Chinese & Institute of Tibetan Plateau Research, CAS & Organizer of the scientific teams to Langtang region \\
\hline Dorothea Stumm & Swiss & $\begin{array}{l}\text { International Centre for Integrated Mountain } \\
\text { Development (ICIMOD) }\end{array}$ & $\begin{array}{l}\text { Organizer of the scientific teams to Langtang region } \\
\text { and contributor of meteorological data }\end{array}$ \\
\hline Sharad P. Joshi & Nepalese & $\begin{array}{l}\text { International Centre for Integrated Mountain } \\
\text { Development (ICIMOD) }\end{array}$ & Organizer of the scientific teams to Langtang region \\
\hline Lochan P. Devkota & Nepalese & $\begin{array}{l}\text { Central Department of Hydrology and Meteorology } \\
\text { (CDHM), Tribhuvan University; } \\
\text { Kathmandu Center for Research and Education, } \\
\text { CAS-TU }\end{array}$ & Helper for the sampling in Kathmandu \\
\hline Shenghai Li & Chinese & Institute of Tibetan Plateau Research, CAS & Team mate in scientific teams \\
\hline Weicai Wang & Chinese & Institute of Tibetan Plateau Research, CAS & Team mate in scientific teams \\
\hline Dambaru Ballab Kattel & Nepalese & Institute of Tibetan Plateau Research, CAS & Helper for communicating with local people \\
\hline Tek Bahadur Chhetri & Nepalese & Tribhuvan University & Helper for communicating with local people \\
\hline Jiule Li & Chinese & Institute of Tibetan Plateau Research, CAS & Setting up the XAD-PASs in Langtang region \\
\hline Xiaoxin Yang & Chinese & Institute of Tibetan Plateau Research, CAS & Cooperator in a team to lowland of Nepal \\
\hline Sunil Acharya & Nepalese & Institute of Tibetan Plateau Research, CAS & Helper for communicating with local people \\
\hline Rong Wen & Chinese & Institute of Tibetan Plateau Research, CAS & Team mate in a scientific team to Langtang region \\
\hline Zhongyin Cai & Chinese & Institute of Tibetan Plateau Research, CAS & Team mate in a scientific team to Langtang region \\
\hline Junmeng Zhao & Chinese & Institute of Tibetan Plateau Research, CAS & Organizer in a scientific team to lowland of Nepal \\
\hline J P Lama Sherpa & Nepalese & Guides of All Seasons Trek & Guide for high mountain sampling \\
\hline
\end{tabular}




\begin{tabular}{|c|c|c|c|}
\hline Kipa Sherpa & Nepalese & Guides of All Seasons Trek & Guide for high mountain sampling \\
\hline Dhananjay Regmi & Nepalese & Nepal Geographical Society & Helper for sampling \\
\hline Pa Sang and his family & Nepalese & Meteorological station in Kyanjin Gumba & Taking care of the PASs in Kyanjin Gumba \\
\hline Bishnu Kharel & Nepalese & Meteorological station at Simara airport & Taking care of the PASs in Simara \\
\hline Amrit Aryal & Nepalese & & Taking care of the PASs in Hetauda \\
\hline Rijan Bhakta Kayastha & Nepalese & Kathmandu University & Team mate in a scientific team to Langtang region \\
\hline Sanjay Gurung & Nepalese & Kathmandu University & Team mate in a scientific team to Langtang region \\
\hline Binod Dawadi & Nepalese & Tribhuvan University & Taking care of the PASs in Kathmandu \\
\hline Chuanfei Wang & Chinese & Institute of Tibetan Plateau Research, CAS & Resin preparation and sample analysis \\
\hline Hang Zhou & Chinese & Descarters Labs, USA & Coordinate transformation of remote sensing data \\
\hline Jiao Ren & Chinese & Shanxi University of Finance \& Economics & Adviser for fugacity model \\
\hline Yun Qian & American & $\begin{array}{l}\text { Atmospheric Sciences and Global Change Division, } \\
\text { Pacific Northwest National Laboratory (PNNL) }\end{array}$ & Adviser for atmospheric transport model \\
\hline Rudong Zhang & Chinese & $\begin{array}{l}\text { School of Atmospheric Sciences, Nanjing } \\
\text { University; } \\
\text { Atmospheric Sciences and Global Change Division, } \\
\text { Pacific Northwest National Laboratory (PNNL) }\end{array}$ & Adviser for atmospheric transport model \\
\hline Weiming Ma & Chinese & University of California, Los Angeles & Adviser for atmospheric transport model \\
\hline
\end{tabular}




\section{Cited References}

(1) Wang, X.; Ren, J.; Gong, P.; Wang, C.; Xue, Y.; Yao, T.; Lohmann, R., Spatial distribution of the persistent organic pollutants across the Tibetan Plateau and its linkage with the climate systems: a 5-year air monitoring study. Atmos. Chem. Phys. 2016, 16 (11), 6901-6911.

(2) Pokhrel, B.; Gong, P.; Wang, X.; Khanal, S. N.; Ren, J.; Wang, C.; Gao, S.; Yao, T., Atmospheric organochlorine pesticides and polychlorinated biphenyls in urban areas of Nepal: spatial variation, sources, temporal trends and long range transport potential. Atmos. Chem. Phys. 2018, 18, 1325-1336.

(3) Dong, Z.; Kang, S.; Guo, J.; Zhang, Q.; Wang, X.; Qin, D., Composition and mixing states of brown haze particle over the Himalayas along two transboundary south-north transects. Atmos. Environ. 2017, 156, 24-35.

(4) Shrestha, K. B. Treeline and vegetation dynamics in respone to environmental changes in Nepal, the central Himalaya. [PhD thesis]. University of Bergen, Norway, 2013.

(5) Li, S.; Yao, T.; Tian, L.; Wang, P., Seasonal transition characteristics of the westerly jet: Study based on field observations at an altitude of $6900 \mathrm{~m}$ on the Mt. Xixiabangma Dasuopu glacier. Chin. Sci. Bull. 2011, 56 (18), 1912-1920.

(6) Stein, A.F.; Draxler, R.R; Rolph, G.D.; Stunder, B.J.B.; Cohen, M.D.; Ngan, F., NOAA's HYSPLIT atmospheric transport and dispersion modeling system. Bull. Amer. Meteor. Soc. 2015, 96, 2059-2077.

(7) Mackay, D. Multimedia Environmental Models: The Fugacity Approach (Second Edition);. Lewis Publishers: 2001.

(8) Wang, X.P.; Gong, P.; Yao, T.D.; Jones, K. C., Passive Air Sampling of Organochlorine Pesticides, Polychlorinated Biphenyls, and Polybrominated Diphenyl Ethers Across the Tibetan Plateau. Environ. Sci. Technol. 2010, 44 (8), 2988-2993.

(9) Li, Y.; Xu, X.; Zhang, M.; Xu, Y., Wind tunnel test and numerical simulation of wind characteristics at a bridge site in mountainous terrain. Adv. Struct. Eng. 2017, 20 (8), 12231231.

(10) Gong, P.; Wang, X.P.; Li, S.H.; Yu, W.S.; Li, J.L.; Kattel, D. B.; Wang, W.C.; Devkota, L. P.; Yao, T.D.; Joswiak, D. R., Atmospheric transport and accumulation of organochlorine compounds on the southern slopes of the Himalayas, Nepal. Environ. Pollut. 2014, 192, 4451.

(11) Wang, X.P.; Sheng, J.J.; Gong, P.; Xue, Y.G.; Yao, T.D.; Jones, K. C., Persistent organic pollutants in the Tibetan surface soil: Spatial distribution, air-soil exchange and implications for global cycling. Environ. Pollut. 2012, 170 (0), 145-151.

(12) Wang, X.P.; Xu, B.Q.; Kang, S.C.; Cong, Z.Y.; Yao, T.D., The historical residue trends of DDT, hexachlorocyclohexanes and polycyclic aromatic hydrocarbons in an ice core from Mt. Everest, central Himalayas, China. Atmos. Environ. 2008, 42 (27), 66119-6709.

(13) Wania, F.; McLachlan, M. S., Estimating the influence of forests on the overall fate of semivolatile organic compounds using a multimedia fate model. Environ. Sci. Technol. 2001, 35 (3), 582-590.

(14) Wania, F.; Persson, J.; Guardo, A. D.; McLachlan, M. S. CoZMo-POP: A fugacity-based multi-compartmental mass balance model of the fate of persistent organic pollutants in the coastal zone; WECC Wania Environmental Chemists Corp.: Toronto, 2000. 
(15) Daly, G. L.; Wania, F., Simulating the influence of snow on the fate of organic compounds. Environ. Sci. Technol. 2004, 38 (15), 4176-4186.

(16) Lei, Y. D.; Wania, F., Is rain or snow a more efficient scavenger of organic chemicals? Atmos. Environ. 2004, 38 (22), 3557-3571.

(17) Wania, F.; Breivik, K.; Persson, N. J.; McLachlan, M. S., CoZMo-POP 2 - A fugacity-based dynamic multi-compartmental mass balance model of the fate of persistent organic pollutants. Environ. Modell. Softw. 2006, 21 (6), 868-884.

(18) Westgate, J. N.; Wania, F., Model-based exploration of the drivers of mountain cold-trapping in soil. Environ. Sci. -Process Impacts 2013, 15 (12), 2220-2232.

(19) Xu, Y.; Tian, C.; Ma, J.; Zhang, G.; Li, Y.-F.; Ming, L.; Li, J.; Chen, Y.; Tang, J., Assessing Environmental Fate of $\beta$-HCH in Asian Soil and Association with Environmental Factors. Environ. Sci. Technol. 2012, 46 (17), 9525-9532.

(20) Abraham, M. H.; Enomoto, K.; Clarke, E. D.; Sexton, G., Hydrogen bond basicity of the chlorogroup; Hexachlorocyclohexanes as strong hydrogen bond bases. J. Org. Chem. 2002, 67 (14), 4782-4786.

(21) Xiao, H.; Li, N. Q.; Wania, F., Compilation, evaluation, and selection of physical-chemical property data for alpha-, beta-, and gamma-hexachlorocyclohexane. J. Chem. Eng. Data 2004, 49 (2), 173-185.

(22) Jantunen, L. M.; Bidleman, T. F., Henry's law constants for hexachlorobenzene, p,p'-DDE and components of technical chlordane and estimates of gas exchange for Lake Ontario. Chemosphere 2006, 62 (10), 1689-1696.

(23) Cetina, B.; Ozer, S.; Sofuoglu, A.; Odabasi, M., Determination of Henry's law constants of organochlorine pesticides in deionized and saline water as a function of temperature (vol 40, pg 4538, 2006). Atmos. Environ. 2006, 40 (40), 8096-8096.

(24) Meylan, W. M.; Howard, P. H., Estimating octanol-air partition coefficients with octanolwater partition coefficients and Henry's law constants. Chemosphere 2005, 61 (5), 640-644.

(25) Li, N.; Wania, F.; Lei, Y.D.; Daly, G.L., A comprehensive and critical compilation, evaluation and selection of physical chemical property data for selected polychlorinated biphenyls. $J$. Phys. Chem. Ref. Data 2003, 32, 1535-1590.

(26) Shen, L.; Wania, F., Compilation, evaluation, and selection of physical-chemical property data for organochlorine pesticides. J. Chem. Eng. Data 2005, 50 (3), 742-768.

(27) Shoeib, M.; Harner, T., Using measured octanol-air partition coefficients to explain environmental partitioning of organochlorine pesticides. Environ. Toxicol. Chem. 2002, 21 (5), 984-990.

(28) Li, L.; Liu, J.; Hu, J., Global inventory, long-range transport and environmental distribution of dicofol. Environ. Sci. Technol. 2015, 49 (1), 212-222.

(29) Beyer, A.; Wania, F.; Gouin, T.; Mackay, D.; Matthies, M., Selecting internally consistent physicochemical properties of organic compounds. Environ. Toxicol. Chem. 2002, 21 (5), 941953.

(30) Paasivirta, J.; Sinkkonen, S. I., Environmentally relevant properties of all 209 polychlorinated biphenyl congeners for modeling their fate in different natural and climatic conditions. $J$. Chem. Eng. Data 2009, 54 (4), 1189-1213.

(31) Aronson, D.; Printup, H.; Shuler, K.; Howard, P., Chemical fate half-lives for toxics release inventory (TRI) chemicals. In U.S. EPA, Washington DC, 1998. 
(32) Wania, F.; Daly, G.L., Estimating the contribution of degradation in air and deposition to the deep sea to the global loss of PCBs. Atmos. Environ. 2002, 36, 5581-5593.

(33) Roth, C. M.; Goss, K.-U.; Schwarzenbach, R. P., Sorption of diverse organic vapors to snow. Environ. Sci. Technol. 2004, 38 (15), 4078-4084.

(34) Cousins, I. T.; Mackay, D.; Jones, K. C., Measuring and modelling the vertical distribution of semivolatile organic compounds in soils. II: Model development. Chemosphere 1999, 39 (14), 2519-2534.

(35) Ren, J.; Wang, X.; Wang, C.; Gong, P.; Yao, T., Atmospheric processes of organic pollutants over a remote lake on the central Tibetan Plateau: implications for regional cycling. Atmos. Chem. Phys. 2017, 17 (2), 1401-1415.

(36) Wan, X.; Kang, S.; Li, Q.; Rupakheti, D.; Zhang, Q.; Guo, J.; Chen, P.; Tripathee, L.; Rupakheti, M.; Panday, A. K.; Wang, W.; Kawamura, K.; Gao, S.; Wu, G.; Cong, Z., Organic molecular tracers in the atmospheric aerosols from Lumbini, Nepal, in the northern IndoGangetic Plain: influence of biomass burning. Atmos. Chem. Phys. 2017, 17 (14), 8867-8885.

(37) Prinn, R. G.; Weiss, R. F.; Miller, B. R.; Huang, J.; Alyea, F. N.; Cunnold, D. M.; Fraser, P. J.; Hartley, D. E.; Simmonds, P. G., Atmospheric trends and lifetime of $\mathrm{CH}_{3} \mathrm{CCl}_{3}$ and global OH concentrations. Science 1995, 269 (5221), 187-192.

(38) Stocker, J.; Scheringer, M.; Wegmann, F.; Hungerbuhler, K., Modeling the effect of snow and ice on the global environmental fate and long-range transport potential of semivolatile organic compounds. Environ. Sci. Technol. 2007, 41 (17), 6192-6198.

(39) Herbert, B. M. J.; Halsall, C. J.; Jones, K. C.; Kallenborn, R., Field investigation into the diffusion of semi-volatile organic compounds into fresh and aged snow. Atmos. Environ. 2006, 40 (8), 1385-1393.

(40) Nizzetto, L.; Jarvis, A.; Brivio, P. A.; Jones, K. C.; Di Guardo, A., Seasonality of the air-forest canopy exchange of persistent organic pollutants. Environ. Sci. Technol. 2008, 42 (23), 87788783.

(41) Atkinson, R.; Arey, J., Atmospheric degradation of volatile organic compounds. Chem. Rev. 2003, 103 (12), 4605-4638.

(42) Harner, T.; Bidleman, T. F., Measurements of octanol-air partition coefficients for polychlorinated biphenyls. J. Chem. Eng. Data 1996, 41 (4), 895-899.

(43) Lei, Y. D.; Wania, F.; Mathers, D.; Mabury, S. A., Determination of vapor pressures, octanolair, and water-air partition coefficients for polyfluorinated sulfonamide, sulfonamidoethanols, and telomer alcohols. J. Chem. Eng. Data 2004, 49 (4), 1013-1022.

(44) Su, L.; Yuan, Z.; Fung, J. C. H.; Lau, A. K. H., A comparison of HYSPLIT backward trajectories generated from two GDAS datasets. Sci. Total Environ. 2015, 506-507, 527-537.

(45) Fu, R.; Hu, Y.; Wright, J. S.; Jiang, J. H.; Dickinson, R. E.; Chen, M.; Filipiak, M.; Read, W. G.; Waters, J. W.; Wu, D. L., Short circuit of water vapor and polluted air to the global stratosphere by convective transport over the Tibetan Plateau. Proc. Natl. Acad. Sci. U. S. A. 2006, 103 (15), 5664-5669.

(46) Lelieveld, J.; Bourtsoukidis, E.; Brühl, C.; Fischer, H.; Fuchs, H.; Harder, H.; Hofzumahaus, A.; Holland, F.; Marno, D.; Neumaier, M.; Pozzer, A.; Schlager, H.; Williams, J.; Zahn, A.; Ziereis, H., The South Asian monsoon-Pollution pump and purifier. Science 2018, 361 (6399), 270-273. 
(47) Gong, P.; Wang, X.P.; Xue Y.G.; Sheng, J.J.; Gao, S.P.; Tian L.D.; Yao, T.D., Influence of atmospheric circulation on the long-range transport of organochlorine pesiticides to the western Tibetan Plateau. Atmos. Res. 2015, 166, 157-164.

(48) Gong, P.; Wang, X.; Sheng, J.; Wang, H.; Yuan, X.; He, Y.; Qian, Y.; Yao, T., Seasonal variations and sources of atmospheric polycyclic aromatic hydrocarbons and organochlorine compounds in a high-altitude city: evidence from four-year observations. Environ. Pollut. 2018, 233, 1188-1197.

(49) Cong, Z.; Kawamura, K.; Kang S.; Fu, P., Penetration of biomass-burning emissions from South Asia through the Himalayas: new insights from atmospheric organic acids. Sci. Rep. 2015, 5, 9580.

(50) Bonasoni, P.; Laj, P.; Marinoni, A.; Sprenger, M.; Angelini, F.; Arduini, J.; Bonafe, U.; Calzolari, F.; Colombo, T.; Decesari, S.; Di Biagio, C.; di Sarra, A.G.; Evengelisti, F.; Duchi, R.; Facchini MC.; Fuzzi, S.; Gobbi, G.P.; Maione, M.; Panday, A.; Roccato, F.; Sellegri, K.; Venzac, H.; Verza, GP.; Villani, P.; Vuillermoz, E.; Cristofanelli, P., Atmospheric brown clouds in the Himalayas: first two years of continuous observations at the Nepal Climate Observatory - Pyramid (5079 m). Atmos. Chem. Phys. 2010, 10, 7515-7531.

(51) Ali, U.; Syed, J.H.; Malik, R.N.; Katsoyiannis, A.; Li, J.; Zhang, G.; Jones, K.C., Organochlorine pesticides (OCPs) in South Asian region: a review. Sci. Total Environ. 2014, 476-477, 705-717. 